\title{
Verdedigingsrechten van rechtspersonen in het strafproces
}

\author{
Daan Doorenbos*
}

I Inleiding

\section{I.I Een verwaarloosd aandachtsgebied?}

Al sinds 1976 geldt de rechtspersoon binnen het strafrecht als een volwaardig rechtssubject. Net als natuurlijke personen kunnen rechtspersonen strafbare feiten begaan ter zake waarvan zij kunnen worden vervolgd en bestraft. ${ }^{1}$

Aan de strafrechtelijke aansprakelijkheid van de rechtspersoon zijn in de loop van de tijd talrijke wetenschappelijke publicaties gewijd. Verder heeft de rechter op het terrein van het materiële strafrecht al veel vragen beantwoord. Dat geldt bijvoorbeeld voor de vraag met behulp van welke criteria het daderschap van een rechtspersoon kan worden vastgesteld ${ }^{2}$, alsook voor de vraag onder welke voorwaarden de leidinggevenden binnen de rechtspersoon strafrechtelijk aansprakelijk zullen zijn ${ }^{3}$.

De vraag welke verdedigingsrechten een verdachte rechtspersoon heeft en hoe hij deze op praktische en effectieve wijze kan uitoefenen, heeft van meet af aan relatief weinig aandacht gekregen. In de bestaande handboeken op het terrein van het strafprocesrecht komt de positie van de rechtspersoon niet of nauwelijks ter sprake. In de rechtspraak lijkt het debat over het bestaan en de praktische verwezenlijking van verdedigingsrechten nog niet vaak gevoerd. Wellicht heeft dat op zijn beurt weer te maken met de geringe aandacht voor de rechtspersoon als voorwerp van strafrechtelijk onderzoek in de literatuur ${ }^{4}$, maar vermoedelijk zal het ook samenhangen met de omstandigheid dat veel problemen zich voordoen in de opsporingsfase. De discussies die daar plaatsvinden, worden lang niet altijd voortgezet in de zittingszaal, zo de zaak van de rechtspersoon daar al terechtkomt en niet voortijdig wordt afgedaan met een transactie.

Wat daarvan ook zij, het is bepaald opmerkelijk dat we inmiddels vrij exact weten hoe eenvoudig het daderschap van de rechtspersoon kan worden vastgesteld, terwijl de elementaire vraag hoe die rechtspersoon in de opsporingsfase zijn zwijgrecht

Advocaat bij Stibbe in Amsterdam en hoogleraar Ondernemingsstrafrecht aan de Radboud Universiteit in Nijmegen

I Zie artikel $5 \mathrm{I} \mathrm{Sr}$.

2 Zie HR 2I oktober 2003 (Drijfmest), NJ 2006, 328, m.nt. P.A.M. Mevis.

3 Zie HR I6 december I987 (Slavenburg II), NJ I987, 32I en 322, beide m.nt. 't Hart.

4 De Leidse dissertatie van A.L.J. van Strien, De rechtspersoon in het strafproces, Den Haag I996, vormt in dit opzicht een uitzondering. 
kan effectueren nog steeds niet eenduidig is beantwoord. Alleen al daarom is het gerechtvaardigd te stellen dat de verdedigingsrechten van de verdachte rechtspersoon meer aandacht verdienen.

\section{I.2 Waarom raken rechtspersonen steeds vaker betrokken in strafrechtelijk onderzoek?}

Het aantal in Nederland ingeschreven rechtspersonen groeit nog steeds in hoog tempo en ligt intussen op zo'n anderhalf miljoen. ${ }^{5}$ Dat is een veelvoud van het aantal dat aan de orde was ten tijde van de introductie van de algemene bepalingen omtrent de strafbaarheid van rechtspersonen. ${ }^{6}$ Ook toen werd al gewezen op het feit dat de rechtspersoon kwantitatief een steeds belangrijker plaats was gaan innemen in onze samenleving: een constatering die enkel aan kracht heeft gewonnen. Het aantal in Nederland actieve rechtspersonen zal feitelijk nog hoger liggen dan anderhalf miljoen, omdat uiteraard ook allerlei niet-ingeschreven buitenlandse rechtspersonen zich in onze jurisdictie begeven. ${ }^{7}$ In het maatschappelijk verkeer is de rechtspersoon alom tegenwoordig, bijvoorbeeld als werkgever, als producent, als leverancier, als dienstverlener, als overheid of als sportclub. Elk mens heeft dagelijks van doen met een veelheid van rechtspersonen, die zich aan hem presenteren in de vorm van hun logo's en in de persoon van hun werknemers.

De activiteiten die rechtspersonen ondernemen, zijn vrijwel altijd gereguleerd in wettelijke voorschriften waarvan de overtreding een strafbaar feit oplevert. Alleen al de massa ordeningswetgeving die onder de WED ressorteert, staat garant voor duizenden delictsomschrijvingen. ${ }^{8}$ De commune strafbepalingen bakenen het veld verder af. Waar ook voor rechtspersonen geldt dat waar gehakt wordt spaanders

5 In Asser/Maeijer \& Kroeze 2-I* (Rechtspersonenrecht, De rechtspersoon), Deventer 20I5, worden aantallen gegeven naar de stand van I november 20I4. Op die datum telde het handelsregister 6.282 publiekrechtelijke rechtspersonen (Staat, provincies, gemeenten, waterschappen en overige lichamen) en I.263.6I8 privaatrechtelijke rechtspersonen (I23.726 verenigingen, 7.902 coöperaties, 384 onderlinge waarborgmaatschappijen, 5.889 naamloze vennootschappen, 897.519 besloten vennootschappen en 228.198 stichtingen). Daarnaast stonden 223.163 personenvennootschappen ingeschreven (36.I44 maatschappen, I76.335 vennootschappen onder firma, I0.585 commanditaire vennootschappen en 99 rederijen). Naar huidig recht bezitten personenvennootschappen geen rechtspersoonlijkheid, maar voor de toepassing van het straf- en strafprocesrecht worden zij met de rechtspersoon gelijkgesteld (art. $5 \mathrm{I}$ lid $3 \mathrm{Sr}$ ) en daarom worden zij hier als rechtspersoon meegeteld. Het totaal van deze momentopname komt dan op I.493.063 ingeschreven Nederlandse rechtspersonen, nog afgezien van de vele rechtspersoonlijkheid bezittende (zelfstandige onderdelen van) kerkgenootschappen die ons land rijk is (art. 2:2 lid I BW) en de restcategorie van de doelvermogens (art. $5 \mathrm{I}$ lid $3 \mathrm{Sr}$ ).

6 Zie Kamerstukken II I975/76, I3 655, nr 3, p. 9.

7 Uit de rechtspraak blijkt dat ook buitenlandse rechtspersonen zich met enige regelmaat moeten verantwoorden voor de Nederlandse strafrechter. De vervolging betreft dan bijvoorbeeld een BVBA, $\mathrm{GmbH}$, Inc, Ltd, SA of SARL. Aangenomen wordt dat ook dergelijke juridische entiteiten onder de reikwijdte van het rechtspersoon-begrip van artikel 5I Sr vallen. Zie in dat verband o.a. HR 8 maart I988, NJ I988, 839; HR I3 november 200I, NJ 2002, 2I9; HR 20 december 20II, LJN BQ2472.

8 Zie art. I en Ia WED. Daarin worden ongeveer honderd wetten opgesomd, die praktisch allemaal als grondslag dienen voor verdere, nog omvangrijker uitvoeringswetgeving in de vorm van AMvB's, ministeriële regelingen, et cetera. Als gevolg van deze gelede normstelling kunnen ontelbare uitvoeringsvoorschriften als delictsomschrijving fungeren. Zie daarover o.a. D.R. Doorenbos, Schets van het economisch strafrecht, 8 druk, Deventer 2015, p. 20-25. 
vallen en dat een ongeluk in een klein hoekje zit, is niet verwonderlijk dat menig rechtspersoon in zijn actieve bestaan met het strafrecht in aanraking komt. Dat geldt overigens net zo goed voor commerciële rechtspersonen met klinkende namen en reputaties in het bedrijfsleven ${ }^{9}$, als voor lagere overheden en non-profitorganisaties ${ }^{10}$.

Er hoeft bij de rechtspersoon geen sprake te zijn geweest van boos opzet, kwade trouw of frauduleuze intenties om betrokken te raken in een strafrechtelijk onderzoek. Ook de slordigheid, nalatigheid of vergissingen van een of meer individuele werknemers, een collectieve miscommunicatie of een ongelukkige samenloop van omstandigheden kunnen de rechtspersoon in strafrechtelijk vaarwater doen belanden. ${ }^{\mathrm{II}}$

Daar komt bij dat het gedrag van rechtspersonen in de moderne maatschappij kritisch wordt gevolgd. Er is een trend waarneembaar om rechtspersonen steeds vaker langs strafrechtelijke weg ter verantwoording te roepen, een ontwikkeling die nadrukkelijk mede betrekking heeft op internationaal opererende ondernemingen en hun vermeende misdragingen in andere landen ${ }^{12}$ en tevens op publiekrechtelijke rechtspersonen die hun zorgplichten zouden verzaken ${ }^{13}$. Het vervolgingsbeleid in dezen wordt duidelijk mede beïnvloed door de politiek, de media, internationale samenwerkingsverbanden en belangenorganisaties. ${ }^{14}$

Deze ontwikkelingen raken de rechtspersoon, maar ook zijn leidinggevenden en al diegenen die tot zijn organisatie behoren. Tegen deze achtergrond bezien, zal het

9 Klassieke arresten op het terrein van het ondernemingsstrafrecht zijn die inzake V\&D, de Bijenkorf, Van Gend \& Loos en (de top van) Slavenburg's Bank. In de afgelopen jaren waren ondernemingen als Ahold, Ballast Nedam, KPMG, Rabobank en SBM Offshore voorwerp van strafrechtelijk onderzoek.

Io Klassieke arresten waarin publiekrechtelijke rechtspersonen werden vervolgd, zijn die inzake de gemeenten Tilburg, Voorburg, Boarnsterhim en Etten-Leur. Ook de Rijksuniversiteit Groningen, de Staat der Nederlanden en Euratom zijn al eens strafrechtelijk vervolgd. Waar het gaat om culpoze delicten richt de strafvervolging zich nogal eens op ziekenhuizen en andere zorginstellingen.

II Zo volgt tegenwoordig op bijna elke ramp of calamiteit een strafrechtelijk onderzoek. Vgl. daarover D.R. Doorenbos, 'Schuldige rechtspersonen in de risico-maatschappij, Toerekenen, toerekenen en nog eens toerekenen', in: P.H.P.H.M.C. van Kempen e.a. (red.), Levend strafrecht (Liber amicorum Ybo Buruma), Deventer 20II, p. I43-I53.

I2 Hierbij moet vooral worden gedacht aan de aanpak van buitenlandse corruptie, maar meer in het algemeen ook aan de strafrechtelijke sanctionering van 'maatschappelijk verantwoord ondernemen'. Zie daarover o.a. F.G.H. Kristen, Maatschappelijk verantwoord ondernemen en strafrecht, NJV-preadvies 2010, p. I2I-I89.

I3 De rechtspraak van het EHRM op het vlak van de 'positieve verplichtingen' geeft een aanzet tot strafrechtelijk optreden tegen publiekrechtelijke rechtspersonen. Vgl. o.a. EHRM 30 november 2004 (Öneryildiz), NJ 2005, 2I0, alsmede EHRM 20 maart 2008 (Budayeva), NJ 2009, 229, beide m.nt. E.A. Alkema. Daarnaast zullen die rechtspersonen in Nederland binnenkort in geen enkel opzicht meer 'immuun' zijn voor strafvervolging. Het wetsvoorstel dat strekt tot opheffing van de strafrechtelijke immuniteit van publiekrechtelijke rechtspersonen is reeds door de Tweede Kamer aanvaard en ligt gereed voor openbare behandeling door de Eerste Kamer; zie Kamerstukken I, 2014/15, 30538 , E (Eindverslag d.d. 26 mei 2015).

I4 Belangenorganisaties trachten in toenemende mate privaatrechtelijke en publiekrechtelijke rechtspersonen voor de strafrechter te doen brengen door middel van de beklagprocedure ex artikel I2 Sv. Zie o.a. Hof Arnhem 23 september 2002, NJ 2002, 550 (klacht over het niet vervolgen van de Staat en de gemeente Enschede ter zake van de vuurwerkramp), Hof 's-Gravenhage I2 april 20II, $M$ en R 20II, I57, m.nt. Van Ham (klacht over het niet vervolgen van Trafigura Beheer BV in de Probo Koala-zaak) en Hof 's-Gravenhage I9 mei 2015, NBStraf 2015, II9, m.nt. J.T.C. Leliveld (klacht over het niet vervolgen van de Rabobank ter zake van de Libor-affaire). 
thema 'verdedigingsrechten voor rechtspersonen' al diegenen die werkzaam zijn in de sfeer van rechtspersonen moeten interesseren.

\section{I.3 Beknopt overzicht van het vervolg}

In het eerste deel van dit preadvies zal worden ingegaan op de regeling die het Wetboek van Strafvordering inhoudt voor het geval de verdachte een rechtspersoon is. Die regeling is beperkt tot de vertegenwoordiging ter terechtzitting en voorschriften inzake het uitreiken van gerechtelijke stukken aan rechtspersonen. Vooral de vertegenwoordigingsregeling is hier van groot belang, omdat zij direct van betekenis is voor de wijze waarop de rechtspersoon zijn verdediging zal kunnen voeren en omdat zij ook invloed kan hebben op de fase die aan de terechtzitting voorafgaat. Omdat in de vertegenwoordigingsregeling een centrale rol is weggelegd voor de bestuurders van de rechtspersoon, zal in dit eerste deel van het preadvies vooral ook hun positie in het strafrechtelijk onderzoek worden belicht.

In het tweede deel van het preadvies wordt ingegaan op de positie van de rechtspersoon en zijn werknemers in het voorbereidend onderzoek, de fase waarin bewijsgaring plaatsvindt, dwangmiddelen worden ingezet en verhoren worden afgenomen. Op dat onderdeel bevat het Wetboek van Strafvordering geen bijzondere voorschriften aangaande de rechtspositie van de rechtspersoon en dienen zich lastige vragen aan. In dat kader wordt aandacht besteed aan de mogelijkheid dat de rechtspersoon toestemming verleent tot onderzoeksverrichtingen, aan het bestaan van medewerkingsverplichtingen in het strafrechtelijk onderzoek en aan de (doorwerking van de) belangrijkste verdragsrechten die de rechtspersoon bescherming kunnen bieden tegen grensoverschrijdend overheidsoptreden: de artikelen 6 en 8 EVRM. Daarbij zal de bespreking zich concentreren op de verklaringsvrijheid, het zwijgrecht en het huisrecht van de rechtspersoon.

\section{Vertegenwoordiging van de rechtspersoon in het strafprocesrecht}

\section{I Algemene regels voor vertegenwoordiging}

Omdat de rechtspersoon uiteindelijk een juridische constructie is, kan hij slechts deelnemen aan het maatschappelijk verkeer door middel van zijn vertegenwoordigers. In algemene zin wordt de rechtspersoon vertegenwoordigd door zijn bestuur. ${ }^{15}$ De bevoegdheid tot vertegenwoordiging van de rechtspersoon komt tevens toe aan iedere bestuurder, behoudens eventuele statutaire beperkingen. ${ }^{\mathrm{I}}{ }^{6}$

Het optreden in rechte namens de rechtspersoon wordt gerekend tot de bestuurstaak. ${ }^{17}$ Indien de rechtspersoon wordt betrokken in een juridische procedure en er moet worden beslist over het bepalen van de processtrategie, is het dus aan de bestuurders om daar de lijnen uit te zetten. De keuze van de raadsman, het overleg

I5 Zie o.m. art. 2:I30 lid I BW (voor de NV) en 2:240 lid I BW (voor de BV).

I6 Zie o.m. art. 2:I3o lid 2 BW (voor de NV) en 2:240 lid 2 BW (voor de BV).

I7 Zie Asser/Maeijer/Van Solinge \& Nieuwe Weme 2-II* (Rechtspersonenrecht, De naamloze en besloten vennootschap), Deventer 2009, nr 39I. 
over de aanpak van de zaak, de coördinatie van werkzaamheden en de financiering daarvan: het zijn allemaal zaken waarover door het bestuur van de rechtspersoon zal moeten worden beslist. Het bestuur bepaalt derhalve in vergaande mate hoe de rechtspersoon zich zal opstellen tegenover zijn juridische tegenstander.

Vanuit dit perspectief bezien, zal het bestuur van de rechtspersoon ook een centrale rol (moeten) spelen ingeval die rechtspersoon voorwerp wordt van een strafrechtelijk onderzoek respectievelijk een strafrechtelijke procedure. Het bestuur moet uiteindelijk beslissen over de vraag hoe de verdedigingsrechten van de rechtspersoon worden uitgeoefend en neemt in zoverre een bijzondere positie in.

Zoals hierna zal blijken, sluit de wettelijke regeling over de vertegenwoordiging van de rechtspersoon in het strafproces tot op zekere hoogte aan bij de algemene regels. Tegelijkertijd laat zij nogal wat onzekerheid bestaan over de positie van bestuurders in strafrechtelijke aangelegenheden, omdat de regeling onvoldoende is uitgewerkt en haar reikwijdte beperkt is.

\subsection{Bijzondere regels voor vertegenwoordiging in het strafprocesrecht}

\section{Historisch perspectief}

Ten tijde van de totstandkoming van het Wetboek van Strafrecht werd uitgegaan van het adagium societas delinquere non potest ${ }^{18}$ en bestond dus geen behoefte aan een regeling voor de vertegenwoordiging van de rechtspersoon in strafzaken. In de bijzondere wetgeving werd vervolgens steeds vaker afstand genomen van dat adagium, door de erkenning dat de rechtspersoon wel strafbare feiten kon begaan, maar het bleef lange tijd onmogelijk de rechtspersoon daarvoor te vervolgen. De strafrechtelijke verantwoordelijkheid en aansprakelijkheid werd dan verlegd naar bestuurders en commissarissen respectievelijk naar opdrachtgevers en feitelijke leidinggevenden. ${ }^{19}$ Ook bij zulke regelingen bleef de rechtspersoon als zodanig buiten schot en was een regeling inzake de vertegenwoordiging onnodig.

\section{Economisch Sanctiebesluit 1941}

Deze stand van zaken veranderde gedurende de Tweede Wereldoorlog, toen de bezetter in het Economisch Sanctiebesluit I94I niet alleen bepaalde dat rechtspersonen strafbare feiten konden begaan, maar tevens dat zij daarvoor konden worden vervolgd en bestraft. ${ }^{20}$ Met het uitvaardigen van deze bepalingen - die voortleven in het huidige artikel 5I Sr - was de behoefte aanwezig ook een regeling te treffen voor het geval een rechtspersoon inderdaad zou worden vervolgd. Deze regeling ${ }^{21}$ luidde als volgt:

I8 Zie H.J. Smidt, Geschiedenis van het Wetboek van Strafrecht, deel I, $2^{\mathrm{e}}$ druk, Haarlem I89I, p. 450.

I9 Zie D.R. Doorenbos, 'Bestuurdersaansprakelijkheid in het strafrecht', in: M. Holtzer, A.F.J.A. Leijten en D.J. Oranje (red.), Geschriften vanwege de Vereniging Corporate Litigation 2014-2015, Deventer 20I5, p. 305-32I, met nadere bronvermelding.

20 Zie artikel 6 van het Economisch Sanctiebesluit I94I (Verordeningenblad I94I/I74) zoals gewijzigd en aangevuld bij het Besluit van 3 februari 1943 (Verordeningenblad I943/17).

2I Zie het eerste lid van artikel 6a van het Economisch Sanctiebesluit I94I (Verordeningenblad I94I/174) zoals gewijzigd en aangevuld bij het Besluit van 3 februari 1943 (Verordeningenblad I943/I7). 
'Indien een strafvervolging wordt ingesteld tegen een rechtspersoon, een vennootschap, een vereeniging van personen of een doelvermogen, wordt deze tijdens de vervolging vertegenwoordigd door den bestuurder, indien er meerdere bestuurders zijn door het hoofd van het bestuur of, bij gebreke daarvan, door den door het openbaar ministerie aangewezen bestuurder. De vertegenwoordiger kan bij gemachtigde verschijnen, tenzij het gerecht persoonlijke verschijning gelast.'

De vertegenwoordiging van de rechtspersoon in het strafproces werd aldus toebedacht aan de individuele bestuurder. Deze kon zich op zijn beurt laten vertegenwoordigen door een gemachtigde, met dien verstande dat het gerecht daar in voorkomend geval geen genoegen mee zou hoeven nemen en de bestuurder in kwestie persoonlijk zou kunnen laten verschijnen.

Opmerkelijk is nog de bevoegdheid van het openbaar ministerie om bij een meerhoofdig bestuur zonder (kenbare) voorzitter, de bestuurder te kunnen aanwijzen die de rechtspersoon zal moeten vertegenwoordigen. In voorkomend geval kon de aanklager dus bepalen wie voor de beklaagde het woord zou moeten doen. Vanuit het perspectief van de verdediging is dat niet onbedenkelijk.

De regeling is destijds niet nader toegelicht. Zij oogt als een praktische handleiding waarmee men enerzijds wilde voorkomen dat de rechtspersoon zijn voltallige bestuur zou afvaardigen en anderzijds wilde veiligstellen dat er wel steeds een aanspreekbare vertegenwoordiger zou zijn.

\section{Wet op de Economische Delicten}

Met het einde van de bezetting kwam het Economisch Sanctiebesluit te vervallen. De bepalingen inzake het daderschap en de vervolgbaarheid van de rechtspersoon keerden echter korte tijd later alweer terug in het wetsvoorstel dat zou uitmonden in de Wet op de Economische Delicten (WED). Op het punt van de regeling inzake de vertegenwoordiging werd een identieke bepaling voorgesteld als die uit het Economisch Sanctiebesluit, met als enige toevoeging dat het gerecht voortaan ook een bevel tot medebrenging zou moeten kunnen uitvaardigen jegens de bestuurdervertegenwoordiger van wie het gerecht de persoonlijke verschijning zou wensen. ${ }^{22}$

In de Tweede Kamer werd vervolgens enige discussie gevoerd over de bevoegdheid van het openbaar ministerie om, bij gebreke van een hoofd van het bestuur, een bestuurder aan te wijzen. ${ }^{23}$ Niet alle Kamerleden achtten dat wenselijk. Naar aanleiding van die discussie verklaarde de regering dat het de voorkeur verdiende deze bevoegdheid achterwege te laten: 'De rechtspersoon kan dan zelf beslissen door welke bestuurder zij zich wil laten vertegenwoordigen. De rechter zal dan de bevoegdheid moeten hebben om de persoonlijke verschijning van elk der bestuurders te gelasten. Het ontwerp is in deze zin aangepast.'24

De aldus aangepaste vertegenwoordigingsregeling werd neergelegd in het derde lid van artikel I5 WED en was vanaf I95I van kracht op het terrein van het economisch strafrecht.

22 Zie Kamerstukken II I947/48, 603, $\mathrm{nr}$ 2, het oorspronkelijk voorgestelde derde lid van artikel I5 WED.

23 Zie Kamerstukken II I947/48, 603, nr 4, p. 17. Zie daarover ook A.L. J. van Strien, De rechtspersoon in het strafproces, diss. Leiden, Den Haag I996, p. I28-I29.

Zie Kamerstukken II 1948/49, 603, nr 5, p. I6. 
Een kwart eeuw later achtte de Nederlandse wetgever de tijd rijp voor de introductie van een algemene regeling inzake het daderschap en de vervolgbaarheid van de rechtspersoon. ${ }^{25}$ Bij gelegenheid daarvan is de inhoud van artikel I5 WED gesplitst. Het materiële deel werd ondergebracht in artikel 5I Sr, het formele deel werd opgenomen het Wetboek van Strafvordering.

Artikel 528 Sv luidt nu als volgt:

I. 'Indien een strafvervolging wordt ingesteld tegen een rechtspersoon, doelvermogen of rederij, wordt deze rechtspersoon of dit doelvermogen tijdens de vervolging vertegenwoordigd door de bestuurder of, indien er meer bestuurders zijn, door een van hen en de rederij door de boekhouder of een der leden van de rederij. De vertegenwoordiger kan bij gemachtigde verschijnen.

2. Indien de strafvervolging wordt ingesteld tegen een maatschap of vennootschap zonder rechtspersoonlijkheid, wordt deze tijdens de vervolging vertegenwoordigd door de aansprakelijke vennoot of, indien er meer aansprakelijke vennoten zijn, door een van hen. De vertegenwoordiger kan bij gemachtigde verschijnen.

3. De rechter kan de persoonlijke verschijning van een bepaalde bestuurder of vennoot bevelen; hij kan alsdan zijn medebrenging gelasten.'

Vergelijking met de tekst van haar voorgangers leert dat de oorspronkelijke vertegenwoordigingsregeling in de kern nooit echt is veranderd. Uiterlijk is daarmee sprake van een rustig bezit ${ }^{26}$, maar het betekent niet dat deze summiere regeling geen vragen oproept, zoals hierna zal blijken. Gemakshalve zal ik de nadere bespreking van de regeling beperken tot de rechtspersoon. Mutatis mutandis geldt het gestelde dan tevens voor de overige entiteiten.

\subsection{De positie van de vertegenwoordiger}

De verdedigingsrechten van de verdachte rechtspersoon zullen noodzakelijkerwijs moeten worden uitgeoefend door de vertegenwoordiger(s) van de rechtspersoon. Ter zitting zal de cautie aan de rechtspersoon daarom moeten worden gegeven aan de vertegenwoordiger. ${ }^{27}$ Indien de rechter vragen stelt aan de rechtspersoon, zullen deze worden gericht tot de vertegenwoordiger. En de verklaringen die deze vertegenwoordiger aflegt, hebben rechtens te gelden als de verklaringen van de verdachte rechtspersoon zelf. Kortom: al hetgeen de vertegenwoordiger zegt, doet en

25 Zie de Wet van 23 juni 1976 houdende vaststelling van algemene bepalingen omtrent de strafbaarheid van rechtspersonen, Stb. 1976, 377, in werking getreden op I september 1976.

26 Zie ter illustratie het standaardwerk van G.J.M. Corstens, Het Nederlands strafprocesrecht, 8 e druk, bewerkt door M.J. Borgers, Deventer 20I4, dat inmiddels ruim duizend pagina's beslaat, maar inhoudelijk geen aandacht besteedt aan de regeling van artikel $528 \mathrm{~Sv}$. Er wordt volstaan met de vermelding dat deze regeling bestaat (p. 658). 
nalaat, wordt rechtstreeks toegerekend aan de rechtspersoon, als zijnde de uitingen en gedragingen van die rechtspersoon. De vertegenwoordiger wordt aldus geïdentificeerd met de rechtspersoon. ${ }^{28}$

\subsection{De vertegenwoordiger is geen getuige}

Omdat de vertegenwoordiger moet worden geïdentificeerd met de verdachte rechtspersoon, is het logisch dat hij niet tegelijkertijd een andere hoedanigheid kan hebben. De vertegenwoordiger zal op de zitting in de zaak van de rechtspersoon dus niet als getuige kunnen optreden. Dit werd reeds onderkend in de wetsgeschiedenis $^{29}$ en vindt ook bevestiging in de rechtspraak van de Hoge Raad:

'In het Nederlandse stelsel van strafvordering past niet ter terechtzitting als getuige te horen degene die in dezelfde zaak als vertegenwoordiger van de verdachte optreedt.' ${ }^{\circ \circ}$

Voor de bestuurder die als vertegenwoordiger van de verdachte rechtspersoon ter zitting is verschenen betekent dit dus dat hij niet als getuige kan worden gehoord. Hij staat niet onder ede en hoeft ook geen vragen te beantwoorden indien hij dat niet wenselijk acht.

Hetzelfde zal gelden voor de bestuurder die niet als vertegenwoordiger is verschenen, maar die door de rechter is bevolen ter zitting te verschijnen op de voet van het bepaalde in artikel 528 lid $3 \mathrm{~Sv}$. Ofschoon de wet zwijgt over zijn processuele hoedanigheid, moet worden aangenomen dat hij geen getuige is, maar vertegenwoordiger. ${ }^{3 \mathrm{I}} \mathrm{Hij}$ wordt immers niet als getuige opgeroepen, maar wordt als bestuurder tot verschijnen verplicht en op grondslag van de vertegenwoordigingsregeling gehoord. Ook deze bestuurder kan dus de verdedigingsrechten van de verdachte rechtspersoon uitoefenen. ${ }^{32}$

28 Zie A.L.J. van Strien, De rechtspersoon in het strafproces, diss. Leiden, Den Haag I996, p. I29-I3I, die in dit verband spreekt van 'het stelsel van vereenzelviging'. Idem in Melai c.s., Wetboek van Strafvordering (losbl.), aant. 5.2 bij art. $528 \mathrm{~Sv}$ (suppl. I6I, juni 2007). Tegen het aldus vereenzelvigen van de vertegenwoordiger en de verdachte rechtspersoon in het strafproces bestaan weinig bezwaren, hetgeen uiteraard anders is waar het gaat om de toepassing van het materiële strafrecht. Het is rechtens niet mogelijk de vertegenwoordiger de straf of maatregel van de veroordeelde rechtspersoon te doen ondergaan.

29 Zie Kamerstukken II I975/76, I3 655, nr 3, p. 25.

30 Zie HR 25 juni I99I, NJ I992, 7. Vgl. meer recent nog HR NJ 20I4, 474, m.nt. J.M. Reijntjes, waarin eveneens werd overwogen dat het tegelijkertijd horen van iemand als verdachte in zijn eigen strafzaak èn als getuige in de strafzaak tegen een medeverdachte, niet past in het Nederlandse stelsel van strafvordering, in het bijzonder niet omdat daardoor de aan art. 29 Sv ten grondslag liggende verklaringsvrijheid van de verdachte op ontoelaatbare wijze onder druk kan komen te staan.

3I In dezelfde zin CAG (Meijers) bij HR 26 januari I988, NJ I988, 8I5: 'Het derde lid van art. 528 stelt de bevoegdheid van de rechter vast, de persoonlijke verschijning van een bepaalde bestuurder te bevelen en diens medebrenging te gelasten. Maakt de rechter na de aanvang van het onderzoek ter terechtzitting van die bevoegdheid gebruik, dan zal de rechtspersoon, die reeds door een bestuurder werd vertegenwoordigd (lid I), tijdens de vervolging tegelijkertijd door meer dan een bestuurder zijn vertegenwoordigd.'

32 Zo ook J.A.W. Lensing, Het verhoor van de verdachte in strafzaken, diss. Nijmegen, Arnhem I988, p. I42. 


\subsection{Kan een bestuurder nog getuige zijn in de strafzaak tegen de rechtspersoon?}

In het verlengde van het voorgaande ligt de meer complexe vraag of de rechter nog wel de mogelijkheid heeft om - met voorbijgaan aan artikel 528 lid 3 Sv - een bestuurder die niet als vertegenwoordiger is verschenen, als getuige te doen verschijnen in de strafzaak tegen de rechtspersoon. Uit een oogpunt van waarheidsvinding zou dat wellicht gunstig kunnen zijn, omdat de bestuurder als beëdigde getuige ter zitting de waarheid zal moeten spreken. Het zwijgrecht zou hij als getuige niet meer kunnen uitoefenen en de reikwijdte van het verschoningsrecht van artikel 2I9 $\mathrm{Sv}^{33}$ is uiterlijk beperkt tot bepaalde vragen die het risico van zelfincriminatie inhouden. In voorkomend geval zou de bestuurder dan nog steeds kunnen worden gedwongen belastend te verklaren over de verdachte rechtspersoon.

In de memorie van toelichting bij artikel $528 \mathrm{~Sv}$ staat te lezen dat een bestuurder die de rechtspersoon in de strafzaak niet vertegenwoordigt, op zichzelf wel als getuige zou kunnen worden gehoord in de strafzaak tegen de rechtspersoon. ${ }^{34}$ Dat zou dan overigens wel tot de merkwaardige situatie leiden dat de ene bestuurder (vertegenwoordiger) staande de zitting zijn collega-bestuurder (getuige) zal kunnen ondervragen en zo nodig de verklaring van zijn collega-bestuurder zou moeten betwisten. ${ }^{35}$

Het gerechtshof te Leeuwarden heeft in 1986 echter uitdrukkelijk beslist dat dit niet (meer) kan. De bepaling van artikel 528 lid 3 Sv werd door het hof in de kern beschouwd als een bijzondere regeling die in de weg staat aan de toepassing van de algemene regeling inzake het doen oproepen van getuigen zoals voorzien in artikel 3I5 Sv.

Het ging daar om een strafzaak tegen een rechtspersoon waarbij ter zitting van het hof twee bestuurders waren verschenen: één bestuurder die zich presenteerde als de vertegenwoordiger van de rechtspersoon en één bestuurder die de verdediging had meegebracht om hem ter zitting als getuige te doen horen. Het hof wees het verzoek om getuigenverhoor echter af. Het proces-verbaal van de terechtzitting vermeldde daarover het volgende:

'De voorzitter deelt mede, dat het hof van oordeel is dat Bathoorn als bestuurder van verdachte niet als getuige in verdachtes zaak kan worden gehoord en dat derhalve het door de raadsman gedane verzoek wordt afgewezen. Het bepaalde in art. 528 lid I jo. lid 3 Sv brengt - anders dan uit de m.v.t. op genoemd artikel kan worden afgeleid (Tweede Kamer, 1975-1976, 13655, nr. 3, p. 25) - mede dat een bestuurder, ook al vertegenwoordigt hij de rechtspersoon niet, niet als getuige in de zaak tegen de rechtspersoon kan optreden, omdat het derde lid van voornoemd artikel immers overbodig zou zijn als bedoelde bestuurder wel als getuige zou kunnen optreden, nu reeds op grond van art. 3 I5 $\mathrm{Sv}$ de verschijning van een getuige ter terechtzitting kan worden bevolen, eventueel met een bevel tot medebrenging.'

33 Zie daarover hierna, onderdeel 2.7.

34 Zie Kamerstukken II I975/76, I3 655, nr 3, p. 25.

35 Zie art. 292 lid 3 Sv. 
Het hof besloot de bestuurder vervolgens echter wel als - tweede - vertegenwoordiger van de rechtspersoon te horen. In cassatie werd daarover geklaagd en gesteld dat een rechtspersoon ter terechtzitting slechts één vertegenwoordiger zou mogen hebben. De A-G Meijers concludeerde tot verwerping en de Hoge Raad volgde deze conclusie. Het arrest van het hof bleef daarmee in stand.

De bestuurder lijkt daarmee te zijn uitgeschakeld als potentiële getuige in de strafzaak tegen de rechtspersoon, althans waar het gaat om een optreden als getuige ter zitting. ${ }^{36}$ De bestuurder kan in die fase nog uitsluitend als vertegenwoordiger worden gehoord, waarbij de verklaringsvrijheid is gewaarborgd.

In het verlengde van 's hofs arrest kan vervolgens de vraag worden gesteld of het dan nog wèl mogelijk is de bestuurder in de opsporingsfase als getuige te horen. Zoals hierna nog zal worden besproken ${ }^{37}$, is de regeling van artikel $528 \mathrm{~Sv}$ toegesneden op de vervolgingsfase, maar daaraan gaat de opsporingsfase vooraf. In die eerste fase zal binnen de rechtspersoon nog lang niet altijd zijn beslist welke bestuurder hem tijdens de vervolgingsfase zal gaan vertegenwoordigen. Mag een opsporingsambtenaar daarvan gebruik maken door te stellen dat de bestuurders in strafvorderlijke zin 'dus' nog geen vertegenwoordigers kunnen zijn, zodat ze in dit stadium wel als getuige kunnen worden gehoord? Of doet ook in deze fase niet ter zake wie de rechtspersoon te zijner tijd zal vertegenwoordigen?

Uit de wetsgeschiedenis blijkt in elk geval dat de regering hier nog geen probleem zag. Indien de bestuurder die de rechtspersoon ter zitting vertegenwoordigt in het voorbereidend onderzoek reeds wel als getuige is gehoord, staat het de rechter vrij die eerder als getuige afgelegde verklaring voor het bewijs te gebruiken, ook al zou de bestuurder ter zitting anders hebben verklaard, zo stelde zij destijds..$^{38}$ Daaruit volgt dat het horen van een bestuurder als getuige in het opsporingsonderzoek niet ontoelaatbaar werd geacht, hetgeen door de Hoge Raad lijkt te zijn onderschreven. ${ }^{39}$

Het komt mij voor dat dit standpunt heroverweging verdient. Er is veel voor te zeggen om, net als het hof in zijn hiervoor aangehaalde arrest, afstand te nemen van de wetsgeschiedenis. Gezien de centrale positie van bestuurders binnen de organisatie van de rechtspersoon zou naar mijn oordeel ook in de opsporingsfase als uitgangspunt moeten gelden dat de bestuurders per definitie vertegenwoordigers zijn - wat zij volgens het Burgerlijk Wetboek ook zijn - zodat zij ook als zodanig moeten worden gehoord en dus vooraf de cautie moeten krijgen.

36 Vgl. ook H. de Doelder, 'De onderneming en de strafvordering', Account Dossier I992, nr 7, p. 22-3I, op p. 30.

37 Zie onderdeel 2.I2.

38 Zie Kamerstukken I I975/76, I3 655, nr I40b, p. I, waar de regering overigens spreekt over de bestuurder die ter terechtzitting zijn eerder afgelegde verklaring 'herroept'. Dat laatste is echter strikt genomen niet mogelijk, nu die bestuurder ter zitting dus juist niet als getuige aanwezig is en hij als vertegenwoordiger van de verdachte rechtspersoon uiteraard niet een getuigenverklaring kan herroepen.

Zie HR 9 juni 1992, DD 92.374. 


\subsection{Bezwaren tegen het horen van bestuurders als getuige}

In de literatuur is in het verleden betoogd dat het mogelijk zou moeten zijn bestuurders in de strafzaak tegen hun rechtspersoon te horen als getuigen en hen aldus te dwingen naar waarheid te verklaren, ook en vooral als dat bewijs tegen de rechtspersoon kan opleveren..$^{4}$ Vanuit het perspectief van de verdediging van de rechtspersoon kan dit betoog niet worden gevolgd. De wens om bestuurders te kunnen dwingen belastend te verklaren in de strafzaak tegen hun rechtspersoon, staat haaks op de verklaringsvrijheid waar de rechtspersoon als verdachte aanspraak op heeft.

Het bestuur is niet alleen het vertegenwoordigend orgaan van de rechtspersoon, maar kan ook worden gezien als het centrale sturingscentrum binnen de rechtspersoon-organisatie. ${ }^{4 \mathrm{I}}$ Wanneer die rechtspersoon-organisatie zelf wordt aangemerkt als een volwaardig rechtssubject, met de diverse verdedigingsrechten die aan zodanig rechtssubject in zijn hoedanigheid van een verdachte toekomen, zou het toch vreemd zijn als de leden van het vertegenwoordigend orgaan en centraal sturingscentrum gedwongen zouden kunnen worden naar waarheid te verklaren over mogelijke strafbare gedragingen en berispelijke wetenschap van de rechtspersoon-organisatie. Het bestuur en de individuele bestuurders zijn zodanig nauw verbonden met de verdachte rechtspersoon dat het gekunsteld is hen als een gewone getuige te bejegenen..$^{2}$

Waar in de literatuur wordt betoogd dat de verdachte rechtspersoon geen bestuurders zou mogen 'uitschakelen' als getuigen door ze als vertegenwoordiger aan te wijzen, zou ik willen betogen dat de strafrechtelijke autoriteiten de bestuurders van een verdachte rechtspersoon niet tegen elkaar en tegen die rechtspersoon mag 'uitspelen' door ze te dwingen tot een mogelijk belastende verklaring.

\subsection{Verschoningsrecht voor bestuurders?}

Het hiervóór in onderdeel 2.5 besproken arrest van het gerechtshof Leeuwarden laat enige ruimte voor debat, nu de Hoge Raad niet expliciet heeft ingestemd met de gegeven uitleg. Indien en voor zover nog wèl mogelijk zou worden geacht een bestuurder als getuige te doen horen in de strafzaak tegen de rechtspersoon, rijst de vraag of de bestuurder zich in voorkomend geval dan zou kunnen verschonen van het beantwoorden van vragen. In de wetsgeschiedenis werd in dit verband gewezen op het verschoningsrecht van artikel $2 \mathrm{Ig} \mathrm{Sv} .{ }^{43}$

40 In deze zin o.a. R.A. Torringa, Strafbaarheid van rechtspersonen, diss. Groningen, Arnhem I984, p. I34-I35; A.L.J. van Strien, De rechtspersoon in het strafproces, diss. Leiden, Den Haag I996, p. I34 en 138 .

4I Zie ook J.B. Huizink, Rechtspersoon, vennootschap en onderneming, $3^{\mathrm{e}}$ druk, Deventer 20I3, p. I53, waar hij opmerkt dat 'algemeen aangenomen [wordt] dat het bestuur fungeert als het centrale punt in de organisatie ter zake van de beleidsvoorbereiding, -vaststelling en -uitvoering.'

42 Vgl. in dat verband nog EHRM 6 april 2000 (Comingersoll SA), NJ 2000, 6I2, waarin het Hof de rechtspersoon een schadevergoeding toekende vanwege de schending van de redelijke termijn als bedoeld in artikel 6 lid I EVRM (non-pecuniary damage). In een dergelijk geval delen de bestuurders van de rechtspersoon in het ongemak en de onzekerheid (par. 36) en moet bij de compensatie ook rekening worden gehouden met 'disruption in the management of the company' en 'the anxiety and inconvenience caused to the members of the management team' (par. 35).

Zie Kamerstukken II I947/48, 603, nr 4, p. I7 en Kamerstukken II I948/49, 603, nr 5, p. I6. 
Dat verschoningsrecht is primair van toepassing op de getuige die, door een bepaalde vraag te beantwoorden, zichzelf zou blootstellen aan het gevaar van een strafrechtelijke veroordeling. Denk aan de bestuurder die als getuige zou worden gevraagd naar zijn feitelijke betrokkenheid bij en/of wetenschap van de vermeende strafbare feiten van de rechtspersoon. Een eerlijk antwoord zou hem wel eens verdacht kunnen maken, in welk geval hij zich mag verschonen van beantwoording. Vandaar dat dit verschoningsrecht wel wordt aangeduid als het 'nemo tenetur-verschoningsrecht'. Geheel toereikend is die aanduiding niet, omdat het hier bedoelde verschoningsrecht tevens van toepassing is ingeval het bedoelde gevaar zich zou richten op een nauwe bloed- of aanverwant of op een huidige of vroegere echtgenoot of geregistreerd partner. In de hier besproken context is de aanduiding echter wel adequaat.

In artikel 219 Sv staat te lezen dat de getuige zich kan verschonen van het beantwoorden 'eener hem gestelde vraag'. De reikwijdte lijkt daardoor beperkt en doorgaans wordt dan ook gesteld dat het beroep op dit verschoningsrecht per vraag moet worden beoordeeld. ${ }^{44}$ De Hoge Raad heeft echter aanvaard dat onder omstandigheden dit recht tot verschoning in het algemeen kan worden verleend 'voor alle nog te stellen vragen betrekking hebbende op de feiten waarbij de getuige is betrokken' in de zin van artikel 219 Sv. ${ }^{45}$ Dat impliceert dat in voorkomend geval een algeheel verschoningsrecht kan worden aanvaard en dat de getuige in kwestie daar reeds een beroep op kan doen - en de rechter dat ook kan honoreren - nog voordat hem enige bepaalde vraag is gesteld. ${ }^{46}$

Van belang is nog op te merken dat opsporingsambtenaren en rechters volgens de wet niet verplicht zijn om personen die door hen als getuige worden gehoord uitdrukkelijk te wijzen op hun mogelijk verschoningsrecht. Naast de cautie voor de verdachte ${ }^{47}$ kent het wetboek geen cautie voor de getuige die zichzelf ongewild zou kunnen belasten ${ }^{4}$. De Hoge Raad heeft een dergelijke verplichting niet op eigen kracht willen introduceren. 49

Voor bestuurders die goed op de hoogte zijn van hun rechten en verplichtingen, zal het verschoningsrecht van artikel 2I9 Sv tot op zekere hoogte soelaas kunnen bieden. Dat neemt niet weg dat hun positie duidelijk beter zou zijn gewaarborgd met een zwijgrecht. Een verschoningsrecht geeft in de praktijk vrijwel altijd aanleiding tot discussies over de reikwijdte in het concrete geval en in relatie tot de

Zie o.a. P.P.J. van der Meij in T\&C Strafuordering, $\mathrm{II}^{\mathrm{e}}$ druk, Deventer 20I5, aant. bij art. 2I9 Sv onder het kopje Reikwijdte: 'Anders dan bij de art. 217 en 218 is het verschoningsrecht beperkt tot het beantwoorden van bepaalde vragen. Het lijkt uitgesloten dat een verschoningsrecht op grond van art. 2Ig kan worden ingeroepen voor het gehele getuigenverhoor.'

45 Zie HR i6 januari I990, NJ I990, 4I8

46 Zie HR I5 juni I993, NJ I994, 37.

47 Zie art. 29 lid 2 Sv: 'Voor het verhoor wordt de verdachte medegedeeld dat hij niet verplicht is tot antwoorden.'

48 Een andere keuze zou zeer wel denkbaar zijn. Zie daarover ook B.F. Keulen en G. Knigge, Strafprocesrecht, $\mathrm{I} 2^{\mathrm{e}}$ druk, Deventer 2010, p. 203-204.

49 Zie o.a. HR 30 augustus 2005, NJ 2005, 543. In zijn conclusie voor dit arrest toonde de AG Wortel zich wel een voorstander voor een dergelijke cautieverplichting. Zie ook Hof Leeuwarden ro juli 20I2, NJFS 20I2, 217 (ECLI:NL:GHLEE:20I2:BY0577), dat op grond van beginselen van een behoorlijke procesorde en het EVRM tot een ander oordeel kwam dan de Hoge Raad in voornoemd arrest. 
specifieke vraag en daarbij is op voorhand nooit zeker of de verhorende rechter het beroep wel zal honoreren..$^{\circ}$

Hier komt nog bij dat niet elke bestuurder dit verschoningsrecht zal kunnen inroepen. De bestuurder die niet betrokken is geweest bij de mogelijk strafbare gedragingen en daar ook geen berispelijke wetenschap van had, heeft persoonlijk niets te vrezen en kan zich dus niet verschonen. Met de mogelijkheid dat deze getuigende bestuurder door zijn antwoorden de rechtspersoon en/of zijn collega-bestuurders zou blootstellen aan het gevaar van een strafrechtelijke veroordeling, houdt artikel 2I9 Sv verder geen rekening: het 'nemo tenetur-verschoningsrecht' beperkt zich tot de getuige zelf en zijn bloed- en aanverwanten. In een getuigenverhoor zou de bestuurder dus onder ede wel degelijk gedwongen kunnen worden de verdachte rechtspersoon en zijn medebestuurders te belasten, ofschoon hij zelf tot die rechtspersoon en medebestuurders in een zeer nauwe betrekking staat en hij ook uitsluitend vanwege die betrekking over de relevante kennis beschikt.

In civilibus wordt mogelijk geacht dat een getuige in een zo nauwe betrekking kan staan een procespartij dat de getuige als het ware met die procespartij kan worden 'vereenzelvigd' waar het gaat om het kunnen inroepen van het 'nemo teneturverschoningrecht'. ${ }^{5 \mathrm{I}}$ Dat kan niet alleen indien de getuige een voldoende nauwe familierechtelijke relatie heeft tot de procespartij in kwestie ${ }^{52}$, maar ook indien de getuige een centrale positie heeft binnen de rechtspersoon die als procespartij optreedt. Zo zullen de bestuurders van een rechtspersoon die partij is in een civielrechtelijke procedure in rechte niet kunnen worden gedwongen tot het afleggen van een getuigenverklaring die hun rechtspersoon zou blootstellen aan het gevaar van een strafrechtelijke veroordeling, omdat zij als de wettelijke vertegenwoordigers van die rechtspersoon met hem mogen worden vereenzelvigd. 53

Aldus biedt het civiele procesrecht tot op zekere hoogte een oplossing voor het potentiële probleem dat bestuurders enerzijds geacht worden de belangen van de rechtspersoon in het proces te behartigen en in dat kader de processtrategie mee te bepalen, terwijl zij anderzijds gedwongen zouden kunnen worden te getuigen tegen hun rechtspersoon.

Het is voorstelbaar dat ook de strafrechter een vereenzelvigingsleer ontwikkelt volgens welke in elk geval de wettelijk vertegenwoordigers van de rechtspersoon - i.e. alle bestuurders - zich zouden kunnen verschonen indien wordt getracht hen

50 Nog daargelaten dat een beroep op het 'nemo tenetur-verschoningsrecht' een zelfincriminerend effect heeft: de getuige die (nog) geen verdachte is, suggereert daarmee dat hij nauwer betrokken is dan mogelijk werd gedacht. Deze paradox leidt ertoe dat getuigen niet snel een beroep op dit verschoningsrecht zullen willen doen. Een beroep op het zwijgrecht is minder belastend.

5 I Zie F.J. Fernhout, Het verschoningsrecht van getuigen in civiele zaken, diss. Maastricht, Deventer 2004, p. II5-II6. Het 'nemo-tenetur-verschoningsrecht' in civilibus is vervat in artikel $\mathrm{I}_{5}$ lid $3 \mathrm{Rv}$.

52 Vgl. bijvoorbeeld Hof Amsterdam 9 februari 2006, ECLI:NL:GHAMS:2006:AXoo95, waarin een verschoningsrecht werd aanvaard voor de echtgenote van de statutair directeur (tevens indirect enig aandeelhouder) van de rechtspersoon die optrad als procespartij.

53 Vgl. in dit verband Asser Procesrecht / Asser 3 (Bewijs), Deventer 2013, nr I64, waar wordt opgemerkt dat de bestuurders van een rechtspersoon die procespartij is, met deze partij kunnen worden vereenzelvigd, ook al zijn zij zelf geen procespartij. De bestuurders hebben in hun hoedanigheid dezelfde procesbelangen als de procederende rechtspersoon. 
te horen als getuige in de strafzaak tegen hun rechtspersoon. ${ }^{54}$ Als alternatief zie ik een wettelijke bepaling waarin expliciet wordt opgenomen dat de wettelijke vertegenwoordigers van een verdachte rechtspersoon zich kunnen verschonen van het geven van getuigenis in de strafzaak tegen die rechtspersoon. Een dergelijke bepaling zou veel duidelijkheid scheppen omtrent de positie van bestuurders in een strafrechtelijk onderzoek en zou de rechtszekerheid bevorderen. ${ }^{55}$

\subsection{Keuzevrijheid, ook voor meer dan één vertegenwoordiger}

In de wetsgeschiedenis is tot uitdrukking gebracht dat de rechtspersoon zelf kan beslissen door welke bestuurder hij zich wil laten vertegenwoordigen. Weliswaar kan de rechter ook de andere bestuurders ter zitting doen verschijnen, maar die bevoegdheid doet niet af aan het uitgangspunt dat de keuzevrijheid voor de vertegenwoordiger in eerste instantie bij de rechtspersoon ligt. ${ }^{6}$

Zoals reeds aan de orde kwam, heeft de Hoge Raad in I988 aanvaard dat een rechtspersoon de vrijheid heeft om zich desgewenst door meer dan één bestuurder te laten vertegenwoordigen. ${ }^{57}$ Dit arrest sluit goed aan op de wetsgeschiedenis waarin de keuzevrijheid van de rechtspersoon tot uitgangspunt werd genomen..$^{5}$ Daarnaast is deze uitleg in lijn met de civielrechtelijke hoofdregel dat de rechtspersoon primair wordt vertegenwoordigd door het bestuur, i.e. alle bestuurders.

Vanuit de algemene vertegenwoordigingsregeling van het Burgerlijk Wetboek zal het niet relevant zijn wie van de bestuurders in rechte voor de rechtspersoon optreedt en is dus ieder van de bestuurders kandidaat voor de rol van vertegenwoordiger. In de regeling van artikel $528 \mathrm{~Sv}$ ligt besloten dat ingeval sprake is van een meerhoofdig bestuur, de rechtspersoon kan volstaan met de afvaardiging van slechts één van hen. Deze regel lijkt mij duidelijk een praktische achtergrond te hebben: één bestuurder is voldoende, maar meer bestuurders mag natuurlijk ook, al leidt dat mogelijk tot een iets minder efficiënte behandeling ter zitting.

De wetsgeschiedenis biedt geen enkele grond om aan te nemen dat de wetgever uit was op een beperking van het aantal vertegenwoordigers tot één, met als argument dat de overige bestuurder(s) dan als getuige(n) beschikbaar zouden blijven. ${ }^{59}$ Het aanbrengen van een dergelijke tweedeling binnen het bestuur - de

54 Het lijkt mij niet dat dit de rechtsvormende taak van de Hoge Raad te boven zou gaan. Vgl. in dit verband bijvoorbeeld HR 23 april 1996 (Pikmeer I), NJ I996, 513, m.nt. A.C. 't Hart, waarin een afgeleide immuniteit werd aanvaard voor leidinggevenden van publiekrechtelijke rechtspersonen, op grond van de nauwe verbondenheid tussen de leidinggevende en de rechtspersoon.

55 Ter vergelijking kan nog worden gewezen op het feit dat in mededingingsrechtelijke onderzoeken van de Europese Commissie, de uitoefening van het zwijgrecht door de rechtspersoon uitdrukkelijk ter beslissing staat van 'de krachtens de wet of de statuten tot vertegenwoordiging bevoegde personen'. Vgl. art. I8 lid 4 van Verordening $1 / 2003$ in combinatie met de erkenning van het zwijgrecht in de Orkem-zaak (NJ I99I, 687) e.v., zoals ook opgemerkt in r.o. 5.2 van de uitspraak van het College van Beroep voor het bedrijfsleven van 2I december 2012 over het zwijgrecht van exwerknemers, JOR 2013/48, m.nt. S.M.C. Nuyten.

56 Zie ook A.L.J. van Strien, De rechtspersoon in het strafproces, diss. Leiden, Den Haag I996, p. I28-I29, die spreekt van 'het stelsel van de keuzevrijheid'.

57 Zie HR 26 januari I988, NJ I988, 8I5.

58 Zie hiervóór, onderdeel 2.2.

59 Vgl. ook A.N. Kesteloo, De rechtspersoon in het strafrecht, Deventer 2013, p. I22. 
vertegenwoordiger die mag zwijgen versus de overige bestuurders die moeten spreken - strookt niet met het gegeven dat wettelijk bezien willekeurig is wie van de bestuurders de rechtspersoon vertegenwoordigt en dus evenmin met de daarop aansluitende keuzevrijheid voor de rechtspersoon.

In haar dissertatie heeft Van Strien als bezwaar geopperd dat bij een meervoud aan vertegenwoordigers problemen zouden kunnen ontstaan bij de bewijslevering. Haar bezwaar houdt verband met het voorschrift van artikel 34I lid 4 Sv, inhoudende dat het bewijs dat de verdachte het ten laste gelegde feit heeft begaan, door de rechter niet uitsluitend kan worden aangenomen op de opgaven van de verdachte. Omdat de verklaringen van de vertegenwoordigers uiteindelijk allemaal zullen hebben te gelden als de opgaven van de verdachte rechtspersoon, zou de rechter wel eens kunnen worden geconfronteerd met een bewijstekort, aldus Van Strien. ${ }^{60}$

Dit bezwaar lijkt mij nogal theoretisch. Het is namelijk praktisch ondenkbaar dat in een strafzaak tegen een rechtspersoon geen ander bewijsmateriaal voorhanden is dan verklaringen van vertegenwoordigers van de rechtspersoon. Het dossier zal altijd ook processen-verbaal van ambtsedige waarnemingen van verbalisanten en andere schriftelijke bescheiden bevatten. En daarmee zal het bezwaar realiter reeds van de baan zijn, want de bewijsminimumregel van artikel 34I lid 4 Sv wordt in de rechtspraak beperkt uitgelegd. ${ }^{6 r}$ Het vereiste aanvullend bewijs hoeft geenszins betrekking te hebben op de volle breedte van de tenlastelegging en zal derhalve al snel voldoende steun bieden.

\subsection{Vrees voor het 'uitschakelen' van getuigen}

Het gegeven dat de vertegenwoordiger van de rechtspersoon niet tegelijkertijd als getuige kan optreden, leidde tijdens de parlementaire behandeling van artikel $528 \mathrm{~Sv}$ tot enige discussie. Vanuit de Eerste Kamer werd de vrees geuit 'dat het bestuur diegene van de bestuursleden tot vertegenwoordiger zal benoemen, van wiens getuigenis eventueel de grootste schade wordt geducht'. Voorts werd geconstateerd dat ingeval er slechts één bestuurder is, deze zelfs steeds als getuige zou zijn uitgesloten. ${ }^{62}$

In reactie daarop wees de regering allereerst op het feit dat de getuigenverklaring slechts één van de wettige bewijsmiddelen is. Daarnaast werd gesteld dat de verklaring die een bestuurder mogelijk reeds in het voorbereidend onderzoek zou hebben afgelegd wel degelijk aan het bewijs zou kunnen meewerken, ook indien die bestuurder zijn eerder als getuige afgelegde verklaring ter zitting zou herroepen. En juist ingeval de bestuurder een belangrijke getuige is of de enige bestuurder van de rechtspersoon, is waarschijnlijk dat hij reeds in de voorfase zal zijn gehoord, aldus de regering. Tot slot werd opgemerkt dat zich in de praktijk voor zover bekend op dit punt nimmer specifieke problemen hadden voorgedaan. ${ }^{63}$

6 Zie A.L.J. van Strien, De rechtspersoon in het strafproces, diss. Leiden, Den Haag I996, p. I38.

6I Zie nader G.J.M. Corstens, Het Nederlands strafprocesrecht, $8^{e}$ druk, bewerkt door M.J. Borgers, Deventer 20I4, p. 773, waar wordt gesproken over een 'minimalistische invulling' van de bewijsminimumregel van art. 34I lid 4 Sv.

62 Zie Kamerstukken I I975/76, I3 655, nr I40a.

63 Zie Kamerstukken I I975/76, I3 655, nr I4ob. 
Ofschoon dit laatste werd gesteld in 1976 , geloof ik niet dat zulke problemen zich intussen wèl hebben voorgedaan, ook niet nadat de Hoge Raad in I988 aanvaardde $^{64}$ dat een rechtspersoon de vrijheid heeft om desgewenst meer dan één bestuurder als vertegenwoordiger aan te wijzen.

Door Van Strien is het arrest echter bestreden. Zij noemt in haar dissertatie nog steeds als bezwaar dat de rechtspersoon desgewenst belangrijke getuigen kan 'uitschakelen' en wil daarom dat slechts één persoon tegelijkertijd als vertegenwoordiger van de rechtspersoon kan optreden. Haar kritiek wordt ingegeven door de vrees dat door het zojuist genoemde arrest 'de bewijsvergaring in aanzienlijke mate kan worden bemoeilijkt'. De rechtspersoon zou nu namelijk 'alle bestuurders die wellicht als getuige ertoe gedwongen hadden kunnen worden voor de rechtspersoon belastende verklaringen af te leggen, ter terechtzitting als procesvertegenwoordiger laten optreden'. ${ }^{65}$

Als gezegd, is dergelijke kritiek reeds geuit ten tijde van de totstandkoming van artikel $528 \mathrm{~Sv}$ en toen dus gemotiveerd weerlegd door de regering. ${ }^{66}$ Daarbij is uitdrukkelijk onder ogen gezien dat bij rechtspersonen met slechts één bestuurder, deze ter zitting niet tegelijkertijd als getuige zal kunnen optreden. Die situatie verschilt niet wezenlijk met de situatie dat bij een meerhoofdig bestuur de belangrijkste of zelfs alle bestuurders als vertegenwoordigers optreden, die daar dan niet meer als getuige kunnen worden gehoord.

Los daarvan levert de wens om bestuurders te dwingen tot het afleggen van belastende verklaringen in de strafzaak van hun rechtspersoon geen goede grond op voor wijziging van de wettelijke regeling of de bestaande rechtspraak. De bezwaren tegen het 'uit elkaar spelen' van bestuurders onderling en bestuurders tegenover hun rechtspersoon, werden hiervóór reeds toegelicht. ${ }^{67}$

\section{Io De betekenis van artikel 528 lid $3 \mathrm{~Sv}$}

Het derde lid van artikel $528 \mathrm{~Sv}$ betreft de rechterlijke bevoegdheid om de persoonlijke verschijning te bevelen van 'een bepaalde bestuurder' die niet ter zitting is verschenen. Terwijl deze bevoegdheid oorspronkelijk - in het Economisch Sanctiebesluit I94I - nog uitsluitend was voorzien voor de bestuurder die een gemachtigde naar de zitting had gestuurd, is zij bij gelegenheid van de totstandkoming van de WED uitgebreid tot elke bestuurder. Dat betekent dat ook de bestuurder die door de rechtspersoon niet is aangewezen om als vertegenwoordiger op te treden, door de rechter naar de zitting kan worden gedirigeerd.

De regering gaf destijds geen nadere toelichting op de uitbreiding van de rechterlijke bevoegdheid, maar men mag aannemen dat die uitbreiding was ingegeven door een wens vanuit de Tweede Kamer. In het voorlopig verslag betreffende het wetsvoorstel voor de WED was namelijk opgemerkt dat de rechter de bevoegdheid zou moeten hebben om de persoonlijke verschijning van elk der bestuurders te

64 Zie HR 26 januari I988, NJ I988, 8I5.

65 Zie A.L.J. van Strien, De rechtspersoon in het strafproces, diss. Leiden, Den Haag I996, p. I34.

66 In haar dissertatie gaat Van Strien niet in op deze weerlegging.

67 Zie onderdeel 2.6. 
gelasten respectievelijk dat het mogelijk is dat de rechtbank ook andere bestuurders dan de aangewezen vertegenwoordiger persoonlijk wil ondervragen. ${ }^{68}$

Het is niet erg helder wat de Kamerleden in kwestie hier precies voor ogen stond. Wilden zij de rechter in staat stellen de beslissing van de rechtspersoon inzake de vertegenwoordiger desgewenst te 'overrulen' of wilden zij de rechter in staat stellen de bestuurders van de rechtspersoon desgewenst als quasi-getuigen te doen horen?

Indien artikel 528 lid $3 \mathrm{~Sv}$ zo wordt uitgelegd dat de rechter te allen tijde een andere bestuurder als vertegenwoordiger kan doen verschijnen dan de bestuurder die de rechtspersoon heeft aangewezen of afgevaardigd, dan is dat een uitleg die wezenlijk afbreuk doet aan de zelfstandige beslissingsvrijheid van de verdachte rechtspersoon. De rechter zou in staat zijn de processtrategie van de verdachte rechtspersoon te doorkruisen, door de vertegenwoordiger waarvan de verdachte zelf meent dat die zijn belangen het beste kan behartigen de facto terzijde te schuiven en te doen vervangen door een vertegenwoordiger die daar in de ogen van de verdachte niet of minder geschikt voor is. ${ }^{69}$ Dat zou regelrecht in strijd zijn met het eerder voorgestane uitgangspunt dat de verdachte rechtspersoon zelf moet kunnen beslissen door wie hij zich zal laten vertegenwoordigen.

Mede gezien het feit dat de wetsgeschiedenis in dezen geen enkele nadere toelichting verschaft, acht ik het niet erg aannemelijk dat de wetgever destijds voor ogen heeft gestaan dat de rechter de vertegenwoordiger van de rechtspersoon desgewenst kan laten vervangen door een (of meer) ander(en). Veeleer acht ik aannemelijk dat de Kamerleden in kwestie hebben gedacht aan de mogelijkheid dat bestuurders potentieel interessante verklaringen zouden kunnen afleggen. De nadruk op de mogelijke wens tot 'persoonlijke ondervraging' duidt daarop. Dat brengt ons bij de tweede uitleg, volgens welke de rechterlijke bevoegdheid de (andere) bestuurders te doen verschijnen veeleer verband houdt met waarheidsvinding of bewijsgaring.

In hetzelfde voorlopig verslag waarin de wens werd geuit dat de rechter elk der bestuurders persoonlijk zou willen ondervragen, is ook gesproken over de mogelijkheid bestuurders te horen als potentiële getuigen in de strafzaak tegen de rechtspersoon. Daarbij werd reeds aangetekend dat die bestuurders zich dan in voorkomend geval op het verschoningsrecht ex artikel 219 Sv zouden kunnen beroepen. ${ }^{70}$ De regering onderschreef dat: het horen van de bestuurders in een strafzaak tegen 'hun' rechtspersoon zou volgens haar niet door enige wettelijke bepaling worden verhinderd. ${ }^{71}$ In het verlengde daarvan heeft zij dan mogelijk de voorziening opgenomen die nu in het derde lid van artikel $528 \mathrm{~Sv}$ is neergelegd.

Indien deze tweede lezing juist is, zou op het eerste gezicht gesteld kunnen worden dat de getroffen voorziening niet nodig was, nu de algemene regels inzake het

68 Zie Kamerstukken II I947/48, 603, nr 4, p. I7.

69 De door de rechtspersoon aangewezen vertegenwoordiger zal zijn procesrechtelijke status niet verliezen indien de rechter een andere bestuurder laat verschijnen, maar zijn rol in de communicatie ter zitting zou wel kunnen worden gemarginaliseerd. De vertegenwoordigers kunnen echter ook vasthouden aan hun vooraf bepaalde rolverdeling en dan zal de rechter niet veel verder komen (zie ook hierna, onderdeel 2.II).

70 Zie Kamerstukken II I947/48, 603, nr 4, p. 17.

7 I Zie Kamerstukken II I948/49, 603, nr 5, p. I6. 
oproepen en zo nodig doen medebrengen van getuigen immers reeds toereikend waren. ${ }^{72}$ Gegeven echter dat deze bijzondere voorziening desondanks wel is getroffen, is evenzeer verdedigbaar dat bestuurders sedertdien in het geheel niet meer als getuige ter zitting kunnen optreden in de zaak tegen de rechtspersoon. Zoals we reeds zagen, is dat de uitleg van het gerechtshof te Leeuwarden geweest ${ }^{73}$ en is dat arrest in cassatie in stand gebleven. De bestuurder van een verdachte rechtspersoon kan dan nog slechts als vertegenwoordiger in die zaak ter zitting verschijnen.

\section{II Artikel 528 lid $_{3}$ Sv in het licht van de verdedigingsvrijheid}

Het is mogelijk dat tijdens de behandeling ter terechtzitting blijkt dat de vertegenwoordiger van de rechtspersoon weinig of niets over de zaak kan of wil verklaren. Misschien heeft de rechtspersoon wel expres een vertegenwoordiger naar de zitting gezonden die met betrekking tot het ten laste gelegde feit van niets weet. ${ }^{74}$ Dat kan dan voor openbaar ministerie en rechter ergerlijk frustrerend zijn, omdat het de waarheidsvinding niet verder helpt. Maar legitimeert een dergelijke situatie een rechterlijk bevel om een andere bestuurder te doen verschijnen waarvan wordt verwacht dat hij een meer behulpzame bron van informatie zal zijn dan de bestuurder die de rechtspersoon heeft aangewezen?

In de literatuur wordt dit wel aangenomen.75 Vanuit het perspectief van de verdedigingsvrijheid is een dergelijke toepassing van artikel 528 lid 3 Sv echter niet onbedenkelijk.

Indien een rechtspersoon in het kader van strafrechtelijk overheidsoptreden als verdachte wordt aangemerkt, is het de taak van het bestuur van de rechtspersoon om ervoor te zorgen dat de belangen van de verdachte rechtspersoon binnen het strafrechtelijk onderzoek adequaat worden behartigd. De keuze van de procesvertegenwoordiger(s) is daarbij van groot gewicht, omdat die onderdeel vormt van de inrichting van de verdediging van de rechtspersoon. Het komt mij voor dat het bestuur in die keuze volledig vrij moet zijn. De overheid en ook de rechter behoort zich niet in te laten met de vraag hoe de rechtspersoon zich als verdachte zou moeten opstellen en door wie de rechtspersoon zich wenst te laten vertegenwoordigen. Dat zou strijdig zijn met het uitgangspunt dat een verdachte een autonome procespartij is die zijn eigen keuzes moet kunnen maken. ${ }^{76}$

Het is zeer wel mogelijk dat een opsporingsambtenaar, een officier van justitie of een rechter de processtrategie van de verdachte rechtspersoon in voorkomend geval onwenselijk, ongelukkig of onverstandig vindt. Het is zeer wel mogelijk dat een vertegenwoordiger van de verdachte rechtspersoon zich in de ogen van justitie weinig constructief of zelfs zeer onwillig opstelt. Dat geeft de strafvorderlijke au-

\footnotetext{
72 Vgl. in deze zin F. Hollander, Wet op de economische delicten, Arnhem I952, p. Iog.

73 Hof Leeuwarden 2 juli I986, te kennen uit HR 26 januari I988, NJ I988, 8I5.

74 Zie daarover R.A. Torringa, Strafbaarheid van rechtspersonen, diss. Groningen, Arnhem I984, p. I4I.

75 Zie C.P.M. Cleiren in T\&C Strafuordering, $\mathrm{II}^{\mathrm{e}}$ druk, Deventer 20I5, aant. 8 bij art. 528 Sv. In dezelfde zin reeds R.A. Torringa, Strafbaarheid van rechtspersonen, diss. Groningen, Arnhem I984, p. I4I.

76 Zie in dat verband ook het kernprofiel van de verdachte zoals beschreven in M.S. Groenhuijsen en G. Knigge (red.), Het onderzoek ter zitting, Eerste interimrapport onderzoeksproject Strafvordering 2001, Deventer 200I, p. 33-34.
} 
toriteiten echter niet het recht de procesrechtelijke keuzes van de verdachte rechtspersoon te 'overrulen' en zich te bemoeien met de vraag door wie de rechtspersoon zich in het strafrechtelijk onderzoek en in de strafrechtelijke procedure zou moeten laten vertegenwoordigen. De beantwoording van die vraag raakt de kern van de verdediging en moet daarom principieel aan de verdachte zelf worden overgelaten. ${ }^{77}$

Ter vergelijking kan nog worden gewezen op het feit dat (ook) een verdachte natuurlijk persoon volkomen vrij is in de keuze van zijn procesvertegenwoordiger. Dat geldt zowel voor de keuze van zijn (al of niet gemachtigd) raadsman als voor de keuze van zijn vertegenwoordiger in de gevallen waarin de wet dat toelaat ${ }^{7}$. De rechter kan die keuze niet doorkruisen ingeval hij van oordeel is dat de procesvertegenwoordiger te weinig kennis heeft van de zaak of zich te weinig constructief opstelt. Dat is terecht, want het is aan de verdachte om te bepalen hoe en door wie hij zich wil laten vertegenwoordigen. De keerzijde is, dat de rechter hem daarop mag afrekenen, maar de rechter zal de keuze wel moeten respecteren.

Tegen deze achtergrond valt niet in te zien waarom de rechter wèl bevoegd zou moeten zijn zich te bemoeien met de keuze van de procesvertegenwoordiger van een verdachte rechtspersoon. Zoals het een verdachte natuurlijke persoon vrij staat om ter zitting te zwijgen of zich van den domme te houden, zo zou ook een verdachte rechtspersoon vrij moeten zijn in zijn keuze voor een niet-coöperatieve proceshouding, welke proceshouding dan noodzakelijkerwijs wordt uitgedragen door de vertegenwoordiger die de rechtspersoon daarvoor het meest geschikt acht. Natuurlijk mag de rechter daar kritische vragen over stellen, maar indien de vertegenwoordiger voldoende duidelijk maakt dat hij handelt overeenkomstig de wens van de rechtspersoon - waarvan als regel ook moet worden uitgegaan - zullen de procesdeelnemers het daarmee moeten doen. Onvrede omtrent de gekozen vertegenwoordiger behoort dus geen reden te zijn voor gebruik van de bevoegdheid ex artikel 528 lid 3 Sv.

Ter relativering van het voorgaande kan overigens worden opgemerkt dat de bestuurder die op grond van artikel 528 lid 3 Sv door de rechter is bevolen te verschijnen, aldaar als (alternatieve) vertegenwoordiger aanwezig is en dus niet verplicht is de hem gestelde vragen te beantwoorden. ${ }^{79}$ De inbreuk op de vrijheid van verdediging zal zo bezien geen al te schadelijke gevolgen hoeven te hebben. ${ }^{80}$

\subsection{Reikwijdte van de vertegenwoordigingsregeling}

De regeling inzake de vertegenwoordiging van de rechtspersoon is zodanig geformuleerd dat zij betrekking heeft op de fase van de vervolging. Volgens de

77 De overheid dient zich niet te mengen in de wijze waarop de verdediging wordt gevoerd, zo stellen ook E. Prakken en T.N.B.M. Spronken in hun Inleiding van het Handboek Verdediging, $2^{\mathrm{e}}$ druk, Deventer 2009, p. I5-I6.

78 Zie art. 398 , aanhef en onder $2^{0}$, Sv en art. 48 lid I WED.

79 Zie hiervóór, onderdeel 2.4. Zie ook reeds H. de Doelder, De onderneming en de strafvordering, Account Dossier I992, nr 7, p. 22-3I, op p. 30, waar hij opmerkt dat toepassing van de bevoegdheid van de rechter ex art. 528 lid $3 \mathrm{~Sv}$ tot mislukken gedoemd is indien de betrokkenen daaraan niet wensen mee te werken en er het zwijgen toe doen.

8o Wel zij opgemerkt dat het niet-beantwoorden van vragen ter zitting de nodige irritatie kan wekken en aldus kan leiden tot een zeer moeizaam verloop van de behandeling, hetgeen niet gunstig is. 
traditionele opvatting is dat de fase waarin een rechter bij de zaak betrokken wordt, met het oog op de toepassing van vergaande dwangmiddelen ${ }^{81}$ dan wel doordat de rechtspersoon wordt gedagvaard..$^{82}$ Voor de fase die daaraan voorafgaat - de fase van strafrechtelijk onderzoek en opsporing zonder rechterlijke betrokkenheid heeft de wetgever tot op heden niet voorzien in een vertegenwoordigingsregeling. Dat valt te betreuren, want het leidt tot rechtsonzekerheid. Hoe moet de rechtspersoon reageren wanneer hij wordt geconfronteerd met onderzoekshandelingen en dwangmiddelen van opsporingsambtenaren? Wie bepaalt of, hoe en in welke mate daaraan zal worden meegewerkt? Wie kan namens de rechtspersoon toestemming geven en aldus mogelijk verdedigingsrechten prijsgeven? Wie kan in de opsporingsfase voor de rechtspersoon spreken of zwijgen?

Het lijkt praktisch de vertegenwoordigingsregeling van artikel 528 Sv van overeenkomstige toepassing te achten in de fase voorafgaand aan de vervolging. ${ }^{83}$ Daarmee zou al een aantal vragen vrij eenvoudig kunnen worden beantwoord, zoals de vraag naar het eerste aanspreekpunt binnen de rechtspersoon (antwoord: het bestuur resp. de bestuurders) en de vraag of ook anderen namens de rechtspersoon kunnen spreken of zwijgen (antwoord: de daartoe door bestuurders gemachtigden). Het ware wenselijk dat de wetgever dit met zoveel woorden zou vastleggen, maar de praktijk kan zich ook zonder die expliciete uitspraak reeds naar deze uitgangspunten richten.

Dat kan dus, maar het is geenszins gezegd dat de praktijk dat ook zal willen doen. Het is zeer wel denkbaar dat een opsporingsambtenaar meent dat hij bestuurders als getuige kan horen zolang de rechtspersoon niet kenbaar heeft gemaakt wie zijn vertegenwoordiger is, terwijl hij tevens meent dat die keuze pas in de vervolgingsfase aan de orde kan zijn. Zo geredeneerd heeft hij 'vrij spel' in de opsporingsfase en is er dan in die fase geen vertegenwoordiger die een cautie moet krijgen, zoals in de vervolgingsfase wel het geval is. In deze lijn van denken is zelfs mogelijk de rechtspersoon het zwijgrecht in de opsporingsfase geheel en al te ontzeggen, om de eenvoudige reden dat er dan nog niemand aangewezen is die dat recht zou kunnen uitoefenen, nu artikel $528 \mathrm{~Sv}$ formeel nog niet van toepassing is. ${ }^{84}$

Deze laatste benadering lijkt mij echter onhoudbaar. Men kan de verdedigingsrechten van een verdachte rechtspersoon toch niet buiten de deur houden op grond van de toevallige omstandigheid dat de wetgever de vertegenwoordigingsregeling beperkt heeft geformuleerd? Ik spreek hier van een toevallige omstandigheid,

8I Zoals het vorderen van een rechterlijke machtiging voor - bijvoorbeeld - het leggen van conservatoir beslag, het doen van een doorzoeking, het instellen van een strafrechtelijk financieel onderzoek of het opnemen van vertrouwelijke communicatie.

82 Zie G.J.M. Corstens, Het Nederlands strafprocesrecht, $8^{\mathrm{e}}$ druk, bewerkt door M.J. Borgers, Deventer 20I4, p. 9I, waar het begrip vervolging in algemene zin wordt gedefinieerd als: het uitlokken door een vervolgingsambtenaar van een onderzoek of een beslissing van de rechter.

83 In dezelfde zin A.L.J. van Strien in: Melai c.s., Wetboek van Strafuordering (losbl.), aant. 6.I en aant. I6 bij art. 528 Sv (suppl. I6I, juni 2007).

84 In deze zin expliciet R.A. Torringa, Strafbaarheid van rechtspersonen, diss. Groningen, Arnhem I984, p. I35, die vreesde voor bewijsmoeilijkheden indien de vertegenwoordigingsregeling van artikel $528 \mathrm{~Sv}$ wel analoog zou worden toegepast op de opsporingsfase. Vgl. ook J. Wortel, De onderneming in het strafrecht, Lelystad I987, p. 95-96, alsmede N. Jörg, Strafbare rechtspersonen in Amerika, Arnhem I990, p. I42. 
omdat immers uit niets blijkt dat de verwijzing naar de vervolgingsfase ooit bewust is gekozen om de rechtspersoon in de opsporingsfase 'onmondig' te houden. De wetgever heeft slechts voortgeborduurd op de initiële regeling uit het Economisch Sanctiebesluit I94I en de terminologie nimmer aangepast. Het onbedoeld tekortschieten van de nationale wetgever op dit punt is geen grond de rechtspositie van de verdachte rechtspersoon ver achter te stellen ten opzichte van die van de verdachte natuurlijke persoon (die van ontoereikende vertegenwoordigingsregels geen hinder ondervindt). Indien zij daarvoor in aanmerking komen, behoren de verdedigingsrechten uit hoofde van het Wetboek van Strafvordering onverkort te kunnen worden uitgeoefend door verdachte rechtspersonen op gelijke wijze als door verdachte natuurlijke personen. En dat geldt evenzeer voor de verdedigingsrechten uit hoofde van het EVRM..$^{85}$

Aan het voorgaande kan verder worden toegevoegd dat het ontbreken van een strafvorderlijke vertegenwoordigingsregeling voor de opsporingsfase natuurlijk niet betekent dat een rechtspersoon dan niet kan spreken of zwijgen. De rechtspersoon neemt ook tijdens die fase gewoon deel aan het maatschappelijk verkeer en laat zich daarin vertegenwoordigen door zijn bestuur en zijn bestuurders, overeenkomstig het wettelijk regime van Boek 2 BW. Het ligt duidelijk meer in de rede om bij het ontbreken van een specifieke vertegenwoordigingsregeling terug te vallen op de algemene vertegenwoordigingsregeling dan om te doen alsof er geen vertegenwoordiger is. Wie een analoge toepassing van artikel $528 \mathrm{~Sv}$ voor de opsporingsfase afwijst, zal rechtens dan ook zijn aangewezen op de regeling uit het Burgerlijk Wetboek die helder doet uitkomen dat de bestuurders van de rechtspersoon als zijn vertegenwoordigers zijn aan te merken.

\section{I3 Zwijgrecht en cautieplicht bij verhoor van bestuurders}

Naar mijn oordeel behoort het voorschrift van artikel $29 \mathrm{~Sv}$ in relatie tot de rechtspersoon in de opsporingsfase 'gewoon' in acht te worden genomen, door in elk geval de bestuurders van een verdachte rechtspersoon de cautie te geven indien zij worden verhoord. Of de bestuurder in kwestie door de opsporingsambtenaar nu ook zelf wordt aangemerkt als verdachte of 'slechts' als getuige, zou niet maatgevend moeten zijn. Gegeven de algemene vertegenwoordigingsbevoegdheid van de bestuurders moet namelijk worden aangenomen dat hun verklaring, ook wanneer die volgens het proces-verbaal van verhoor als getuige is afgelegd, materieel (mede) zal gelden als verklaring van de rechtspersoon, dan wel inhoudelijk aan de rechtspersoon zal worden toegerekend. Hier domineert de vertegenwoordiger-status. De bestuurder moet daarom ook de cautie krijgen als hij zelf geen verdachte is. De cautie strekt ertoe hem als wettelijk bevoegde vertegenwoordiger te behoeden voor een ongewilde medewerking aan de veroordeling van de verdachte rechtspersoon die hij als bestuurder qualitate qua kan vertegenwoordigen. ${ }^{86}$

85 Zie ook hierna, onderdeel 4.I e.v.

86 Vgl. HR I3 oktober I98I, NJ I982, I7. 
Door het onterecht achterwege blijven van de cautie wordt een belangrijk strafvorderlijk voorschrift in aanzienlijke mate geschonden, mede in aanmerking genomen dat de mededeling aan de verdachte dat hij niet verplicht is tot antwoorden, noodzakelijk is ter verzekering van het recht van de verdachte op een eerlijk proces in de zin van art. 6 EVRM. ${ }^{87}$ Met die laatste toevoeging wordt expliciet de verbinding aangebracht met de verdragsbepaling. Dat ligt ook in de rede, omdat de cautie bevordert dat de verdachte zijn 'right to remain silent and not to contribute to incriminating himself' zal kunnen effectueren. Dat is van essentieel belang, gegeven de kwalificatie van deze rechten als 'generally recognised international standards which lie at the heart of the notion of a fair procedure under Article 6'.

Wanneer de verdachte een rechtspersoon is, zullen zijn rechten in dezen feitelijk moeten worden geëffectueerd door de natuurlijke personen die in zijn organisatie werkzaam zijn, waarbij de bestuurders als wettelijk vertegenwoordigers voorop staan. Gelet op de strekking van artikel 29 lid 2 Sv en het grote gewicht dat wordt toegekend aan de naleving van dit voorschrift, kan niet worden aanvaard dat in een opsporingsonderzoek tegen een rechtspersoon de cautie achterwege blijft indien de bestuurders worden gehoord.

\section{I4 Gemachtigden}

In de vertegenwoordigingsregeling wordt de bestuurder centraal gesteld. Hij is de eerst aangewezene om de rechtspersoon te vertegenwoordigen en de rechter kan zijn persoonlijke verschijning bevelen, zo nodig zelfs zijn medebrenging gelasten. Zolang dat laatste niet aan de orde is, kan de bestuurder echter ook bij gemachtigde verschijnen. In de praktijk komt dit laatste veelvuldig voor, vooral bij rechtspersonen met een omvangrijke organisatiestructuur.

Het mogelijk optreden als gemachtigde van de bestuurder die is aangewezen om de verdachte rechtspersoon vertegenwoordigen, is volgens de letter van de wet beperkt tot de vervolgingsfase. Dat krijgt hier nog wat meer accent dan bij de bestuurder, omdat de wet expliciet spreekt van het 'bij gemachtigde verschijnen' van de vertegenwoordiger, hetgeen vooral doet denken aan het verschijnen ter terechtzitting en mogelijk ook aan het verschijnen voor verhoor voor een rechter-commissaris.

Ook hier is evenwel denkbaar de regeling analoog toe te passen op de opsporingsfase. Mits voldoende aannemelijk is dat het optreden van de gemachtigde bevoegdelijk plaatsvindt, is er weinig op tegen de rechtspersoon ad hoc zijn vertegenwoordiger te laten kiezen teneinde voor hem op te treden en zijn belangen te behartigen in het strafrechtelijk onderzoek. Die vrijheid heeft de rechtspersoon ook elders in het rechtsverkeer - in de context van civielrechtelijke en bestuursrechtelijke procedures - en zij past bij het eerder aangehaalde principe van verdedigingsvrijheid.

In beginsel kan een ieder als gemachtigde optreden. De gemachtigde kan iemand zijn die werkzaam is ten behoeve van de verdachte rechtspersoon, maar bijvoorbeeld ook een functionaris van een houdstermaatschappij of een extern adviseur. Ook een advocaat kan als gemachtigde vertegenwoordiger optreden, maar dan kan

87 Aldus nog vrij recent HR I6 april 2013, NJ 2013, 310, m.nt. B.F. Keulen. 
hij niet meer tegelijkertijd als raadsman fungeren. ${ }^{88}$ Deze hoedanigheden zijn niet verenigbaar en moeten dan ook goed worden onderscheiden. Een verklaring van een advocaat die als gemachtigde vertegenwoordiger optreedt, geldt als bewijsmiddel, omdat deze moet worden aangemerkt als een verklaring van de verdachte. ${ }^{89}$ Een verklaring van een advocaat die als raadsman optreedt, levert geen wettig bewijsmiddel op en kan dus niet voor het bewijs worden gebruikt. ${ }^{\circ}$

De wet stelt verder geen eisen aan de wijze waarop de machtiging moet geschieden, zodat in voorkomend geval ook een mondelinge machtiging toereikend kan worden geacht. ${ }^{91}$ Indien ter zitting iemand verschijnt die desgevraagd verklaart geen advocaat te zijn en ook geen bestuurder van de verdachte rechtspersoon, maar die in de zaak tegen de rechtspersoon duidelijk wel het woord wil voeren, zal de rechter ambtshalve moeten onderzoeken of deze persoon als gemachtigde van de bestuurder(s) is verschenen. ${ }^{92}$ Het enkele feit dat iemand geen machtiging kan overleggen of niet spontaan verklaart te zijn gemachtigd, is op zichzelf nog geen reden om te concluderen dat de verdachte rechtspersoon niet vertegenwoordigd is. ${ }^{93}$

De gemachtigde kan niet worden onderworpen aan een bevel tot persoonlijke verschijning. Indien de gemachtigde na een eerste behandeling op de vervolgzitting niet meer komt opdagen, terwijl er evenmin een (gemachtigd) raadsman is, staat de rechter in zekere zin met lege handen. Voor die situatie biedt de voorziening van artikel 528 lid $3 \mathrm{~Sv}$ een oplossing, omdat bij gebreke van een vertegenwoordiger - na aanvankelijke verschijning - onduidelijkheid kan bestaan over de procesopstelling van de rechtspersoon. Onder die omstandigheden bestaat weinig bezwaar tegen de toepassing van de rechterlijke bevoegdheid alsnog een bestuurder te doen verschijnen.

In de literatuur is erop gewezen dat ook de keuze voor de gemachtigde kan worden beïnvloed door het feit dat de gemachtigde als vertegenwoordiger niet meer als getuige kan optreden. De verdachte rechtspersoon zou zo dus niet alleen bestuurders, maar ook andere werknemers of betrokkenen als getuige kunnen 'uitschakelen' en als gemachtigde vertegenwoordiger gebruik kunnen laten maken van het zwijgrecht. 94

88 Vgl. o.a. HR 25 april I989, NJ I990, 9I, m.nt. G.J.M. Corstens.

89 Zie hiervóór, onderdeel 2.3.

90 Zie HR 8 januari 2002, NJ 2002, 340, m.nt. T.M. Schalken. Het ging hier overigens om een gemachtigd raadsman: gemachtigd tot het voeren van de verdediging in de hoedanigheid van raadsman, maar niet gemachtigd tot vertegenwoordiging in de hoedanigheid van vertegenwoordiger van de rechtspersoon. Zie voorts HR I5 december 2009, NJ 20I0, 26.

9I Zie HR 20 maart I990, NJ I99I, 8, m.nt. Th.W. van Veen.

92 Zie HR I4 september 20I0, ECLI:NL:HR:20I0:BM8027. In deze zaak had het hof een ter zitting verschenen lid van het managementteam (niet zijnde bestuurder) zonder nader onderzoek naar de publieke tribune verwezen en verstek verleend tegen de niet-verschenen verdachte rechtspersoon. De Hoge Raad ging daar niet mee akkoord.

93 De rechter zal een dergelijke conclusie niet te snel mogen trekken, nu hier het aanwezigheidsrecht van de verdachte in het geding is, zoals dat ook voor de rechtspersoon uitdrukking heeft gevonden in art. 6 EVRM, aldus de CAG (Vellinga) bij het zojuist aangehaalde arrest van HR I4 september 20I0, ECLI:NL:HR:20I0:BM8027.

94 Zie o.a. J. Wortel, De onderneming in het strafrecht, Lelystad I987, p. 94, die spreekt van 'een procestruc'. 
Of dit een reëel fenomeen is, waag ik te betwijfelen, maar het zou op zichzelf natuurlijk best kunnen worden onderzocht. De vertegenwoordigingsregeling functioneert al decennialang en er zullen dus genoeg ervaringsgegevens zijn om een stevig empirisch onderzoek op los te laten. Op voorhand zou ik echter menen dat het wel meevalt met dat 'uitschakelen' door aanwijzing als gemachtigde. Het is voor een verdachte rechtspersoon namelijk bepaald niet zonder risico's om een willekeurige werknemer - niet zijnde een bestuurder - als gemachtigde aan te stellen, teneinde hem als getuige buiten spel te plaatsen. Bepaald niet elke werknemer die uit hoofde van betrokkenheid bij mogelijk strafbaar gedrag als getuige toevallig 'belangrijk' is, zal ook in staat zijn de delicate belangen van de verdachte rechtspersoon in het strafproces adequaat te behartigen. ${ }^{95}$ En dan moet de verdachte rechtspersoon dus maar afwachten hoe sterk deze vertegenwoordiger in zijn schoenen staat en hoe verstandig deze zal opereren. Dat is minder aantrekkelijk dan wel wordt voorgesteld.

Los daarvan gaat het hier om gemachtigde niet-bestuurders, die hun kennis veeleer zullen ontlenen aan feitelijke betrokkenheid dan aan functionele verantwoordelijkheid. Als getuige zouden dergelijke personen vermoedelijk al snel een beroep kunnen doen op het verschoningsrecht van artikel 2I9 Sv, zo zij al niet de cautie zouden moeten krijgen op grond van verdenkingen in hun richting, zodat de vraag gewettigd is of de bedoelde 'procestruc' nu wel zoveel zou kunnen toevoegen. Ook op grond daarvan mag worden betwijfeld dat dit vaak voorkomt.

\section{Toestemming en medewerkingsverplichtingen}

\section{I Toestemming}

Het is mogelijk dat een (rechts)persoon toestemming verleent tot het verrichten van bepaalde onderzoekshandelingen, ofschoon deze inbreuk maken op zijn rechten. In dat geval kan de toepassing van dwangmiddelen of onderzoeksbevoegdheden achterwege blijven. In beginsel hoeft het overheidsoptreden dan ook niet meer te worden getoetst aan de wettelijke voorwaarden die zouden gelden voor de formele bevoegdheidsuitoefening. Dat betekent dat een strafvorderlijk overheidsoptreden dat berust op toestemming in voorkomend geval verder kan gaan dan waartoe een wettelijke regeling zou legitimeren: aan de verdenkingsvoorwaarde hoeft niet te zijn voldaan en zelfs buitenwettelijke onderzoeksmiddelen kunnen worden ingezet. Een en ander werd reeds expliciet aanvaard in de befaamde Bloedproef-arresten..$^{6}$ Daarin oordeelde de Hoge Raad dat ingrepen die verder gaan dan de bevoegdheden uit het Wetboek van Strafvordering toestaan, toch als rechtmatig kunnen worden beschouwd indien zij geschieden met toestemming. In een later arrest ${ }^{97}$ werd algemeen overwogen:

95 Vgl. ook A.L.J. van Strien in: Melai c.s., Wetboek van Strafvordering (losbl.), aant. 7.3 bij art. $528 \mathrm{~Sv}$ (suppl. I6I, juni 2007), die ervan uitgaat dat de gemachtigde toch vaak zal worden gekozen op grond van diens persoonlijke kwaliteiten.

96 Zie HR 5 juni I95I, NJ I95I, 520 en HR 26 juni I962, NJ I962, 470, beide m.nt. W. Pompe.

97 Zie HR ir juni I996, NJ I996, 688. 
'(...) het gebruik van dwangmiddelen (...) houdt weliswaar een inbreuk in op grondrechten die een wettelijke legitimatie behoeft, doch aan de wettelijke vereisten behoeft niet te zijn voldaan in geval van toestemming van degene aan wie het betreffende grondrecht toekomt.'

Toestemming kan derhalve fungeren als een legitimatie van overheidsoptreden dat anders niet rechtmatig zou zijn. ${ }^{98}$ Indien eenmaal vaststaat dat toestemming is gegeven, zal de rechter in de regel niet meer toekomen aan een toetsing van het optreden. Vanuit het perspectief van de verdediging bezien, doet de (rechts)persoon die toestemming verleent tot strafvorderlijk overheidsoptreden bij voorbaat ${ }^{99}$ afstand van rechten: hij aanvaardt de inbreuk en ziet af van rechtsbescherming. Dat kan belangrijke consequenties hebben voor de rechtspositie van de betrokken (rechts-) persoon: consequenties die deze ten tijde van de beslissing wellicht niet voor ogen had. Vandaar dat niet te gemakkelijk mag worden aangenomen dat toestemming is verleend.

Onder verwijzing naar rechtspraak van het EHRM inzake het afstand doen van verdedigingsrechten kan allereerst als voorwaarde worden gesteld dat de toestemming op ondubbelzinnige wijze is verleend en dat zij 'must be attended by minimum safeguards commensurate to its importance', waarbij te denken is aan een adequate schriftelijke vastlegging. Dat laatste kan ook discussies over de reikwijdte van de gegeven toestemming voorkomen. ${ }^{\text {100 }}$

Voorts zal sprake moeten zijn geweest van vrije wilsbepaling door degene die de toestemming gaf. ${ }^{\text {ro }}$ Wanneer de toestemming kennelijk is verleend onder druk van de mogelijke inzet van dwangmiddelen, mag niet worden aangenomen dat de betrokkene vrijwillig heeft ingestemd met de inbreuk waarvoor hij toestemming gaf. ${ }^{\text {Io2 }}$ Dan zal de rechter wel degelijk moeten toetsen of aan de wettelijke - en verdragsrechtelijke - vereisten is voldaan en kan aan de gegeven toestemming dus geen legitimerende kracht worden toegekend.

98 Zie ook Y.G.M. Baaijens-van Geloven en J.B.H.M. Simmelink, 'Normering van de opsporing', in: M.S. Groenhuijsen en G. Knigge (red.), Dwangmiddelen en Rechtsmiddelen, Derde interimrapport onderzoeksproject 2001, Deventer 2002, p. 437-598, i.h.b. p. 469-483. Zij beschouwen de rechtvaardigende werking van de vrijwillige medewerking door de burger aan de opsporing als een ongeschreven hoofdregel, waarvan de uitwerking kan worden overgelaten aan de jurisprudentie (a.w., p. 474).

99 In de regel gaat het om toestemming vooraf, maar ook achteraf kan de verdachte nog worden gevraagd om 'alsnog' toestemming te verlenen, zoals blijkt uit HR 6 januari 2015, NJ 2015, I09, m.nt. T.M. Schalken. In een dergelijke situatie kan de toestemming ertoe leiden dat aan een vormverzuim geen sanctie wordt verbonden.

Ioo Zie daarover ook J.M. Reijntjes, 'Het prijsgeven van rechten', Strafblad 2008, p. 547-559, op p. 555.

IoI Waarbij de betrokkene uiteraard ook wel in staat moet zijn geweest tot vrije wilsbepaling. Vgl. HR I6 september 1985 , NJ I986, 232: toestemming is niet verleend wanneer aannemelijk is dat de desbetreffende verklaring van de verdachte als gevolg van een stoornis van zijn geestvermogens niet in overeenstemming met zijn wil is.

I02 Zie reeds EHRM 27 februari I980 (Deweer), Appl. nr 6903/75, waarin werd geoordeeld dat 'Mr Deweer's waiver of a fair trial (...) was tainted by constraint'. Zie voorts EHRM I4 september 2010 (Sanoma Uitgevers BV), NJ 20II, 230, m.nt. E.J. Dommering en T.M. Schalken (par. 68-70), alsmede EHRM I8 april 2013 (Saint-Paul Luxembourg SA), in par. 38. Zoals ook hierna nog aan de orde zal komen, hecht het EHRM terecht veel waarde aan 'respecting the will of an accused person'. Zie m.n. EHRM I7 december 1996 (Saunders), NJ 1997, 699, m.nt. G. Knigge (par. 69), alsmede hierna, onderdeel 4.2. 
Een vrije wilsbepaling veronderstelt ook dat de betrokkene beseft wat de consequenties zijn van het verlenen van toestemming en dat hij beseft dat hij daarmee afstand doet van rechten, alsook dat hij er zich van bewust is dat hij zijn toestemming in voorkomend geval kan weigeren en dat hem daarbij duidelijk is wat dan zijn rechten zijn. Wanneer vaststaat dat betrokkene zich van dat alles bewust was en hij vervolgens uit vrije wil zijn toestemming heeft verleend, zal sprake kunnen zijn van een 'informed consent' waardoor het optreden kan worden gerechtvaardigd. In de literatuur is in ruime mate steun te vinden voor het stellen van de eis van 'informed consent' ${ }^{103}$ maar vooralsnog is niet zeker of en in hoeverre de Hoge Raad daarin mee zal gaan. ${ }^{104}$

Van groot belang is vervolgens nog de voorwaarde dat de toestemming voor het inbreukmakend optreden moet zijn verleend door degene aan wie het grondrecht toekomt. ${ }^{105}$ Waar de rechthebbende een rechtspersoon is, mag niet worden aangenomen dat de gemiddelde werknemer bevoegd is te bepalen of - door het verlenen van toestemming - afstand zal worden gedaan van fundamentele rechten. De toestemming zal hier op ondubbelzinnige wijze moeten worden verleend door iemand die bevoegd is hierover namens de rechtspersoon te beslissen, dus in de regel het bestuur, een bestuurder of een door deze ad hoc gemachtigde.

Meer concreet betekent dit dus dat de portier of receptionist die de deur opent voor een of meer opsporingsambtenaren en deze vervolgens niet verhindert door te lopen, daarmee nog niet namens de rechtspersoon heeft ingestemd met een bedrijfsbezoek. Hetzelfde geldt ingeval de doorgelopen opsporingsambtenaren een aanwezige werknemer mededelen dat zij onderzoek komen doen naar de naleving van bepaalde wetgeving en op de vraag of daar bezwaar tegen bestaat van die werknemer een antwoord krijgen als 'Gaat uw gang dan maar' of woorden van gelijke strekking. In die uitlating ligt geen vrijbrief besloten voor onderzoek dat

I03 Zie M.J. Borgers in zijn annotatie bij HR I8 december 20I2, NJ 20I3, 355, met nadere bronvermelding.

I04 Zie de kritische analyse van P.T.C. van Kampen, “Informed consent” en de rechtspraak ex artikel 359a Sv', DD 2013, I5, p. I40-I55. Zie voorts meer algemeen B.F. Keulen en G. Knigge, Strafprocesrecht, $\mathrm{I}_{2}{ }^{\mathrm{e}}$ druk, Deventer 2010, p. 303, alsmede G.J.M. Corstens, Het Nederlands strafprocesrecht, 8 druk, bewerkt door M.J. Borgers, Deventer 20I4, p. 4I3. In de context van afstand doen van het recht op rechtsbijstand eist de Hoge Raad in elk geval wel dat de rechter zich ervan zal moeten vergewissen dat de afstand 'ondubbelzinnig, desbewust en vrijwillig' is gedaan. Zie m.n. HR I7 november 2009, NJ 20I0, I43, m.nt. T.M. Schalken. Bij wijze van illustratie zij nog vermeld dat op het terrein van het bestuursrecht de eis van 'informed consent' hier en daar nadrukkelijk doorklinkt in de rechtspraak. Zie recent bijvoorbeeld CRvB 2I april 2015, ECLI:NL:CRVB:2015:1287, waarin wordt overwogen: 'Volgens vaste rechtspraak (...) is geen sprake van inbreuk op het huisrecht als bedoeld in deze verdragsbepaling [art. 8, eerste lid, EVRM, DD] als de rechthebbende toestemming heeft gegeven voor het binnentreden in de woning. De toestemming moet vrijwillig zijn verleend en op basis van "informed consent". Dit houdt in dat de toestemming van de betrokkene berust op volledige en juiste informatie over de reden en het doel van het huisbezoek en over de gevolgen die het weigeren van toestemming (...) heeft.' De bewijslast ten aanzien van het 'informed consent' bij het binnentreden in de woning rust volgens deze vaste rechtspraak op het bestuursorgaan. Zie over deze rechtspraak ook P.A.M. Mevis, 'De bescherming van de woning 25 jaar later', in: E.J. Hofstee, O.J.D.M.L. Jansen en A.M.G. Smit (red.), Kringgedachten, Opstellen van de Kring Corstens, Deventer 20I4, p. I57-I70, op p. I68.

I05 Deze voorwaarde komt expliciet tot uitdrukking in de zojuist geciteerde overweging uit HR II juni I996, NJ I996, 688. Vgl. ook reeds HR NJ I95I, 520 ('iemand, die daarover vermag te beschikken'). 
een inbreuk maakt op de rechten van de rechtspersoon, omdat degene aan wie de rechten toekomen - de rechtspersoon dus - voor die inbreuk geen toestemming heeft gegeven.

Tegenover deze terughoudende benadering zou gesteld kunnen worden dat gedragingen en uitlatingen van individuele werknemers toch veelal kunnen worden toegerekend aan de rechtspersoon, zodat niet erg relevant zou zijn of de werknemer in kwestie nu ook formeel bevoegd of gemachtigd is namens de rechtspersoon afstand te doen van diens rechten. Met de criteria voor het vaststellen van daderschap zou ook de vraag naar toestemming of vrijwillige medewerking kunnen worden beantwoord. Dat lijkt mij echter duidelijk minder goed verdedigbaar. Afstand doen van rechten heeft het karakter van een rechtshandeling door de rechtspersoon en daarbij past een meer formele benadering.

\subsection{Medewerkingsverplichtingen}

In de voorgaande paragraaf stond de vraag centraal onder welke omstandigheden mag worden aangenomen dat een rechtspersoon zijn vrijwillige medewerking verleent of heeft verleend aan onderzoeksverrichtingen van opsporingsambtenaren. Een rechtspersoon heeft echter lang niet altijd de keuze om al dan niet vrijwillig mee te werken aan strafrechtelijk onderzoek. Vooral op het terrein van de bijzondere strafwetgeving bestaan ruim geformuleerde medewerkingsverplichtingen. Zo bepaalt artikel 24a WED dat een ieder verplicht is aan de opsporingsambtenaren alle medewerking te verlenen die deze redelijkerwijs kunnen vorderen bij de uitoefening van hun opsporingsbevoegdheden. Uit de rechtspraak kan worden afgeleid dat dergelijke niet nader geclausuleerde medewerkingsverplichtingen in de bijzondere strafwetgeving zich ook tot de verdachte uitstrekken. ${ }^{\text {106 }}$

Dit laatste is niet vanzelfsprekend. In het Wetboek van Strafvordering zijn juist diverse bepalingen te vinden die een uitdrukkelijk verbod inhouden een verdachte te dwingen tot actieve medewerking aan de opsporing. De reikwijdte van medewerkingsverplichtingen in het wetboek is in de regel beperkt tot derden; van de verdachte wordt veelal slechts gevergd dat hij de ingezette dwangmiddelen niet actief tegenwerkt. Hij zal de uitoefening moeten dulden.

Wanneer het gaat om inbeslagneming van voorwerpen, mag een bevel tot uitlevering worden gericht tot de vermoedelijke houder daarvan, maar niet tot de verdachte. ${ }^{107}$ Wanneer het gaat om onderzoek in geautomatiseerde werken, mag een bevel tot toegang c.q. ontsleuteling worden gericht tot degene van wie redelijkerwijs kan worden vermoed dat hij kennis draagt van de wijze van beveiliging, maar niet tot de

Io6 Zie in dat verband HR 20 maart I984, NJ I984, 547, m.nt. Th.W. van Veen (bevel uitlevering ex art. 52 WWM aan verdachte); HR 29 oktober 1996, NJ 1997, 232, m.nt.T.M. Schalken (bevel uitlevering ex art. 8I AWR aan verdachte); HR 2I oktober 1997, NJ I998, I73 (vordering inzage ex art. I9 WED aan verdachte); HR NJ 200I, 5 Io (bevel uitlevering ex art. 9 Opiumwet aan verdachte). De medewerkingsverplichting wordt dan overigens wel begrensd door artikel 6 EVRM, zodat in het bijzonder 'wilsafhankelijk' materiaal door een verdachte ten aanzien van wie sprake is van een 'criminal charge' niet hoeft te worden verstrekt. Zie in dat verband o.a. HR 2I december 20I0, NJ 20II, 425, m.nt. J.M. Reijntjes, gevolgd door Hof ‘s-Gravenhage 5 december 2014, NJ 2015, IIo.

I07 Zie art. 96 a Sv. 
verdachte. ${ }^{108}$ En ook de diverse vorderingen tot het verstrekken van gegevens mogen niet worden gericht tot de verdachte. ${ }^{\text {I09 }}$

Indien de verdachte een rechtspersoon is, doen zulke bepalingen de vraag rijzen of het toelaatbaar is een bevel of vordering tot medewerking te richten tot de werknemers van de rechtspersoon die zelf niet verdacht zijn. Wordt op die manier de rechtsbeschermende werking van de bedoelde bepalingen voor de rechtspersoon niet illusoir gemaakt?

Een concreet voorbeeld is het bevel tot ontsleuteling van de beveiliging van geautomatiseerde werken dat wordt gericht tot de systeembeheerder van de verdachte rechtspersoon. Moet deze werknemer in dit opzicht niet worden gezien als vertegenwoordiger van de rechtspersoon, zodat in wezen het bevel - in weerwil van het wettelijk verbod - wel degelijk wordt gericht tot de verdachte?

Uit de wetsgeschiedenis blijkt dat de regering deze vraag destijds ontkennend heeft beantwoord. Zij stelde namelijk:

\begin{abstract}
'Indien de verdachte een rechtspersoon is, kan het bevel niet tot de rechtspersoon als zodanig worden gericht, doch wel aan personen in dienst van deze rechtspersoon. Zouden deze personen zich door nakoming van dit bevel blootstellen aan een strafrechtelijke vervolging, bij voorbeeld in verband met artikel 51, tweede lid, onder $2^{\circ}$, van het Wetboek van Strafrecht [de aansprakelijkheid ter zake van opdracht geven en feitelijke leiding geven, DD], dan kunnen zij zich ingevolge het tweede lid, in verband met de artikelen 106 en 219, verschonen. ${ }^{\text {'Iо }}$
\end{abstract}

De bescherming tegen zelfincriminatie wordt hier aldus strikt beperkt tot de persoon aan wie het bevel wordt gegeven. Een reeds verdacht persoon wordt beschermd door het wettelijk verbod een bevel tot hem te richten, een nog niet verdacht persoon wordt beschermd door het 'nemo tenetur-verschoningsrecht' uit hoofde van artikel 2I9 Sv. ${ }^{\text {II }}$ Op het eerste gezicht lijkt dit logisch. Indien echter wordt bedacht dat een rechtspersoon niet anders kan handelen en verklaren dan door middel van natuurlijke personen, wier gedrag en kennis wordt toegerekend aan de rechtspersoon, is het minder logisch.

In materieel-strafrechtelijke zin mag het gedrag en de kennis van de systeembeheerder worden toegerekend aan de rechtspersoon, als ware het zijn eigen gedrag en zijn eigen kennis. Dat is een vorm van identificatie: het gedrag en de kennis van de werknemer hebben tevens te gelden als het gedrag en de kennis van de rechtspersoon. Gelet op die identificatie zou het weinig consequent zijn om de rechtspersoon en zijn systeembeheerder in strafprocesrechtelijke zin te ontkoppelen en te beschouwen als gescheiden rechtssubjecten. De opsporingsambtenaar die de systeembeheerder van een verdachte rechtspersoon benadert, benadert realiter geen 'derde' maar richt zich tot een belangrijke functionaris binnen de organisatie van de verdachte rechtspersoon.

Io8 Zie art. $125 \mathrm{k} \mathrm{Sv}$.

Io9 Zie art. I26na t/m art. I26ni Sv.

IIo Zie Kamerstukken II I989/90, 2I 55I, nr 3, p. 28.

III Zie daarover hiervóór, onderdeel 2.7. Ten tijde van de geciteerde uitlating werd het 'nemo teneturverschoningsrecht' van toepassing verklaard in artikel ro6 lid 2 sub $3^{0} \mathrm{~Sv}$. Zie thans artikel ro5 lid $3 \mathrm{j}^{0} 96 \mathrm{a}$ lid 3 sub c Sv. 
In wezen benadert hij daarmee nog steeds die rechtspersoon: de systeembeheerder ontleent zijn bevoegdheden, zijn mogelijkheden tot relevant gedrag met betrekking tot de geautomatiseerde werken van de rechtspersoon en zijn kennis daaromtrent, rechtstreeks aan zijn verbondenheid met de rechtspersoon. Wanneer de systeembeheerder wordt gedwongen de beveiliging van de computer(bestanden) op te heffen en aldus toegang te verschaffen tot de geautomatiseerde omgeving van de verdachte rechtspersoon, wordt dus een functionaris binnen de verdachte rechtspersoon gedwongen tot handelen en informatieverschaffing aan derden, waarmee uiteindelijk de medewerking van de rechtspersoon is afgedwongen. Van het wettelijk vastgelegde uitgangspunt dat een verdachte niet mag worden gedwongen actief mee te werken aan het onderzoek in zijn geautomatiseerde werken, blijft dan per saldo niets over.

De aangehaalde passage uit de Memorie van Toelichting is intussen ruim vijfentwintig jaar oud. Het denken over de strafrechtelijke positie van de rechtspersoon is inmiddels voortgeschreden: zowel op het terrein van het materiële strafrecht als op het terrein van het strafprocesrecht hebben zich belangrijke ontwikkelingen voorgedaan. Ik noem de jurisprudentiële verduidelijking en verruiming van de daderschapscriteria en de jurisprudentiële erkenning van de verdedigingsrechten van rechtspersonen in de context van het EVRM. Tegen deze achtergrond bezien, valt uitstekend te verdedigen dat de wettekst een uitleg toelaat die meer recht doet aan het uitgangspunt dat daaraan ten grondslag ligt, ook al verwijdert zij zich dan van de aangehaalde passage uit de wetsgeschiedenis. Dat is de uitleg die erop neerkomt dat een bevel als bedoeld in artikel $125 \mathrm{k}$ Sv niet mag worden gericht tot mensen die duidelijk werkzaam zijn 'in de sfeer' van de verdachte rechtspersoon. In die uitleg zou het bevel niet gegeven mogen worden aan de interne systeembeheerder van de verdachte rechtspersoon. Hooguit zou (het bestuur van) de rechtspersoon kunnen worden verzocht toestemming te verlenen voor het onderzoek.

De consequentie van deze uitleg zou zijn dat het onder omstandigheden moeilijker wordt om toegang te verkrijgen tot beveiligde computers en gegevensbestanden. Die consequentie lijkt evenwel te moeten worden aanvaard, nu dat immers ook het geval is wanneer de verdachte een natuurlijk persoon is. De belangen die zijn gemoeid met het verkrijgen van toegang tot de computer van een verdachte natuurlijke persoon zijn op zichzelf niet minder zwaarwegend dan de belangen die zijn gemoeid met het verkrijgen van toegang tot het computersysteem van een rechtspersoon. Wel kan de hoeveelheid data die aldus moeilijker toegankelijk wordt, getalsmatig al snel groter zijn naarmate de organisatie van de rechtspersoon omvangrijker is. Dat doet echter niet af aan het principe.

Overigens wordt gewerkt aan wetgeving die voor bepaalde gevallen - namelijk wanneer het gaat om grootschalige kinderpornografie of om terroristische misdrijven - een uitzondering wil toestaan op het principe dat het decryptiebevel niet mag worden gericht tot een verdachte. ${ }^{\mathrm{II} 2}$ Die uitzondering is echter bepaald omstreden en bevestigt voorlopig slechts de kracht van de regel.

Zie het ontwerp-wetsvoorstel Computercriminaliteit III, kritisch besproken door M. Buwalda en N. Kwakman, 'Het decryptiebevel en het nemo-teneturbeginsel', AA 20I4, nr I, p. 9-I7. Het definitieve wetsvoorstel wordt volgens de Minister van Veiligheid en Justitie in september 2015 aan de Tweede Kamer aangeboden; zie Kamerstukken II 20I4/I5, 28 684, nr 443. 


\section{$4 \quad$ Fundamentele rechten van de rechtspersoon in het strafproces}

\section{I Rechtspersonen en fundamentele rechten}

Wanneer de rechtspersoon wordt erkend als volwaardig rechtssubject, is het vrij vanzelfsprekend dat de rechtspersoon ook aanspraak kan maken op fundamentele rechten die bescherming bieden tegen willekeurige ingrepen van de overheid. Waar de grondrechten in de Nederlandse Grondwet worden toegekend aan 'een ieder', zal ook moeten worden gedacht aan rechtspersonen: ook zij kunnen aan de grondrechtartikelen rechten en aanspraken ontlenen voor zover dat naar de aard van het betreffende grondrecht zin kan hebben. ${ }^{\text {Ir3 }}$ In de context van het EVRM geldt in wezen eenzelfde uitgangspunt. Ook aan dat verdrag kunnen rechtspersonen rechten ontlenen, over de schending waarvan zij kunnen klagen bij het EHRM. ${ }^{\mathrm{II}}{ }^{4}$ Vooral vanuit de 'rule of law'-gedachte beoogt het EHRM bescherming te bieden tegen willekeurige ingrepen en ongebreidelde machtsuitoefening door de overheid en daarbij besteedt het Hof nauwelijks aandacht aan de juridische hoedanigheid van de klager. ${ }^{115}$ Voor sommigen is het wellicht moeilijk te aanvaarden dat 'mensenrechten' ook voor rechtspersonen gelden, maar het EHRM volgt duidelijk een pragmatische koers waarbij rechtspersonen niet negatief worden gediscrimineerd. ${ }^{116}$ Dat geldt in elk geval waar het gaat om de verdedigingsrechten uit hoofde van artikel 6 EVRM $^{117}$ en dat geldt in de kern ook voor de rechten uit hoofde van artikel 8 EVRM, al heeft het Hof daar een nuance aangebracht. ${ }^{\mathrm{II} 8}$ Het argument dat bepaalde rechten niet aan rechtspersonen zouden toekomen op grond van de aard van het desbetreffende recht of de aard van de rechtspersoon zelf, blijkt gezien de rechtsontwikkeling steeds minder gewicht in de schaal te leggen. ${ }^{119}$ Als uitgangspunt zal hebben te gelden dat fundamentele rechten ook voor rechtspersonen gelden, indien en voor zover zij daarvoor in aanmerking komen. ${ }^{120}$

II3 Zie Kamerstukken II I975/76, I3 872, nr 3, p. II.

II4 Zie art. 34 EVRM, waarin wordt bepaald dat het Hof verzoekschriften kan ontvangen van ieder natuurlijk persoon, iedere niet-gouvernementele organisatie of iedere groep personen die beweert slachtoffer te zijn van een schending door een van de Hoge Verdragsluitende Partijen van de rechten die in het Verdrag of de Protocollen daarbij zijn vervat. Een rechtspersoon geldt als niet-gouvernementele organisatie in de zin van deze bepaling. Zie o.a. M. Emberland, The Human Rights of Companies, Exploring the Structure of ECHR Protection, Oxford 2008, p. 4 en 33, alsmede A.J.P. Schild, De invloed van het EVRM op het Ondernemingsrecht, diss. Leiden, Deventer 2012, p. 24.

II5 Zie M. Emberland, a.w., p. 46, alsmede A.J.P. Schild, a.w., p. 24: 'De omstandigheid dat niet alle grondrechten even relevant zijn voor rechtspersonen doet niet eraan af dat er in beginsel geen belemmeringen bestaan voor een rechtspersoon om zich met een klacht tot Straatsburg te wenden.'

II6 Zie ook M. Emberland, a.w., p. III: 'Despite initial reluctance, internal dissent and - in exceptional cases - some remaining doubt, the Court eventually settled on a surprisingly favourable view of the applicability of the rights and entitlements to corporate claimants.'

II7 Zie o.a. P.H.P.H.M.C. van Kempen, 'The Recognition of Legal Persons in International Human Rights Instruments: Protection Against, and Through, Criminal Justice?', in: M. Pieth \& R. Ivory (eds.), Corporate Criminal Liability, 20II, p. 355-389, op p. 373 e.v.

II8 Zie hierna, onderdeel 4.II.

II9 Aldus concludeerde reeds L. Timmerman in zijn preadvies voor de Nederlandse Juristen-Vereniging over de ontwikkeling van de rechtspersoon in het publiekrecht en privaatrecht, Handelingen NJV 2000-I, Deventer 2000, p. I05-I65, op p. I48.

I20 Of, zoals Van Kempen reeds stelde (a.w., p. 387): ‘(...) legal persons should be offered protection under each human right that can reasonably be applied to them'. 


\subsection{De verklaringsvrijheid van de rechtspersoon en artikel 6 EVRM}

In het voetspoor van het EHRM heeft de Hoge Raad in algemene zin erkend dat de in artikel 6 EVRM neergelegde waarborgen niet alleen voor natuurlijke personen maar ook voor rechtspersonen hebben te gelden. ${ }^{\text {22I }}$ Dat betekent onder meer dat de rechtspersoon die wordt geconfronteerd met een 'criminal charge' het recht heeft 'to remain silent and not to contribute to incriminating himself. ${ }^{122}$ Deze rechten worden door het EHRM omschreven als 'generally recognised international standards which lie at the heart of the notion of a fair procedure under Article 6'. Van groot belang hierbij is de erkenning van de vrijheid van een verdachte zijn eigen proceshouding te bepalen: de reeds eerder genoemde procesautonomie. Het zwijgrecht en de verklaringsvrijheid kunnen op die procesautonomie worden gefundeerd. ${ }^{123}$ Volgens het EHRM gaat het ook bij 'the right not to incriminate oneself' in de eerste plaats om 'respecting the will of an accused person to remain silent'. ${ }^{124}$

Tegen deze achtergrond bezien, is er geen enkele grond een verdachte rechtspersoon het zwijgrecht te ontzeggen of de reikwijdte van dat recht meer beperkt in te vullen dan bij een natuurlijk persoon het geval is. ${ }^{125}$ De verdachte rechtspersoon behoort te kunnen beschikken over verdedigingsrechten die 'practical and effective' zijn en dat geldt bij uitstek ook voor het zwijgrecht. De vraag is vervolgens hoe een rechtspersoon zijn zwijgrecht in het strafrechtelijk onderzoek kan uitoefenen, zodanig dat het inderdaad ook 'practical and effective' is. De omstandigheid dat de rechtspersoon uiteindelijk een juridisch constructie is die slechts kan spreken en zwijgen door de mensen die deel uitmaken van zijn organisatie, maakt deze vraag tot een vrij complexe aangelegenheid. ${ }^{\mathrm{I} 26}$

I2I Zie HR I juni I993, NJ I994, 52, waarin de Strafkamer aldus oordeelde. De Belastingkamer was haar hierin al voorgegaan: zie HR I7 januari I990, BNB I990, I93, m.nt. J.P. Scheltens.

I22 Zie reeds EHRM 25 februari I993 (Funke), NJ I993, 485, m.nt. G. Knigge.

I23 Zie in dat verband ook L. Stevens, Het nemo-teneturbeginsel in strafzaken: van zwijgrecht naar containerbegrip, diss. Tilburg, Nijmegen 2005, p. 53, met nadere bronvermelding.

I24 Zie EHRM I7 december 1996 (Saunders), NJ I997, 699, m.nt. G. Knigge (par. 69). Zie ook B.F. Keulen en G. Knigge, Strafprocesrecht, $\mathrm{I}_{2}{ }^{\mathrm{e}}$ druk, Deventer 20I0, p. 89-90: 'De erkenning van de verdachte als volwaardige procespartij impliceert juist dat hij in beginsel vrij is om zelf zijn processtrategie te bepalen, en dat hij zelf mag uitmaken wat hij in het belang van zijn verdediging naar voren wil brengen en waarover hij wenst te zwijgen.'

I25 Vgl. in deze zin ook J.M. Reijntjes, Nederlandse Strafuordering, $\mathrm{II}^{\mathrm{e}}$ druk, Deventer 2009, p. 56I: 'Aan de rechtspersoon komen niet minder waarborgen toe dan aan de natuurlijke persoon (...) Ook aan de door art. 6 EVRM geboden garanties wordt voor rechtspersonen niets af gedaan.' Anders nog A.L.J. van Strien in Melai c.s., Wetboek van Strafvordering (losbl.), aant. I6.I bij art. 528 Sv, Suppl. I6I (juni 2007), waar zij schrijft dat het zwijgrecht van de rechtspersoon een zwakkere basis heeft dan het zwijgrecht van de natuurlijke persoon. Die stelling komt voort uit de gedachte dat het zwijgrecht van de rechtspersoon berust op 'het beginsel omtrent de verdeling van de bewijslast'. Echter, zoals reeds is toegelicht, meen ik dat de grondslag van het zwijgrecht van de verdachte rechtspersoon - net als bij de verdachte natuurlijke persoon - gelegen is in diens procesautonomie en de eerbiediging van zijn wil c.q. verklaringsvrijheid.

I26 Zie daarover reeds D.R. Doorenbos, 'Het zwijgrecht van de rechtspersoon', Tijdschrift voor Sanctierecht \& Compliance 20I3, nr 5/6, p. I75-I8I. 


\subsection{Een positieve benadering}

In de wat oudere literatuur lijkt nog vooral de gedachte te overheersen dat een zwijgrecht aan de zijde van de rechtspersoon tot onoverkomelijke bewijsproblemen zal leiden, zodat dit zwijgrecht vooral beperkt zou dienen te blijven. Verder wordt veelal de wettelijke regeling omtrent de procesvertegenwoordiging centraal gesteld, waardoor beperkingen van die regeling in zekere zin 'doorwerken' op de reikwijdte van het zwijgrecht. Zo zou het zwijgrecht volgens sommige auteurs pas in de fase van de vervolging kunnen worden toegepast en niet reeds in de fase van de opsporing ${ }^{127}$, een benadering die verklaarbaar is vanuit de onvolkomen nationale regeling, maar niet verenigbaar met (de rechtspraak op) artikel 6 EVRM. Daarnaast is betoogd dat in de opsporingsfase uitsluitend één expliciet aangewezen (proces)vertegenwoordiger het zwijgrecht zou kunnen uitoefenen. ${ }^{128}$ Ook die stelling sluit op het eerste gezicht wel aan bij de nationale regeling, maar leidt nog niet tot het resultaat dat het zwijgrecht van de rechtspersoon 'practical and effective' is.

Naar mijn idee vergt de beantwoording van de vraag hoe een rechtspersoon zijn zwijgrecht kan 'waarmaken' een wat andere 'mindset' dan die welke in oudere literatuur naar voren komt. Hierna zal worden betoogd dat het antwoord niet moet worden gezocht in de vertegenwoordigingsregeling, maar dat dit antwoord moet worden gevonden in de wisselwerking met de rechtspraak inzake het vestigen van de aansprakelijkheid van de rechtspersoon. Het toerekenen van gedrag en kennis van werknemers aan de rechtspersoon is redelijk indien wordt aangenomen dat de rechtspersoon kan bepalen hoe zijn werknemers zich zullen gedragen en uitlaten. Omgekeerd zou het dan redelijk zijn te aanvaarden dat een verdachte rechtspersoon kan bepalen hoe en door wie van zijn werknemers er wordt verklaard of gezwegen, in de wetenschap dat ook verklaringen inhoudelijk voor zijn rekening zullen komen en dat elke werknemer die spreekt het zwijgrecht van de verdachte rechtspersoon illusoir kan maken. Wie aanvaardt dat aan elke verdachte en dus ook aan een verdachte rechtspersoon verklaringsvrijheid toekomt, moet onder ogen zien dat een rechtspersoon die vrijheid slechts zal kunnen benutten door middel van zijn werknemers. ${ }^{\mathrm{I} 9}$ De opvatting die impliceert dat werknemers zo nodig als getuige gedwongen zouden kunnen worden onder ede te verklaren in de zaak van de verdachte rechtspersoon, toont onvoldoende respect voor de vrije wilsbepaling van de verdachte rechtspersoon.

I27 Vgl. in deze zin J. Wortel, De onderneming in het strafrecht, Lelystad I987, p. 95-96.

I28 Zie o.a. J.A.W. Lensing, Het verhoor van de verdachte in strafzaken, diss. Nijmegen, Arnhem Ig88, p. I43, alsmede N. Jörg, Strafbare rechtspersonen in Amerika, Arnhem I99o, p. I42.

I29 Vgl. ook P.H.P.H.M.C. van Kempen, 'The Recognition of Legal Persons in International Human Rights Instruments: Protection Against, and Through, Criminal Justice?', in: M. Pieth \& R. Ivory (eds.), Corporate Criminal Liability, 2011, p. 355-389, op p. 376: '(...) that the authorities would have to respect the legal's person right to remain silent (...) would, in turn, imply that they must recognize that the natural representatives and employees have the right to remain silent (...)'. 


\subsection{Werknemers als bron van bewijs}

In relatie tot het zwijgrecht is het belangrijkste probleem voor de rechtspersoon gelegen in het feit dat zijn organisatie doorgaans vele mensen telt, die elk in staat zijn een stilzwijgen aan de zijde van de rechtspersoon te verbreken. Wanneer een daartoe door het bestuur aangewezen vertegenwoordiger van de rechtspersoon dit doet, zal dat niet op bezwaren stuiten, maar wanneer willekeurige werknemers dit doen, wordt het zwijgrecht ondergraven. Het is niet overdreven om te stellen dat het uiteindelijk de werknemers zijn die de facto in de hand hebben wat er overblijft van het zwijgrecht van de rechtspersoon.

Dit is bovenal een praktisch probleem. Opsporingsambtenaren zien de werknemers van een verdachte rechtspersoon als bruikbare getuigen en doen er soms alles aan om deze werknemers te kunnen horen, ook al weten zij dat de rechtspersoon daar zelf op tegen is. Terwijl de rechtspersoon tracht de woordvoering in het onderzoek te coördineren en in handen te leggen van door haar aangewezen werknemers, gaan opsporingsambtenaren daar vaak dwars tegenin door werknemers rechtstreeks en zo nodig op hun privéadres te benaderen om ze als getuigen een verklaring te doen afleggen. Waar de rechtspersoon zijn werknemers ziet als onderdeel van zijn organisatie, die binnen de grenzen van zijn zwijgrecht zouden moeten blijven, stellen de opsporingsambtenaren zich op het standpunt dat de werknemers een eigen positie hebben die losstaat van die van de rechtspersoon.

Zoals hieronder blijkt, kan dit conflict van opvattingen op verschillende manieren worden benaderd.

\subsection{Getuigplicht versus geheimhoudingsplicht}

Om te beginnen kan de rechtspersoon zijn werknemers natuurlijk in algemene zin instrueren dat zij in een strafrechtelijk onderzoek geen verklaring zullen (mogen) afleggen en opsporingsambtenaren zullen moeten doorverwijzen naar het bestuur of een nader aangeduide leidinggevende. Omdat voor getuigen en verdachten rechtens ook geen verplichting bestaat de vragen van opsporingsambtenaren te beantwoorden, zou de rechtspersoon met een dergelijke instructie zijn zwijgrecht in het opsporingsonderzoek tot op zekere hoogte kunnen waarborgen. ${ }^{130}$ De instructie zal dan uiteraard wel vroegtijdig moeten zijn gegeven, nu het bezoek van een opsporingsambtenaar in veel gevallen een onverwacht genoegen is. ${ }^{\mathrm{I} 3 \mathrm{I}}$ Niet elke rechtspersoon houdt daar rekening mee.

De zojuist bedoelde instructie zal op zichzelf geen stand houden indien de werknemer door de rechter-commissaris of op een zitting wordt gehoord als getuige

I30 Vgl. in dit verband ook J. Wortel, De onderneming in het strafrecht, Lelystad I987, p. I07. Zoals hij reeds signaleert, kunnen opsporingsambtenaren niet verhinderen dat een als getuige ondervraagde werknemer zich ter plekke in verbinding stelt met anderen, zoals een bedrijfsjurist of een bestuurder.

I3I Zoals in de inleiding werd vermeld, kan praktisch elke rechtspersoon op enig moment in zijn bestaan ongewild betrokken worden in een strafrechtelijk onderzoek. De rechtspersoon die zijn werknemers instrueert hoe te handelen ingeval er een opsporingsambtenaar op de stoep staat, beoogt daarmee enige regie te houden en rust te creëren als het erop aankomt. Dat is verstandig en de aanwezigheid van zulke instructies hoeft dan ook geenszins te duiden op een slecht geweten. 
in de zaak tegen de rechtspersoon. Als getuige zal hij verplicht zijn naar waarheid te verklaren, behoudens de mogelijkheid een verschoningsrecht in te roepen. De getuige die niet voldoet aan zijn verplichtingen, is strafbaar. ${ }^{132}$ Hoe is echter de situatie ingeval de rechtspersoon zijn werknemer uitdrukkelijk geheimhouding heeft opgelegd omtrent de problematiek waar het strafrechtelijk onderzoek betrekking op heeft? De schending van een aldus overeengekomen geheimhoudingsplicht levert een misdrijf op, vervolgbaar op klacht van het bestuur van de onderneming in kwestie. ${ }^{133}$ Moet ook een dergelijke geheimhoudingsplicht voor de getuigplicht wijken, of mag de werknemer die geheimhoudingsplicht laten prevaleren en aldus de verdedigingspositie van de rechtspersoon waarborgen?

Het lijkt mij verdedigbaar dat de werknemer de geheimhouding in acht neemt, ook jegens de verhorende rechter. In dit conflict van rechtsplichten mag hij kiezen voor het naleven van de meest zwaarwegende verplichting en dat is - afgaande op het wettelijk bedreigde strafmaximum - de geheimhoudingsplicht. Beide verplichtingen worden gesanctioneerd met maximaal zes maanden gevangenisstraf, maar de niet-naleving van de getuigplicht wordt bedreigd met een minder hoge geldboete dan de niet-naleving van de geheimhoudingsplicht. Zo bezien zou de keuze van een werknemer om ten faveure van de rechtspersoon te zwijgen gerechtvaardigd zijn. ${ }^{134}$

Voor het geval dit betoog niet zou worden gehonoreerd en de werknemer toch zou moeten getuigen in de zaak tegen de verdachte rechtspersoon, zal hij in voorkomend geval een beroep op het eerder besproken 'nemo tenetur-verschoningsrecht' kunnen doen. In die situatie wordt niet de rechtspersoon beschermd, maar de werknemer zelf. De rechtspersoon kan hooguit op indirecte wijze worden geholpen door een stilzwijgen van de werknemer omtrent potentieel belastende onderwerpen.

Een verdergaande stap in de richting van een 'practical and effective' zwijgrecht voor de verdachte rechtspersoon zou gezet kunnen worden met de erkenning van een afgeleid zwijgrecht voor de werknemers.

\subsection{Werknemers zijn geen gewone getuigen: pleidooi voor een afgeleid zwijgrecht}

Ten opzichte van de rechtspersoon waarvoor zij werkzaam zijn, zijn werknemers geen gewone getuigen en behoren zij dan ook niet als zodanig te worden bejegend. De werknemers maken deel uit van een juridische organisatie die zich in het maatschappelijk verkeer als eenheid manifesteert: de rechtspersoon. Voor zover zij in functie werkzaam zijn ten behoeve van de rechtspersoon, zullen hun gedragingen hebben te gelden als de gedragingen van de rechtspersoon en zullen hun

I32 Zie art. I92 lid I aanhef en onder $\mathrm{I}^{0} \mathrm{Sr}$.

I33 Zie art. $273 \mathrm{Sr}$.

I34 Anders oordeelde Rb. Rotterdam 9 juni 20II, ECLI:NL:RBROT:20II:BQ7633 en ECLI:NL:RBROT: 20Ir:BQ7658, die kennelijk veel gewicht toekende aan het feit dat de geheimhoudingsplicht haar grondslag vond in een contract, terwijl de spreekplicht in kwestie haar grondslag vond in een wettelijk voorschrift. Dat verschil lijkt mij minder relevant, nu artikel $273 \mathrm{Sr}$ de contractuele geheimhouding van een wettelijke bescherming voorziet. Het gaat $\mathrm{m}$.i. om de afweging van twee wettelijk beschermde belangen (rechtsgoederen). 
uitlatingen hebben te gelden als uitlatingen van de rechtspersoon. ${ }^{135}$ Waar het gaat om het vestigen van aansprakelijkheid van de rechtspersoon voor verboden gedragingen (inclusief uitlatingen) wordt dit vrij vanzelfsprekend gevonden. Maar wanneer nu diezelfde werknemers, die als schakelpunt functioneren van gedrag naar aansprakelijkheid, zouden kunnen worden geforceerd om als getuigen zo nodig onder ede een verklaring af te leggen over precies dat gedrag, zou de overheid dus de meest kwetsbare plekken van de organisatorische eenheid mogen opzoeken om daar - kennelijk zonder enige juridische belemmering - het bewijs vandaan te halen. Dat menselijk onderdeel van de organisatorische eenheid waar de vermeende fout is begaan, zou voor de opsporingsambtenaren of voor de vervolgende autoriteiten c.q. de onderzoekende rechter volledig toegankelijk en transparant moeten zijn, althans indien en voor zover de rechtspersoon daartegen geen zwijgrecht in stelling zou kunnen brengen.

In mijn ogen is dat geen evenwichtig systeem. Tegenover het gemak waarmee gedrag (inclusief uitlatingen) van werknemers in materieelrechtelijke zin kan worden toegerekend aan de rechtspersoon, zouden werknemers in formeelrechtelijk opzicht evenzeer moeten worden gezien als het schakelpunt naar de verdachte rechtspersoon: omdat hun verklaringen bewijsrechtelijk voor rekening gebracht zullen worden (en aldus voor rekening komen) van de rechtspersoon, behoren zij - net als de rechtspersoon ten behoeve waarvan zij werkzaam zijn - in staat te worden gesteld het zwijgrecht van de rechtspersoon uit te oefenen. Zo wordt evenwicht gecreëerd, zo kan een 'fair balance' worden aangebracht tussen de verschillende belangen.

De stelling dat een werknemer geen zwijgrecht heeft en (dus) geen cautie hoeft te krijgen omdat hij de rechtspersoon niet vertegenwoordigt, komt er in wezen op neer dat hier wordt vastgehouden aan de aloude orgaantheorie: slechts een daartoe formeel aangewezen bestuurder of gevolmachtigde zou voor de rechtspersoon kunnen spreken, de gewone werknemer zou dat niet kunnen doen. De orgaantheorie is zowel op het vlak van het materiële strafrecht als op dat van het civiele aansprakelijkheidsrecht reeds lang verlaten: niet alleen gedragingen van bestuurders, maar ook gedragingen van werknemers worden de rechtspersoon 'gewoon' toegerekend. ${ }^{136}$ Datzelfde zou naar mijn idee moeten worden aanvaard op het vlak van het strafprocesrecht, waar het gaat om de verklaringen van werknemers. Ook die verklaringen komen voor rekening van de rechtspersoon; zij worden die rechtspersoon inhoudelijk toegerekend. Dit is geen vertegenwoordigingsvraagstuk. Het gaat hier eenvoudigweg om bewijsvergaring waarbij de overheid wil doordringen tot in de sfeer van de rechtspersoon, om vervolgens te kunnen toerekenen. Er is geen reden om aansluiting te zoeken bij de summiere vertegenwoordigingsregeling in het Wetboek van Strafvordering.

Omdat het niet gaat om vertegenwoordiging van de verdachte rechtspersoon, maar om bewijsvergaring ten bezware van die rechtspersoon, behoren de werknemers van die rechtspersoon - als zijnde de aanknopingspunten voor de

I35 Zie HR 2I oktober 2003 (Drijfmest), NJ 2006, 328, m.nt. P.A.M. Mevis en ook reeds HR 6 april I979 (Kleuterschool Babbel), NJ I980, 34, m.nt. C.J.H. Brunner.

I36 Vgl. over 'het afrekenen met de orgaantheorie' ook L. Timmerman, NJV-preadvies over de ontwikkeling van de rechtspersoon in het publiekrecht en privaatrecht, Handelingen NJV 2000-I, Deventer 2000, p. I05-I65, op p. II5-IIg. 
toerekening - het zwijgrecht van de rechtspersoon in stelling te kunnen brengen. Dat zou moeten gelden voor alle werknemers die worden ondervraagd omtrent hun werkzaamheden ten behoeve van de verdachte rechtspersoon. Die benadering is in overeenstemming met het aansprakelijkheidsdenken waarin de rechtspersoon wordt gezien als zelfstandige entiteit die zich in het maatschappelijk verkeer beweegt door gedragingen en uitlatingen van werknemers die hebben te gelden als zijn eigen gedragingen en uitlatingen. Het is ook de meest heldere benadering, omdat vooraf vaak niet duidelijk zal zijn wie van de werknemers binnen de rechtspersoon de meest relevante gedragingen heeft verricht of de meest relevante kennis heeft. Het is niet consequent en ook niet zinvol om werknemers van wie wordt verwacht dat zij op afstand hebben gestaan, anders te bejegenen dan werknemers van wie wordt verwacht dat zij betrokken zijn geweest. ${ }^{137}$ Daarbij is van belang dat de daderschapscriteria voor de rechtspersoon in het Drijfmest-arrest zodanig ruim zijn omschreven dat zelfs ogenschijnlijk onschuldige verklaringen redengevend kunnen zijn, bijvoorbeeld waar het gaat om het schetsen van interne gezagsverhoudingen en de bedrijfscultuur in relatie tot de preventieve zorgplicht.

Betrokkenheid bij de onderzochte feiten in een zaak waarin de rechtspersoon de hoofdverdachte is, is overigens ook niet per definitie richtinggevend voor het aanmerken van een werknemer als getuige of als verdachte. In de zaak betreffende Chemie-Pack werd de werknemer die feitelijk de brand had gesticht die leidde tot de catastrofe (waarbij de onderneming in vlammen opging en de omgeving groot gevaar liep) door het opsporingsteam en het openbaar ministerie bewust niet als verdachte maar als getuige aangemerkt. ${ }^{13^{8}}$ Dat is vermoedelijk gebeurd om het hem gemakkelijker te maken belastend te verklaren over de bedrijfscultuur en de ondernemingsleiding, maar gelet op de gedragingen van deze individuele werknemer was het bepaald opmerkelijk. Het voorbeeld illustreert in elk geval dat het etiketteren van werknemers als getuige of verdachte in voorkomend geval onderdeel kan vormen van een bepaalde opsporingsstrategie. Ook dat pleit voor de aanvaarding van een algemeen geldende rechtswaarborg, waarbij niet nader wordt onderscheiden naar de feitelijke rol van de werknemers.

Het vorenstaande leidt mij tot de conclusie dat het niet alleen redelijk is, maar ook geheel in lijn met het actuele aansprakelijkheidsdenken, rechtens te erkennen dat de werknemers van een verdachte rechtspersoon die worden gehoord als

I37 Vgl. in andere zin nog A.R. Hartmann en M.E. de Meijer, 'De personele werkingssfeer van het zwijgrecht en de cautieverplichting bij de verdachte rechtspersoon', NJB I996, p. I768-I773 en 'Naschrift', NJB I997, p. 343-344, alsmede A.N. van Kesteloo, De rechtspersoon in het strafrecht, Deventer 2013 , p. I26. Hun genuanceerde opvatting dat alleen de werknemers wier gedrag of kennis bruikbaar is voor het vestigen van de strafrechtelijke aansprakelijkheid van de rechtspersoon een beroep zouden kunnen doen op het afgeleide zwijgrecht, lijkt mij in de praktijk niet goed hanteerbaar. Vóór het verhoor zal immers reeds duidelijk moeten zijn of het zwijgrecht kan worden ingeroepen en op dat moment zal logischerwijs nog niet kunnen worden beoordeeld welke verklaring van welke werknemer bruikbaar bewijs bevat voor de zaak tegen de rechtspersoon. Zie ook hierna, onderdeel 4.8 .

I38 Zie Rb. Breda 22 december 20I2, ECLI:NL:RBBRE:20I2:BY70oo. De werknemer in kwestie had, voorafgaand aan zijn verhoor als getuige, namens de officier van justitie de onvoorwaardelijke toezegging gekregen dat hij in het strafrechtelijk onderzoek nooit meer als verdachte zou worden aangemerkt, ongeacht zijn mogelijke uitspraken. 
getuige, zich (in afgeleide zin) op het zwijgrecht van hun rechtspersoon kunnen beroepen. In het verlengde daarvan behoren zij dan ook de cautie te krijgen, teneinde te voorkomen dat zij ongewild meewerken aan de veroordeling van de organisatie waarvan zij zelf deel uitmaken. ${ }^{\mathrm{I} 39}$

\subsection{Leidt aanvaarding van een afgeleid zwijgrecht tot bewijsmoeilijkheden?}

Het zojuist gehouden betoog lijkt wellicht vergaand, maar aanvaarding daarvan zal naar mijn verwachting in de praktijk geen aardverschuivingen teweegbrengen. Het zwijgrecht is nu eenmaal een recht dat veel mensen niet benutten. In de rechtstreekse confrontatie met de verhorend ambtenaar voelen velen zich geroepen toch antwoord te geven op de gestelde vragen: ofwel als gevolg van de psychische druk die een verhoor met zich meebrengt ${ }^{140}$, ofwel ingegeven door de gedachte dat men toch niets te verbergen heeft en door de vrees dat zwijgen een verkeerde indruk zou geven, vaak ook door een combinatie van dergelijke factoren. Men kan dat een ietwat naïeve en weinig principiële benadering noemen, maar zij leidt er wel toe dat de meeste verdachten 'gewoon' meewerken aan verhoren en verklaringen afleggen. ${ }^{\text {I4I }}$ Dit zal voor werknemers die slechts als getuige worden benaderd uiteraard niet anders zijn en dit zal ook niet wezenlijk veranderen wanneer hen wordt gewezen op een zwijgrecht. Uiteindelijk zijn zij ook naar huidig recht niet verplicht om mee te werken aan verhoren van opsporingsambtenaren, terwijl zij dat vaak toch doen..$^{\text {I42 }}$ Op grond van deze ervaringsgegevens is het niet aannemelijk dat de erkenning van een afgeleid zwijgrecht met bijbehorende cautie ertoe zal leiden dat werknemers daadwerkelijk categorisch zullen gaan zwijgen. Maar: die erkenning is wel van fundamenteel belang voor de mogelijkheden van de verdachte rechtspersoon om zijn zwijgrecht überhaupt te kúnnen effectueren.

Dat die erkenning tot grote bewijsmoeilijkheden zou leiden, zoals wel is gesteld, ${ }^{\mathrm{I}} 43$ lijkt mij een ongegronde vrees, ${ }^{\mathrm{I} 44}$ niet alleen omdat de rechtspersoon zijn werknemers het spreken uiteindelijk niet onmogelijk kan maken en per saldo afhankelijk is van hun loyaliteit en standvastigheid, maar ook omdat de vervolgende autoriteit in de regel een compleet arsenaal aan alternatieve onderzoeksbevoegdheden kan

I39 Het gaat hier dus niet om een eigen zwijgrecht, maar om een van de verdachte rechtspersoon afgeleid zwijgrecht waarop de getuige zich moet kunnen beroepen. Vgl. in dit verband reeds $\mathrm{H}$. de Doelder, 'De onderneming en de strafvordering', Account Dossier I992, nr 7, p. 22-3I, op p. 24, waar hij stelt dat het geven van de cautie aan de werknemers een einde kan maken aan de ongerijmde situatie dat het bewijs tegen de onderneming door eigen personeel wordt geleverd.

I40 Zoals expliciet erkend in HR I oktober I985, NJ I986, 405, en HR I oktober I985, NJ I986, 406, beide m.nt. Th.W. van Veen.

I4I Voor de meeste mensen is het in een verhoorsituatie gemakkelijker om te spreken dan te zwijgen, aldus ook G.J.M. Corstens, Het Nederlands strafprocesrecht, $8^{\mathrm{e}}$ druk, bewerkt door M.J. Borgers, Deventer 20I4, p. 305.

I42 Weliswaar kan de werkgever dat trachten tegen te gaan door de werknemers tot geheimhouding te verplichten (zie onderdeel 4.5), maar ook dan heeft hij nog geen volledige controle. Een werknemer die ten overstaan van een verhorend rechter zijn getuigplicht laat prevaleren boven zijn geheimhoudingsplicht, zal bovendien rechtens vermoedelijk geen verwijt kunnen worden gemaakt.

I43 Zie in dat verband vooral R.A. Torringa, a.w., p. I35.

I44 Zie ook reeds D.R. Doorenbos, 'Het zwijgrecht van de rechtspersoon', Tijdschrift voor Sanctierecht \& Compliance 2013, $\mathrm{nr}$ 5/6, p. I75-181, op p. 177-178, met nadere bronvermelding. 
inzetten die de waarheidsvinding kunnen dienen. Dat varieert van de toezichthoudende bevoegdheden uit de Awb, tot de onderzoeksbevoegdheden uit de WED, tot de algemene opsporingsbevoegdheden uit het Wetboek van Strafvordering, al of niet aangevuld met bevoegdheden uit de bijzondere wetten. De meeste rechtspersonen zijn extern gericht, hebben zichtbare vestigingen en uitgebreide administraties, archiefruimtes en digitale gegevensopslag. Vaak opereren zij op grond van een vergunning en moeten zij periodiek en incidenteel informatie verstrekken aan hun toezichthouders. Een anoniem bestaan is voor een rechtspersoon niet weggelegd en ondernemingsactiviteiten uitvoeren zonder dat dit zichtbaar is en sporen achterlaat, praktisch ondenkbaar. De angst voor bewijsmoeilijkheden indien de rechtspersoon zijn zwijgrecht in de opsporingsfase effectief kan uitoefenen, is daarom niet reëel te achten. Enig ongemak is misschien niet uit te sluiten, maar dat wordt gecompenseerd door de alternatieve mogelijkheden voor bewijsgaring in combinatie met de inmiddels zeer ruime mogelijkheden voor aansprakelijkstelling van de rechtspersoon. ${ }^{145}$ Tegenover die royale mogelijkheden voor de strafrechtelijke autoriteiten om hun zaak tegen de rechtspersoon 'rond' te krijgen, zou een wat royaler omgang met het zwijgrecht van de rechtspersoon voor een beter evenwicht zorgen.

\subsection{Enige discussie}

De opvatting dat de werknemers van een verdachte rechtspersoon zich zouden moeten kunnen beroepen op het (van de rechtspersoon afgeleide) zwijgrecht, is eerder naar voren gebracht ${ }^{\mathrm{I} 46}$, maar wordt niet algemeen gedeeld. De rechtspraak hieromtrent is uiterst schaars en tot nu toe afwijzend. ${ }^{147}$ In de literatuur lopen de meningen uiteen. ${ }^{\mathrm{I} 8}$

Jörg heeft in dit verband drie concrete bezwaren geuit. ${ }^{\mathrm{I} 9}$ In de eerste plaats ligt het volgens hem weinig voor de hand om een zwijgrecht te garanderen aan personen die in het geheel niet als normadressaat in beeld komen. In de tweede plaats kan van opsporingsambtenaren moeilijk worden gevergd dat zij vooraf onderscheid maken tussen werknemers die wel en werknemers die niet zullen bijdragen aan de aansprakelijkheidsconstructie ten laste van de rechtspersoon. En ten slotte

I45 Ter illustratie zij in dat verband verwezen naar B.F. Keulen e.a., Daderschap en deelneming doorgelicht, Zutphen 2010, p. 106-I07, waar een advocaat wordt aangehaald die stelt dat de Drijfmest-criteria in de praktijk een strafrechtelijke risicoaansprakelijkheid voor de rechtspersoon hebben gecreëerd.

I46 Zie m.n. A.R. Hartmann en M.E. de Meijer, 'De personele werkingssfeer van het zwijgrecht en de cautieverplichting bij de verdachte rechtspersoon', NJB I996, p. I768-I773 en 'Naschrift', NJB I997, p. 343-344

I47 Zie Hof 's-Gravenhage ig juni 1996 (inzake Van der Valk, niet gepubliceerd), aangehaald door Hartmann en De Meijer, a.w., p. I770-I77I, alsmede Rb. Zeeland-West-Brabant 24 maart 20I4, ECLI:NL:RBZWB:20I4:I9II (inzake Dow Benelux BV).

I48 Zie o.a. E. Myjer, 'Rechtspersoonlijk recht op een behoorlijke strafprocedure?', in: M. van Kraaij en A. van Veen (red.), Onderneming en Strafrecht, Nijmegen I997, p. 2I-32, op p. 29, met nadere literatuuropgave. Myjer toonde zich daar nog geen voorstander van het afgeleide zwijgrecht. Vgl. meer recent ook de discussie tussen M. Bakker en J. Mooijen, 'Het zwijgen van de onderneming: een advocaat en officier van justitie spreken', Tijdschrift Onderneming \& Strafrecht in Praktijk 2014, nr 5/6, p. IO-I5.

I49 Zie N. Jörg in Melai c.s., Wetboek van Strafvordering (losbl.), aant. I5 op art. 29 Sv, Suppl. I64 (december 2007). 
zou het strafprocessuele begrip vertegenwoordiger als zijnde degene die bindend namens de rechtspersoon mag spreken, materieel wel erg opgerekt worden, aldus deze auteur.

Het eerste bezwaar lijkt eraan voorbij te zien dat het hier bedoelde zwijgrecht er niet toe dient de werknemer zelf te beschermen, maar dat het gaat om de bescherming van de rechtspersoon: de verdachte normadressaat. Het gaat om een afgeleid zwijgrecht. Het zwijgrecht komt primair toe aan de verdachte rechtspersoon en kan in stelling worden gebracht ten behoeve van die rechtspersoon (de normadressaat) voor het geval de werknemer wordt gehoord als getuige. Indien de werknemer zelf verdachte is, heeft hij uiteraard al een eigen zwijgrecht. Overigens acht ik het bezwaar evenmin gegrond indien het er wèl om zou gaan dat de werknemer zelf enig risico zou moeten kunnen lopen en dus bescherming zou behoeven. Het feit dat uitsluitend de rechtspersoon normadressaat kan zijn, laat immers onverlet dat de werknemers dan zouden kunnen worden beschouwd als deelnemers (medeplegers, medeplichtigen) of feitelijk leidinggevenden.

Het tweede bezwaar deel ik, vandaar dat ik (anders dan Hartmann en De Meijer) van oordeel ben dat bij het horen van werknemers geen onderscheid zou moeten worden gemaakt naar gelang hun vermeende betrokkenheid of kennis. Zoals hiervoor reeds werd toegelicht, zouden dus inderdaad alle werknemers die in de zaak van de verdachte rechtspersoon als getuige worden benaderd, het zwijgrecht van die rechtspersoon in stelling moeten kunnen brengen.

Het derde bezwaar gaat er kennelijk van uit dat de werknemer die - gehoord als getuige - het zwijgrecht van de verdachte rechtspersoon in stelling brengt, zich daarmee opwerpt als vertegenwoordiger. Dat is niet het geval. De werknemer is en blijft getuige. Indien hij zou verklaren, zou dat de rechtspersoon niet binden - omdat hij niet de vertegenwoordiger is - maar zou dat de rechtspersoon wel kunnen worden toegerekend. Het begrip vertegenwoordiger blijft op zichzelf zoals het is en wordt dus niet opgerekt.

\subsection{Vergelijking met het afgeleide verschoningsrecht}

Zoals de werknemers van een verschoningsgerechtigde beroepsbeoefenaar zich in afgeleide zin kunnen beroepen op diens verschoningsrecht, zo zouden werknemers van een verdachte rechtspersoon zich dan in afgeleide zin kunnen beroepen op het zwijgrecht van hun werkgever. De grondslag van deze erkenning wordt gevonden in het besef dat er van het bedoelde recht niets (of in elk geval: te weinig) overblijft indien politie en justitie met voorbijgaan aan de rechthebbende zijn ondergeschikten kunnen uithoren.

De hier voorgestelde analogie met het professionele verschoningsrecht ligt in zekere zin voor de hand. De grondslag van het professionele verschoningsrecht moet volgens de Hoge Raad worden gezocht in een in Nederland geldend algemeen rechtsbeginsel dat meebrengt dat bij bepaalde vertrouwenspersonen - waaronder de advocaat in strafzaken - het maatschappelijk belang dat de waarheid in rechte aan het licht komt, moet wijken voor het maatschappelijk belang dat een ieder zich vrijelijk en zonder vrees voor openbaarmaking van het besprokene om bijstand en 
advies tot hen moet kunnen wenden. ${ }^{150}$ Hierin ligt besloten dat de informatie die een verdachte deelt met zijn advocaat, niet aan derden hoeft te worden medegedeeld, zelfs niet aan de rechter en ongeacht de vraag hoe belastend die informatie zou zijn. Het verschoningsrecht waarborgt de geheimhouding daarvan en fungeert daarmee in zekere zin als het verlengstuk van het zwijgrecht van de verdachte. Aan het zwijgrecht komt rechtens niet minder gewicht toe dan aan het verschoningsrecht. Beide rechten waarborgen de vertrouwelijkheid van informatie die mogelijk cruciaal is voor de waarheidsvinding, maar die desondanks door de verdachte en zijn raadsman geheim mag worden gehouden.

De advocaat mag zich verschonen en het is in confesso dat zijn werknemers - de receptionist, de secretaresse, de medewerkers - zich kunnen beroepen op zijn verschoningsrecht. ${ }^{\mathrm{III}}$ De verdachte rechtspersoon mag zwijgen, maar het is allerminst zeker dat zijn werknemers - de receptionist, de secretaresse, de medewerkers zich kunnen beroepen op zijn zwijgrecht. Het verschoningsrecht is 'practical and effective' maar het zwijgrecht is mogelijk slechts 'theoretical and illusory' tenzij de rechter de voorgestane analogie volgt en voor de werknemers van de verdachte rechtspersoon een afgeleid zwijgrecht erkent.

Een wetswijziging lijkt daarvoor niet nodig. Ook het afgeleide verschoningsrecht komt als zodanig in de wet niet voor en heeft zich toch ontwikkeld tot een behoorlijk stevige rechtswaarborg. ${ }^{152}$

\section{Io Verklaringsvrijheid in het licht van artikel $285 \mathrm{a} \mathrm{Sr}$}

Een verdachte moet in vrijheid kunnen verklaren en is niet tot antwoorden verplicht. Hij moet zelf kunnen bepalen of en in hoeverre hij op enig moment in het strafrechtelijk onderzoek een verklaring aflegt. Indien hij er niet voor kiest te zwijgen, moet hij uiteraard ook zelf kunnen bepalen wat de inhoud van zijn verklaring is en op welke punten die verklaring betrekking zal hebben. De verklaringsvrijheid van de verdachte vindt haar erkenning in artikel $29 \mathrm{~Sv}^{153}$, waarin het pressieverbod, het zwijgrecht en de cautieplicht zijn neergelegd.

Terwijl het uitgangspunt wellicht vanzelfsprekend is, is het nog lastig om te bepalen hoe een verdachte rechtspersoon gebruik kan maken van zijn verklaringsvrijheid. Het is hem uiteraard toegestaan zijn vertegenwoordiger daarin te instrueren,

I50 Zie o.a. HR I maart I985 (Notaris Maas), NJ I986, I73, m.nt. W.L. Haardt (onder NJ I986, I76).

I5I Zie o.a. de CAG (Jörg) bij HR I2 oktober 20I0, NJ 20II, 537, m.nt. J.M. Reijntjes, onderdeel 86: 'Voorts wordt algemeen aanvaard dat de plicht tot geheimhouding van de advocaat niet alleen geldt voor hemzelf, doch ook voor het te zijnen kantore werkzame personeel, en dat aan de desbetreffende personeelsleden op grond daarvan een afgeleid verschoningsrecht toekomt. Deze uitbreiding is op praktische gronden geboden, omdat anders het recht en de plicht van de advocaat tot geheimhouding voor een belangrijk gedeelte illusoir zouden worden, gelet op de voor de advocaat bestaande noodzaak bedoelde personeelsleden bij zijn werkzaamheden te betrekken.'

I52 Overigens kan ook een rechtspersoon zich onder omstandigheden op een afgeleid verschoningsrecht beroepen, zoals een stichting die werkzaam is op het terrein van de gezondheidszorg zich kan verzetten tegen de inbeslagneming van informatie met een beroep op het verschoningsrecht van een arts die voor haar werkzaam is. Zie in dat verband HR 29 juni 2004, NJ 2005, 273, m.nt. G. Knigge.

I53 Zie recent nog HR 4 maart 20I4, NJ 20I4, 474, m.nt. J.M. Reijntjes, waarin de Hoge Raad uitdrukkelijk spreekt over 'de aan art. 29 Sv ten grondslag liggende verklaringsvrijheid van de verdachte'. 
maar is het hem ook toegestaan om de woordvoering vanuit de rechtspersoon te coördineren en te concentreren bij één of enkele personen? Mag de rechtspersoon zijn werknemers instrueren waarover zij wel of niet zullen mogen verklaren?

Naar mijn mening moeten deze vragen bevestigend worden beantwoord. De rechtspersoon kan niet anders verklaren dan door middel van de natuurlijke personen die zich binnen zijn organisatie bevinden en juridisch aan hem verbonden zijn. De rechtspersoon wordt geacht deze natuurlijke personen te kunnen sturen in hun gedrag, reden waarom hij daarop strafrechtelijk zal worden 'afgerekend' indien hij daarin tekortschiet. Indien de rechtspersoon niet de zorg betracht die in redelijkheid van hem kan worden gevergd met het oog op de voorkoming van verboden gedragingen van zijn werknemers, zullen die gedragingen hem in de regel worden toegerekend. ${ }^{154}$ Deze benadering is niet onredelijk. Maar omgekeerd lijkt dan evenmin onredelijk wanneer wordt aanvaard dat de rechtspersoon niet alleen zijn handelen, maar ook zijn uitingen kan (en moet kunnen) beheersen door zijn werknemers te instrueren over de wijze waarop zij zich jegens derden zoals opsporingsambtenaren zullen mogen opstellen. Aldus wordt een 'fair balance' aangebracht tussen de bewijslast ter zake van de strafrechtelijke aansprakelijkheid en de verdedigingspositie van de verdachte rechtspersoon.

In de praktijk plegen opsporingsambtenaren zich intussen niet te storen aan het verzoek van de verdachte rechtspersoon om verhoren van zijn werknemers niet buiten de rechtspersoon om te organiseren. De wens van een verdachte rechtspersoon zijn woordvoering te coördineren, waarbij hij bijvoorbeeld ook in staat zou moeten zijn te bepalen welke werknemer in de beste positie is om over een bepaald onderwerp van de bedrijfsvoering een verklaring af te leggen (en welke werknemer niet), wordt zelden of nooit gerespecteerd. Veeleer hebben opsporingsambtenaren de neiging de werknemers en de verdachte rechtspersoon uit elkaar te spelen, door werknemers voor te houden dat hun belang een ander is dan dat van de rechtspersoon $^{155}$ en door niet te accepteren dat werknemers zich laten vergezellen door de raadsman van de rechtspersoon. Bij dat laatste wordt dan gewezen op een door het opsporingsteam onwenselijk geachte 'belangenverstrengeling' - een kwalificatie die ironisch genoeg precies aanduidt dat en waarom de belangen van de werknemers en de verdachte rechtspersoon in dezen doorgaans uitstekend door één raadsman of advocatenkantoor kunnen worden behartigd: die belangen lopen immers vaak volledig parallel en zijn nauw met elkaar verbonden.

Het instrueren van werknemers omtrent hetgeen zij wel of niet zouden mogen verklaren, zou de rechtspersoon wel eens in conflict kunnen brengen met artikel 285a lid I Sr, luidende:

I54 Zie HR 2I oktober 2003 (Drijfmest), NJ 2006, 328, m.nt. P.A.M. Mevis.

I55 Het uitoefenen van deze 'zachte drang' richting werknemer is overigens niet onbedenkelijk, gelet op de in art. 7:6II BW neergelegde verplichting van een werknemer om zich als een goed werknemer te gedragen, hetgeen meebrengt dat hij in beginsel tegenover zijn werkgever is gehouden tot discretie en loyaliteit. Dit geldt ook indien de werknemer van mening is dat binnen de organisatie sprake is van een misstand die in het algemeen belang dient te worden bestreden. Zie o.a. HR 26 oktober 2012, ECLI:NL:HR:2012:BW9244. 
'Hij die opzettelijk mondeling, door gebaren, bij geschrift of afbeelding zich jegens een persoon uit, kennelijk om diens vrijheid om naar waarheid of geweten ten overstaan van een rechter of ambtenaar een verklaring af te leggen te beïnvloeden, terwijl hij weet of ernstige reden heeft te vermoeden dat die verklaring zal worden afgelegd, wordt gestraft met gevangenisstraf van ten hoogste vier jaren of geldboete van de vierde categorie.'

Deze strafbaarstelling werd geïntroduceerd bij de Wet getuigenbescherming. ${ }^{156} \mathrm{De}$ Hoge Raad heeft geoordeeld dat de reikwijdte van artikel 285a Sr niet beperkt is tot gevallen waarin sprake is van bedreiging of intimidatie van de getuige ${ }^{157}$, ofschoon daar in de wetsgeschiedenis duidelijk wel de nadruk $\operatorname{lag}^{158}$. De tekst is zodanig ruim dat ook de rechtspersoon die zijn werknemers zou (laten) instrueren om in het kader van een strafrechtelijk onderzoek over bepaalde aangelegenheden te zwijgen, dan wel daarover een intern afgestemde verklaring af te leggen, in de termen van deze delictsomschrijving zou kunnen vallen. ${ }^{159}$ Hetzelfde zou dan gelden voor de advocaat die de rechtspersoon hierin heeft geadviseerd.

Deze strikte uitleg zou de verdedigingspositie van de rechtspersoon praktisch onmogelijk maken. Noodzakelijkerwijs moet de verdachte rechtspersoon zijn verklaringsvrijheid in handen leggen van zijn werknemers. Indien de verdachte rechtspersoon dan niet meer vrijelijk zou mogen bepalen of, hoe en in hoeverre hij via deze werknemers binnen het strafrechtelijk onderzoek zal verklaren, is er voor hem praktisch gesproken geen verklaringsvrijheid. Een redelijke wetsuitleg zal derhalve moeten meebrengen dat instructies van een verdachte rechtspersoon aan zijn werknemers die ertoe strekken diens verklaringsvrijheid in het opsporingsonderzoek te gebruiken in het belang van zijn verdediging, niet worden getroffen door artikel 285 a Sr.

Ook de werkgever die zijn werknemer verplicht tot geheimhouding van bijzonderheden aangaande de onderneming en haar bedrijfsactiviteiten, behoort daartoe de vrijheid te hebben. Het enkele feit dat deze geheimhouding de werknemer kan belemmeren in zijn vrijheid om in een verhoor van opsporingsambtenaren - rechtens onverplicht - de hem gestelde vragen te beantwoorden, kan niet leiden tot de gevolgtrekking dat de werkgever strafbaar heeft gehandeld. De betrekkelijk summiere wetsgeschiedenis van artikel 285 a Sr bevat geen aanwijzingen dat met deze strafbepaling zou zijn beoogd de vrijheid van de werkgever in dezen in te perken. Dat zou ook moeilijk te rijmen zijn met artikel $273 \mathrm{Sr}$, de strafbepaling die er juist toe strekt te bevorderen dat (ex-)werknemers de hun opgelegde geheimhouding ook daadwerkelijk in acht zullen nemen.

I56 Wet van II november I993, Stb. 603, in werking getreden op I februari 1994.

I57 Zie o.a. HR I4 september 2010, NJ 2010, 499.

I58 Zie Kamerstukken II 199i/92, 22 483, nr 3, p. 39.

I59 Vgl. daarover ook B.G.H. de Ruyter, 'Wiens brood men eet, diens woord men spreekt ... of zwijgt?, Het dilemma van de werknemer', NJB 2008, p. 622-630. Vgl. voorts de CAG (Machielse) bij HR 20 mei 2008, NJ 2008, 302, onder punt 3.17, waar hij stelt: '[D] e tekst van art. 285a Sr brengt niet mee dat de uitlatingen een bedreigend of vreesaanjagend intimiderend karakter moeten hebben. Wel zal er beïnvloeding moeten zijn; enige vorm van ontmoediging om een belastende verklaring af te leggen. Daarmee kan worden gelijkgesteld de aanmoediging om een ontlastende verklaring af te leggen.' 
Overigens is ook in andere opzichten noodzakelijk te achten dat de reikwijdte van artikel 285 a Sr interpretatiegewijs wordt ingeperkt. Letterlijk genomen bestempelt deze wettekst namelijk reeds de normale beroepsuitoefening van de advocaat tot misdrijf. Elke advocaat zal immers in de voorbereiding op een verhoor zijn cliënt beïnvloeden in diens verklaringsvrijheid, hem erop wijzen dat het verstandig is op bepaalde onderdelen terughoudend te zijn teneinde zichzelf of een ander niet te belasten respectievelijk hem aanmoedigen op bepaalde onderdelen juist krachtig in ontlastende zin te verklaren. Dat behoort tot de kerntaken van de advocaat en wanneer dat strafbaar zou zijn, zoals de wettekst suggereert ${ }^{160}$, wordt de balie bevolkt door gewoontemisdadigers. ${ }^{16 \mathrm{I}}$

\section{II Het binnentreden van bedrijfsgebouwen en artikel 8 EVRM}

In artikel 8 EVRM worden zogenoemde 'privacyrechten' gewaarborgd. Het gaat dan om het recht op respect voor het privéleven, het familie- en gezinsleven, de woning en de correspondentie. Daargelaten de moeder- en dochterrelaties in concernverband, zal duidelijk zijn dat een rechtspersoon geen familie- of gezinsleven heeft. Minder duidelijk is of en in hoeverre de rechtspersoon een privéleven kan hebben: het EHRM heeft zich daar nog niet nader over uitgesproken. ${ }^{162}$ Maar wel staat reeds vast dat de rechtspersoon aanspraak kan maken op de beide andere privacyrechten: respect voor zijn woning en respect voor zijn correspondentie. In het navolgende zal de aandacht vooral uitgaan naar het eerstgenoemde recht, omdat daarover in de context van de Nederlandse wetgeving nog steeds een belangrijke discussie speelt.

Wanneer de woorden 'private life' en 'home' zo worden uitgelegd dat zij zich mede uitstrekken tot bepaalde 'professional or business activities or premises', is dat in overeenstemming met de strekking van artikel 8 EVRM, zo oordeelde het EHRM reeds in $1992 .{ }^{163}$ Deze verdragsbepaling strekt namelijk tot bescherming van het individu tegen 'arbitrary interference by the public authorities' ${ }^{164}$ In deze benadering is het nog maar een kleine stap naar het beschermen van rechtspersonen tegen dergelijke inbreuken.

Aanvankelijk legde het EHRM vrij sterk de nadruk op het gegeven dat privé en zakelijk functioneren in de praktijk vaak lastig te (onder)scheiden zijn. Daarom zou

I6o Waarbij opmerking verdient dat de wettekst spreekt van 'een persoon' en daarmee dus geen onderscheid maakt tussen getuigen en verdachten.

I6I Omgekeerd zou op grond van de wettekst met hetzelfde gemak kunnen worden betoogd dat het misdrijf van artikel 285 a Sr bij uitstek wordt gepleegd door opsporingsambtenaren, nu die er praktisch altijd op uit zijn de door hen verhoorde personen te beïnvloeden in hun verklaringsvrijheid.

I62 Zie in dat verband nog EHRM 28 juni 2007 (Association for European Integration and Human Rights en Ekimdzhiev), Appl. nr 62540/00, par. 6o, waarin werd overwogen: 'While it may be open to doubt whether, being such a person [a legal person, DD], it can have a "private life" within the meaning of that provision, it can be said that its mail and other communications, which are in issue in the present case, are covered by the notion of "correspondence" which applies equally to communications originating from private and business premises.'

I63 Zie EHRM I6 december I992 (Niemietz), NJ I993, 400, m.nt. E.J. Dommering (par. 3I).

I64 Zie dienovereenkomstig o.a. HR 3 oktober I995, NJ I996, 219, m.nt. G. Knigge, in r.o. 5.4: 'Art. 8 EVRM biedt bescherming tegen willekeurige inbreuken door enig openbaar gezag op de in het eerste lid bedoelde rechten.' 
een enge interpretatie van de aangehaalde woorden in artikel 8 EVRM niet op haar plaats zijn. ${ }^{165}$

In 2002 volgde echter een uitspraak waarin een meer volledige erkenning ligt besloten van het recht van rechtspersonen op respect voor hun privésfeer. In dit belangrijke arrest - de zaak Société Colas Est ${ }^{166}$ - werd overwogen:

'The Court reiterates that the Convention is a living instrument which must be interpreted in the light of present-day conditions (...). Building on its dynamic interpretation of the Convention, the Court considers that the time has come to hold that in certain circumstances the rights guaranteed by Article 8 of the Convention may be construed as including the right to respect for a company's registered office, branches or other business premises (...). ${ }^{167}$

In de overwegingen van het EHRM komt tot uitdrukking dat het hier gaat om het zelfstandig recht van de rechtspersoon op respect voor zijn 'woning'. Dit recht van de rechtspersoon valt niet samen met de rechten van zijn werknemers en het zijn dan ook niet primair de rechten van de werknemers die hier worden beschermd, ook al profiteren zij tot op zekere hoogte mee. Om in aanmerking te komen voor rechtsbescherming tegen ongerechtvaardigde inbreuken op het recht op respect voor zijn woning, hoeft de rechtspersoon in voorkomend geval dus niet aannemelijk te maken dat (ook) de rechten van zijn werknemers zijn geschonden. ${ }^{168}$

De meer volledige erkenning dat ook rechtspersonen rechten kunnen ontlenen aan artikel 8 lid I EVRM betekent niet dat de rechtsbescherming van de rechtspersoon tegen willekeurige inbreuken op hetzelfde niveau ligt als dat van de natuurlijke persoon. In de zaak-Niemietz overwoog het EHRM al dat de mogelijkheden voor de overheid om op geoorloofde wijze inbreuk te maken op de hier bedoelde rechten wel eens verder zouden kunnen gaan in de zakelijke sfeer (waar de meeste rechtspersonen zich bevinden) dan elders. In latere rechtspraak is dat bevestigd: wanneer het optreden was gericht op een rechtspersoon, kan volgens het EHRM bij de toetsing in de context van artikel 8 EVRM 'a wider margin of appreciation' in acht worden genomen dan wanneer het optreden betrekking zou hebben gehad op een natuurlijke persoon. ${ }^{169}$

I65 Zie EHRM I6 december 1992 (Niemietz), NJ I993, 400, m.nt. E.J. Dommering, waarin het ging om een vrije beroepsbeoefenaar en ook reeds EHRM 30 maart Ig89 (Chappell), NJ I99I, 522, m.nt. E.J. Dommering, waarin het ging om een bedrijf aan huis.

I66 Zie EHRM I6 april 2002 (Société Colas Est e.a.), AB 2002, 277, m.nt. O.J.D.M.L. Jansen en NJ 2003, 452, m.nt. E.J. Dommering. Het arrest wordt ook uitvoerig besproken door M. Emberland, The Human Rights of Companies, Oxford 2008, die er de kwalificatie 'Avant-Garde Jurisprudence' aan geeft en het arrest ziet als een 'landmark case'.

I67 Zie EHRM I6 april 2002 (Société Colas Est e.a.), par. 4I.

I68 Vgl. EHRM I4 maart 20I3 (Bernh Larsen Holding AS), Computerrecht 20I3, II9, m.nt. M.M. Groothuis (par. 90), alsmede EHRM 2 oktober 2014 (Delta Pekárny AS), AB 2015, 29, m.nt. T. Barkhuysen en M.L. van Emmerik (par. 65). Vgl. ook EHRM 28 juni 2007 (Association for European Integration and Human Rights en Ekimdzhiev), Appl. nr 62540/00, in par. 6r: '(...) the Article 8 rights in issue in the present case are those of the applicant association, not of its members.'

I69 Zie reeds EHRM I6 april 2002 (Société Colas Est), in par. 49. Zie intussen wat explicieter ook EHRM I4 maart 2013 (Bernh Larsen Holding AS), in par. I59 en EHRM 2 oktober 2014 (Delta Pekárny AS), in par. 82. Zie voor een toepassing van deze nuance bijvoorbeeld Rb. Maastricht 24 januari 2007, ECLI:NL:RBMAA:2007:AZ83II. 


\subsection{Een vergaande inbreuk}

Indien opsporingsambtenaren een bedrijfsterrein betreden of een bedrijfsgebouw binnengaan zonder dat zij daarvoor toestemming hebben gevraagd of gekregen van de rechtspersoon wiens 'business premises' het betreft, zal dat in beginsel reeds zijn aan te merken als een inbreuk op de rechten die de rechtspersoon ontleent aan artikel 8 EVRM. ${ }^{170}$

Uitgangspunt moet zijn dat een dergelijke inbreuk niet is toegestaan, omdat deze verdragsbepaling bescherming biedt tegen inmenging van enig openbaar gezag in de uitoefening van de hier bedoelde rechten. Zulke inmenging is slechts toegestaan voor zover bij de wet voorzien en tevens - zoals het tweede lid van artikel 8 EVRM het formuleert - in een democratische samenleving noodzakelijk in het belang van de nationale veiligheid, de openbare veiligheid of het economische welzijn van het land, het voorkomen van wanordelijkheden en strafbare feiten, de bescherming van de gezondheid of de goede zeden of voor de bescherming van de rechten en vrijheden van anderen.

Het betreden van plaatsen zoals bedrijfsterreinen en bedrijfsgebouwen gaat meestal gepaard met de uitoefening van andere onderzoeksbevoegdheden, zoals het inzien van de bedrijfsadministratie, het onderzoeken van zaken, het nemen van monsters, de inbeslagneming van voorwerpen c.q. het vorderen van de uitlevering daarvan en het horen van de aanwezige personen. Het belang van de betredingsbevoegdheid is dan ook groot: indien de opsporingsambtenaren zich toegang hebben verschaft en zijn doorgedrongen tot de fysieke organisatie van de rechtspersoon, kunnen zij op eenvoudige wijze tal van andere onderzoeksmogelijkheden benutten. Een doorzoeking kan dan veelal achterwege blijven. ${ }^{171}$

Vanuit het perspectief van de betrokken rechtspersoon is voorstelbaar dat deze de opsporingsambtenaren liever buiten de poort houdt. Ook de rechtspersoon die in strafrechtelijk opzicht onschuldig is, kan het toch bepaald onaangenaam en onwenselijk vinden wanneer opsporingsambtenaren zonder toestemming de bedrijfsgebouwen betreden en - eenmaal binnen - de administratie inzien en kopiëren, zaken onderzoeken, voorwerpen in beslag nemen en werknemers ondervragen. Ook die rechtspersoon zal dus graag zien dat de toepassing van de belangrijke basisbevoegdheid tot binnentreden aan strikte voorwaarden wordt gebonden, opdat hij gevrijwaard kan blijven van willekeurige inbreuken op zijn 'huisrecht'. Maar hoe strikt zijn die voorwaarden in Nederland eigenlijk?

I70 Terzijde zij opgemerkt dat ingeval wel toestemming wordt verkregen maar aannemelijk is dat die is gegeven onder de dreiging van verdergaande dwang, het overheidsoptreden nog steeds zal zijn aan te merken als een inbreuk op de rechten van artikel 8 EVRM. Vgl. o.a. EHRM I4 september 2010 (Sanoma Uitgevers BV), in par. 68-70, alsmede EHRM I8 april 2013 (Saint-Paul Luxembourg SA), in par. 38 .

I7I Vgl. ook de recente uitbreiding van de wettelijke bevoegdheid van de Autoriteit Consument en Markt tot het binnentreden van woningen zonder toestemming van de bewoner (art. I2c Instellingswet ACM). Omdat de toezichthoudende ambtenaar - eenmaal binnen in de woning - reeds zoveel onderzoeksmogelijkheden heeft, zal hij een doorzoekingsbevoegdheid niet nodig hebben, aldus (vrij vertaald) de toelichting van de regering op deze wetswijziging; zie Kamerstukken II $2012 / \mathrm{I}_{3}, 33622, \mathrm{nr} 3, \mathrm{p} .8$. 


\section{I3 Wettelijke voorschriften inzake het betreden van bedrijfsruimten}

\section{Wetboek van Strafuordering}

In het systeem van het Wetboek van Strafvordering wordt de bevoegdheid tot het betreden van plaatsen steeds gekoppeld aan andere opsporingsbevoegdheden. Zo mogen plaatsen worden betreden om te kunnen overgaan tot aanhouding, inbeslagneming, doorzoeking, of om een zogenoemde inkijkoperatie uit te voeren. ${ }^{172}$ De bevoegdheid tot het betreden van plaatsen wordt in dat verband wel betiteld als een 'steundwangmiddel'. ${ }^{173}$

In het wetboek wordt onderscheid gemaakt tussen woningen, kantoren van verschoningsgerechtigden en overige plaatsen. Voor het betreden van de twee eerste categorieën locaties gelden strengere voorwaarden dan voor de laatste categorie. Dit betekent dat bedrijfsterreinen en bedrijfsgebouwen voor opsporingsambtenaren relatief gemakkelijk toegankelijk zijn. Ingeval van ontdekking op heterdaad of ingeval van een verdenking betreffende een misdrijf waarvoor voorlopige hechtenis is toegestaan, kan elke opsporingsambtenaar zich toegang verschaffen tot 'business premises' met het oog op de inbeslagneming van voorwerpen. ${ }^{174} \mathrm{Hij}$ behoeft daarvoor geen machtiging van een hiërarchisch hogere autoriteit en de voornaamste beperking van deze bevoegdheid is gelegen in de verdenkingsvoorwaarde.

\section{Wet op de economische delicten}

In de bijzondere strafwetgeving geldt de bevoegdheid tot het betreden van plaatsen als een zelfstandig dwangmiddel, dat als zodanig breed inzetbaar is. Weliswaar zal ook hier de uitoefening van de bevoegdheid vaak mede in dienst staan van andere bevoegdheden, maar het belang kan ook gelegen zijn in 'rondneuzen' op het bedrijf van de rechtspersoon: het inspecteren van de fysieke bedrijfsinrichting en -omgeving, het zoekend rondkijken binnen de bedrijfsruimten ${ }^{175}$, het op beelddragers vastleggen van hetgeen wordt bezichtigd en het stellen van vragen aan aanwezige werknemers. ${ }^{176}$ In haar zelfstandige vorm lijkt deze bevoegdheid dan sterk op het dwangmiddel van de schouw, dat in het Wetboek van Strafvordering slechts aan de (hulp)officier van justitie is toegekend. ${ }^{177}$

I72 Zie respectievelijk de artikelen 55, 96 e.v. en $\mathrm{I} 26 \mathrm{k} \mathrm{Sv}$.

I73 Aldus G.J.M. Corstens, Het Nederlands strafprocesrecht, 8 e druk, bewerkt door M.J. Borgers, Deventer 20I4, p. 584. Zie ook J. Claessen en D. de Vocht, 'De regeling inzake het betreden en doorzoeken van plaatsen en woningen verduidelijkt', AA 2012, p. 317-323.

I74 Zie art. 96 lid I Sv.

I75 Bij dat zoekend rondkijken mogen de opsporingsambtenaren zich binnen de bedrijfsruimte doorgang verschaffen door het openen c.q. forceren van toegangsdeuren en het verplaatsen van dozen. Zie o.a. HR I8 november 2003, NJ 2007, 8 en HR 2I oktober 2003, NJ 2007, 9, m.nt. P.A.M. Mevis. Zie voorts HR I8 maart 20I4, NJ 20I4, I89, waarin opsporingsambtenaren (na te zijn binnengetreden in een bedrijfshal) een roldeur openden teneinde een daarachter gelegen koelruimte te betreden.

I76 Zie D.V.A. Brouwer, Dwangmiddelen in bijzondere wetten, diss. Groningen, Deventer I999, p. 220. Het doel van het betreden in artikel 20 WED is geenszins beperkt tot inbeslagneming op grond van artikel I8 WED, zoals Claessen en De Vocht suggereren (a.w., p. 322).

I77 Zie art. I5I Sv, dat tevens voorziet in een voorafgaande schriftelijke kennisgeving aan en een aanwezigheidsrecht voor de verdachte en zijn raadsman. 
Op het terrein van het ondernemingsstrafrecht is vooral artikel 20 WED van belang. Deze bepaling luidt als volgt:

'De opsporingsambtenaren hebben in het belang van de opsporing toegang tot elke plaats, voor zover dat redelijkerwijs voor de vervulling van hun taak nodig is.'

Waar de bevoegdheid zich uitstrekt tot elke plaats, kunnen ook woningen worden betreden. Voor dat geval gelden echter de voorschriften van de Algemene wet op het binnentreden, op grond waarvan in beginsel een voorafgaande schriftelijke machtiging is vereist, af te geven door een (hulp)officier van justitie of een advocaat-generaal. Voor zover het gaat om bedrijfsgebouwen die niet als woning kunnen worden aangemerkt, gelden zulke voorschriften niet, althans niet zolang het begrip woning in de Algemene wet op het binnentreden beperkter wordt uitgelegd dan het begrip 'home' in artikel 8 EVRM. ${ }^{178}$

De zojuist geciteerde wettekst stelt weinig grenzen aan de uitoefening van de bevoegdheid. Zij zal kunnen worden ingezet met het oog op de opsporing van elk denkbaar economisch delict. Gegeven het feit dat de Nederlandse wetgeving vele duizenden economische delicten telt, verspreid over ruim honderd wetten en honderden lagere regelingen, variërend van zeer lichte overtredingen tot serieuze misdrijven, is wel duidelijk dat de reikwijdte van deze bevoegdheid groot is. Daar komt bij dat op het terrein van de WED een verruimd opsporingsbegrip wordt gehanteerd, hetgeen betekent dat de opsporingsbevoegdheden uit deze wet reeds mogen worden ingezet zodra 'aanwijzingen' bestaan dat op een bepaald terrein van werkzaamheid de voorschriften niet worden nageleefd. Er hoeft dan nog geen sprake te zijn van een concrete verdenking, in de zin van een redelijk vermoeden van schuld aan enig strafbaar feit. ${ }^{179}$

De wettekst brengt nog wel tot uitdrukking dat de opsporingsambtenaren de beginselen van subsidiariteit en proportionaliteit in acht zullen moeten nemen, maar de toegevoegde waarde daarvan is op zichzelf niet heel groot. Ook indien dat niet in de wet zou zijn vastgelegd, zou dat immers al gelden. ${ }^{180}$

I78 Vgl. HR 3 oktober I995, NJ I996, 219, m.nt. G. Knigge. Volgens P.A.M. Mevis, T\&C Strafuordering, $\mathrm{II}^{\mathrm{e}}$ druk, Deventer 20I5, aant. 5 a bij de Awbi, dwingt niets ertoe de interpretatie van het begrip 'woning' te verruimen tot bedrijfsruimten, zoals het EHRM in de context van het begrip 'home' heeft gedaan. Daar kan tegenover worden gesteld dat ook niets ertoe dwingt de interpretatie zo beperkt te houden als tot op heden is geschied. Met behulp van een dynamische interpretatie van het begrip 'woning' in de Awbi zou de rechtsbescherming van de verdachte rechtspersoon eenvoudig op hetzelfde niveau kunnen worden gebracht als die van de verdachte natuurlijke persoon.

I79 Zie o.a. HR 25 juni 20I3, NJ 20I4, I0, m.nt. J.M. Reijntjes en HR I8 maart 20I4, NJ 20I4, I89. In de laatste zaak werd op grond van artikel 20 WED binnengetreden in een bedrijfshal op basis van een anonieme melding. Uit de rechtspraak blijkt dat in een anonieme tip of CIE-informatie vaak al voldoende aanwijzingen worden gevonden om de inzet van WED-bevoegdheden te kunnen legitimeren. Zie D.R. Doorenbos, Schets van het economisch strafrecht, $8^{e}$ druk, Deventer 20I5, p. I2I-I23.

I80 Zie HR I2 december I978, NJ I979, I42, m.nt. G.E. Mulder. Vgl. voorts H.M.J. Quaedvlieg, 'Stés Colas: bouwstenen voor een stevige rechtsbescherming', Tijdschrift voor Onderneming en Strafrecht 2003, nr 3, p. 84-9I, op p. 90: 'Beperkingen als "te allen tijde”, "in het belang van de opsporing”, "redelijkerwijze noodzakelijk voor de vervulling van de taak" of vergelijkbare zinsneden, zijn geen beperkingen of verdienen althans deze benaming niet. Van enige wezenlijke inhoudelijke normering is in deze bepalingen geen sprake.' 


\section{I4 Rechterlijke toetsing}

De WED laat de opsporingsambtenaren in feite geheel vrij in het naar eigen goeddunken betreden van bedrijfsterreinen en bedrijfsgebouwen. Zoals gezegd wordt in artikel 20 WED geen onderscheid gemaakt naar delicten, terwijl een minimale graad van verdenking volstaat en voor de betrokken rechtspersoon niet is voorzien in procedurele waarborgen.

In de zaak Colas Est viel het EHRM vooral over de zeer ruim geformuleerde bevoegdheden van de onderzoekende autoriteit om geheel zelfstandig te bepalen of een bedrijfsbezoek opportuun zou zijn en hoe ver dat bedrijfsbezoek zou kunnen gaan. Aan het ontbreken van een voorafgaande rechterlijke toets werd daarbij veel gewicht toegekend.

Het is dan ook niet verwonderlijk dat vraagtekens zijn geplaatst bij het uiterlijk gemak waarmee opsporingsambtenaren in Nederland bedrijfsterreinen en bedrijfsgebouwen kunnen betreden. Zou de bevoegdheid tot binnentreden in een bedrijfsruimte ook hier te lande niet onderworpen behoren te zijn aan voorafgaand rechterlijk toezicht?

Diverse auteurs hebben die vraag bevestigend beantwoord en gepleit voor nadere wettelijke voorzieningen. ${ }^{181}$ De wetgever zou voor het betreden van bedrijfsgebouwen zonder toestemming van de rechthebbende een voorafgaande rechterlijke machtiging kunnen eisen of ten minste het regime van de Algemene wet op het binnentreden van toepassing kunnen verklaren op bedrijfsgebouwen. De Nederlandse wetgever heeft tot op heden echter (nog) geen aanleiding gezien om de toepassingsvoorwaarden voor het betreden van bedrijfsgebouwen aan te scherpen.

Erkend moet worden dat de rechtspraak van het EHRM leert dat het ontbreken van een voorafgaande rechterlijke machtiging voor een onvrijwillig bedrijfsbezoek niet per definitie 'fataal' zal hoeven zijn. Het Hof ziet in deze omstandigheid echter wel aanleiding voor een extra kritische toetsing van het inbreukmakende overheidsoptreden. ${ }^{182}$ Het ontbreken van een rechterlijke toetsing vooraf, kan op zichzelf worden gecompenseerd door een rechterlijke controle ex post facto, mits deze controle dan wel effectief kan worden geacht. Binnen het kader van het tweede lid van artikel 8 EVRM zal dan een volledige toetsing moeten plaatsvinden op zowel de feitelijke als de juridische aspecten van het ter discussie gestelde overheidsoptreden. Mocht blijken dat de inbreuk deze toets niet kan doorstaan, dan zal een passende compensatie mogelijk moeten zijn. ${ }^{183}$

I8I Overigens vaak mede in relatie tot het betreden van bedrijfsruimtes door toezichthouders op grond van art. 5:I5 Awb of bijzondere wetten. Zie o.a. T. Barkhuysen, 'Het betreden van bedrijfsruimten aan banden gelegd op grond van art. 8 EVRM?’, NTB 2002/8, p. 236-24I; H.M.J. Quaedvlieg, 'Stés Colas: bouwstenen voor een stevige rechtsbescherming', Tijdschrift voor Onderneming en Strafrecht 2003, nr. 3, p. 84-9I; A.J.P. Schild, De invloed van het EVRM op het Ondernemingsrecht, diss. Leiden, Deventer 20I2, p. 27I-272; M.M. Slotboom, 'De NMa staat voor de deur. Maar waar is haar rechterlijke machtiging? Tien jaar na Colas Est', M\&M 20I2, p. IIO-II6.

I82 Zie m.n. EHRM 2 oktober 2014 (Delta Pekárny AS), AB 2015, 29, m.nt. T. Barkhuysen en M.L. van Emmerik. Ingeval het nationale recht de autoriteiten toestaat een zoeking te verrichten zonder rechterlijke machtiging 'la Cour doit redoubler de vigilance' (par. 83).

I83 Zie ook EHRM 5 mei 20 I (Société Métallurgique Liotard Frères), AB 20I2, 32, m.nt. T. Barkhuysen en M.L. van Emmerik (par. I8). 
De eis van een effectieve rechterlijke controle op doorzoekingen kan overigens mede worden gebaseerd op artikel 6 EVRM als element van een fair trial. ${ }^{184}$ Zodoende kan het inbreukmakende optreden langs verschillende wegen worden beoordeeld op verenigbaarheid met de verdragsrechtelijk gewaarborgde rechten.

Bij de toetsing binnen het kader van artikel 8 lid 2 EVRM zal allereerst de vraag moeten worden gesteld of het overheidsoptreden 'bij de wet voorzien' was. Waar het gaat om de toegankelijkheid van de regeling lijkt dat wel in orde, maar tegelijkertijd kan wel worden vastgesteld dat de voorzienbaarheid daarvan te wensen overlaat. De discretionaire ruimte van de opsporingsambtenaren wordt in artikel 20 WED immers niet wezenlijk geclausuleerd, terwijl de rechtspraak die ruimte eerder heeft vergroot dan verkleind, gezien de uitleg van de woorden 'in het belang van de opsporing' als betrekking hebbende op 'aanwijzingen' in plaats van een redelijk vermoeden van schuld.

De vraag of het optreden een legitiem belang kon dienen zal in beginsel bevestigend kunnen worden beantwoord.

Over de vraag of het optreden in een democratische samenleving noodzakelijk was, kan vervolgens stevig worden gediscussieerd. Wat was de aanleiding voor de bevoegdheidstoepassing? Wat was de aard en inhoud van de verdenking respectievelijk wat waren de 'aanwijzingen' die de opsporingsambtenaren tot hun optreden brachten? Hoe aannemelijk was een en ander ten tijde van de beslissing tot het optreden? In hoeverre was de bevoegdheidstoepassing opportuun te achten? Stond er geen minder ingrijpend middel ter beschikking? Was de reikwijdte van de bevoegdheidstoepassing behoorlijk afgebakend? Stonden de duur, omvang en diepgang van de bevoegdheidstoepassing in redelijke verhouding tot het doel daarvan? Was voorzien in procedurele waarborgen om te voorkómen dat geprivilegieerde gegevens zouden worden ingezien of meegenomen? Is voldoende rekening gehouden met de mogelijke repercussies op de reputatie van de betrokken rechtspersoon? Uit de rechtspraak van het EHRM valt af te leiden dat al dergelijke vragen relevant zijn en dat het Hof hier een zeer indringende toetsing voorstaat. ${ }^{185}$

Die toetsing moet in Nederland dus nog steeds ex post facto plaatsvinden. ${ }^{\mathrm{I} 66} \mathrm{De}$ rechtspersoon die meent dat opsporingsambtenaren ten onrechte inbreuk hebben gemaakt op zijn recht op respect voor zijn 'business premises' als bedoeld in artikel 8 EVRM, vindt in de WED en in het Wetboek van Strafvordering geen afzonderlijke rechtsgang. Indien bij gelegenheid van het binnentreden iets in beslag is genomen,

I84 Zie o.a. EHRM 2I december 2010 (Société Canal Plus e.a.), Appl. nr 29408/o8; EHRM 2I december 2010 (Compagnie des Gaz de Pétrole Primagaz), Appl. nr 296r3/08; EHRM 5 mei 20II (Société Métallurgique Liotard Frères), $A B$ 20I2, 32, m.nt. T. Barkhuysen en M.L. van Emmerik; EHRM 2 april 2015 (Vinci Construction et GTM Génie Civil et Services), Appl. nrs 63629/10 en 60567/10.

I85 Zie bijvoorbeeld EHRM II oktober 2005 (Kent Pharmaceuticals Ltd), Appl. nr 9355/03: 'The criteria the Court has taken into consideration (...) include the severity of the offence in connection with which the search and seizure was effected, the manner and circumstances in which the order was issued, in particular the availability at that time of other evidence available at that time, the content and scope of the order, having particular regard to the nature of the premises searched and the safeguards taken in order to confine the impact of the measure to reasonable bounds, and the extent of possible repercussions on the reputation of the person affected by the search.'

I86 Nederland behoort op dit punt tot een minderheid van Europese landen waar voor het binnentreden in bedrijfsgebouwen (zonder toestemming van de betrokken onderneming) geen voorafgaande rechterlijke machtiging wordt vereist. Zie M.M. Slotboom, a.w., p. II6, alsmede EHRM 2 oktober 2014 (Delta Pekárny AS), par. 57. 
kan de rechtspersoon de (on)toelaatbaarheid van de inbreuk wel op indirecte wijze laten toetsen door in een beklagprocedure bij de raadkamer te klagen over de (on)rechtmatigheid van de inbeslagneming. De stelling zou dan moeten zijn dat de inbeslagneming onrechtmatig is omdat zij voortbouwde op een onrechtmatig binnentreden. Is daarentegen bij gelegenheid van het binnentreden niets in beslag genomen maar zijn bijvoorbeeld wel gegevens en bescheiden ingezien en gekopieerd, zaken onderzocht, monsters genomen en werknemers gehoord, dan staat de rechtspersoon gedurende het voorbereidende onderzoek betrekkelijk machteloos. De (on)rechtmatigheid van het binnentreden kan dan pas tijdens een eventuele behandeling ter terechtzitting bij de strafrechter aan de kaak worden gesteld. ${ }^{187}$

Met dit al blijft het twijfelachtig of in het Nederlandse systeem wel adequate en toereikende rechtswaarborgen bestaan tegen misbruik of willekeurige toepassing van de zo ruim omschreven bevoegdheid van artikel 20 WED. ${ }^{188}$ Zoals eerder geconstateerd, kan slechts de verdachte rechtspersoon wiens zaak uiteindelijk daadwerkelijk aan de zittingsrechter wordt voorgelegd, aldaar een mogelijk ongerechtvaardigde inbreuk op zijn 'huisrecht' laten vaststellen. Dat is rijkelijk laat. ${ }^{189}$ Indien de rechter achteraf zou oordelen dat ten onrechte is binnengetreden, zal dat oordeel op zichzelf nog niet impliceren dat het bewijs dat bij gelegenheid van het onrechtmatig binnentreden is verzameld ook zal worden uitgesloten van gebruik. Daar zullen dan nog stevige discussies over moeten worden gevoerd.

Overigens moet nog worden opgemerkt dat een rechterlijke machtiging tot binnentreden niet impliceert dat de inbreuk op het huisrecht reeds daardoor zal zijn gelegitimeerd. Het is slechts een (belangrijke) waarborg tegen mogelijk misbruik. Uit de rechtspraak van het EHRM blijkt intussen dat ook een onderzoeksrechter de opsporingsambtenaren te veel ruimte kan verschaffen, terwijl vanzelfsprekend ook in de daadwerkelijke uitvoering van het onderzoek nog zodanig 'grof' te werk kan worden gegaan dat de inbreuk ontoelaatbaar is te achten. ${ }^{190}$

\section{I5 Doorzoeking van bedrijfsruimten}

In het voorgaande is de binnentredingsbevoegdheid centraal gesteld en werd nog geen afzonderlijke aandacht besteed aan de verdergaande bevoegdheid tot door-

I87 Het is theoretisch denkbaar een gang naar de civiele 'restrechter' te maken, door hangende het onderzoek een kort geding aan te spannen tegen de Staat der Nederlanden ter zake van onrechtmatig handelen. In praktisch opzicht zal de rechtspersoon daar echter bar weinig mee opschieten (het binnentreden kan niet worden teruggedraaid) terwijl het ook overigens een moeizame rechtsgang lijkt met veel kans op schadelijke publiciteit.

I88 Ook in algemene zin is niet duidelijk hoe de ruime bevoegdheid tot het binnentreden in bedrijfsruimtes zich verhoudt tot de EVRM-rechtspraak (o.a. A.N. Kesteloo, De rechtspersoon in het strafrecht, Deventer 20I3, p. II5) maar in relatie tot art. $20 \mathrm{WED}$ is dat relatief het meest problematisch gezien de vroegtijdige toepasselijkheid van de bevoegdheid bij het bestaan van 'aanwijzingen'.

I89 Mosterd na de maaltijd, aldus Dommering in punt 6 van zijn annotatie bij EHRM I6 april 2002 (Société Colas Est e.a.), NJ 2003, 452.

I9o Vgl. respectievelijk EHRM I8 april 2013 (Saint Paul Luxembourg SA), waarin het Hof oordeelde dat met een minder vergaande maatregel had behoren te worden volstaan dan de onderzoeksrechter had bevolen, alsmede EHRM I6 oktober 2007 (Wieser en Bicos Beteiligungen GmbH), Appl. nr 74336/oI, waarin het Hof oordeelde dat de wettelijke waarborgen rondom de uitvoering van het door de onderzoeksrechter bevolen onderzoek door de rechercheurs niet in acht waren genomen. 
zoeking van bedrijfsruimten. Opgemerkt kan worden dat de Nederlandse wetgeving ook voor dergelijke doorzoekingen geen rechterlijke machtiging voorschrijft, doch de officier van justitie aanwijst als de centrale autoriteit die daarover mag beslissen. ${ }^{\text {19r }} \mathrm{Bij}$ dringende noodzakelijkheid kan zelfs een hulpofficier deze bevoegdheid uitoefenen. ${ }^{\text {I92 }}$ Uiteraard is het ook dan de vraag of de rechtspersoon aldus in voorkomend geval wel afdoende rechtsbescherming wordt geboden tegen willekeurige inbreuken op de rechten die hij kan ontlenen aan artikel 8 EVRM. De discussie daarover zal niet wezenlijk anders liggen dan bij de reeds besproken binnentredingsbevoegdheid.

Gesteld kan worden dat met de beschikbaarheid van een pakket bevoegdheden dat bestaat uit de bevoegdheid tot binnentreden, het nemen van inzage, het maken van kopieën, het nemen van monsters en het in beslag nemen van voorwerpen c.q. het vorderen van de uitlevering daarvan, weinig behoefte zal bestaan aan de bevoegdheid tot doorzoeking. ${ }^{\mathrm{I} 3}$ Wat de toetsing aan artikel 8 EVRM betreft, zal de inbreuk op de daarin vervatte rechten vooral moeten worden beoordeeld naar de concrete aard en omvang. Een doorzoeking zal, als gericht en stelselmatig onderzoek, in voorkomend geval wellicht een ernstiger inbreuk impliceren dan de toepassing van het zojuist genoemde bevoegdhedenpakket, maar het verschil kan uiteindelijk ook zeer gering zijn. Er is daarom op voorhand geen reden de uitoefening van de binnentredingsbevoegdheid minder kritisch te toetsen dan de uitoefening van de doorzoekingsbevoegdheid. Ter illustratie zij in dit verband gewezen op de zaak-Delta Pekárny $\mathrm{AS}^{\text {194 }}$, waarin het ging om een bedrijfsbezoek waarbij inzage werd genomen in gegevens en uiteindelijk slechts een zevental documenten werd gekopieerd, terwijl de onderzoekers overigens niet de bevoegdheid hadden tot inbeslagneming over te gaan. Het onderzoek leek daarmee minder vergaand dan een doorzoeking, doch dat weerhield het EHRM er niet van het overheidsoptreden indringend te toetsen.

\section{$5 \quad$ Conclusies}

Wanneer de verdachte een rechtspersoon is, roept dat gegeven bijzondere vragen op die zich niet voordoen ingeval de verdachte 'gewoon' een mens is. Deze vragen komen voort uit de omstandigheid dat de rechtspersoon een juridische constructie is, een organisatie die zich gedraagt en zich uit door middel van de mensen die voor haar werkzaam zijn. De effectiviteit van de verdediging van die organisatie zal afhangen van de mate waarin haar mensen in staat zijn haar verdedigingsrechten uit te oefenen. Het recht zal de verdedigingsvrijheid van de rechtspersoon moeten waarborgen, met inachtneming van de eisen die voortvloeien uit het EVRM.

In de praktijk bestaat op veel onderdelen onvoldoende duidelijkheid omtrent de rechtspositie van de bestuurders en werknemers van de rechtspersoon indien deze rechtspersoon verdacht is en wordt geconfronteerd met strafrechtelijk onderzoek.

I9I Zie artikel 96a lid I Sv.

I92 Zie artikel 96a lid $2 \mathrm{~Sv}$.

I93 Zie ook hiervóór, onderdeel 4.I2.

I94 Zie EHRM 2 oktober 2014 (Delta Pekárny AS), AB 2015, 29, m.nt. T. Barkhuysen en M.L. van Emmerik. 
De wettelijke regeling inzake de vertegenwoordiging van de rechtspersoon in het strafproces is summier en geeft geen antwoord op de belangrijke vragen die in de opsporingsfase opkomen. Hoe kan de rechtspersoon in die eerste en vaak cruciale fase zijn zwijgrecht effectueren? Wie van zijn mensen zou dat kunnen doen? Wie van zijn mensen kan toestemming geven voor onderzoekshandelingen ten laste van de rechtspersoon? Kunnen zijn mensen nog worden verplicht tot medewerking aan het opsporingsonderzoek tegen de rechtspersoon? Kunnen zijn mensen nog worden verplicht tegen de rechtspersoon te getuigen? Het zijn vragen waarop de wet geen antwoord geeft, vragen waarover de literatuur verdeeld is en vragen waarover nog zeer weinig rechtspraak bestaat.

In dit preadvies zijn deze vragen besproken en op onderdelen voorzien van een voorlopige beantwoording, in het volle besef dat de opgeworpen vragen zeer uiteenlopend kunnen worden benaderd. Ten behoeve van verdere discussie besluit ik met een samenvatting van de belangrijkste standpunten die in dit preadvies zijn ingenomen:

- De verdachte rechtspersoon behoort volledig vrij te zijn in de keuze van zijn procesvertegenwoordiger(s) en behoort ook overigens vrij te zijn in de wijze waarop hij zijn werknemers instrueert omtrent het afleggen van verklaringen in het strafrechtelijk onderzoek.

- De bestuurders van een verdachte rechtspersoon dienen zowel in de opsporingsfase als in de vervolgingsfase te worden bejegend als vertegenwoordigers van de rechtspersoon, ongeacht de vraag wie van hen de rechtspersoon ter zitting zal vertegenwoordigen.

- De werknemers van een verdachte rechtspersoon die worden benaderd en gehoord als getuigen, behoren zich te kunnen beroepen op het zwijgrecht van de rechtspersoon en dienen daar voorafgaand aan een verhoor op te worden gewezen (afgeleid zwijgrecht en cautie).

- Uitsluitend de daartoe bevoegde vertegenwoordiger(s) van een verdachte rechtspersoon kunnen toestemming verlenen tot het verrichten van strafrechtelijk onderzoek dat inbreuk maakt op de rechten van de rechtspersoon en die toestemming kan dus niet worden verkregen van de gemiddelde werknemer.

- Indien de wet een verbod inhoudt om een verdachte tot medewerking te verplichten, behoort dat verbod ook te gelden in relatie tot de werknemers van de verdachte rechtspersoon.

- Het betreden van bedrijfsgebouwen is in de Nederlandse wetgeving op zo ruime schaal toegestaan dat het twijfelachtig is of de verdachte rechtspersoon in voorkomend geval de mate van rechtsbescherming kan worden geboden die op grond van het EVRM is vereist. 